\title{
Review of Nonconventional Bioreactor Technology
}

\author{
C. E. Turick \\ M. E. Mcllwain
}

Published September 1993

\section{Idaho National Engineering Laboratory \\ EG\&G Idaho, Inc. \\ Idaho Falls, Idaho 83415}




\begin{abstract}
Biotechnology will significantly affect many industrial sectors in the future. Industrial sectors that will be affected include pharmaceutical, chemical, fuel, agricultural, and environmental remediation. Future research is needed to improve bioprocessing efficiency and cost-effectiveness in order to compete with traditional technologies. This report describes recent advances in bioprocess technologies and bioreactor designs and relates them to problems encountered in many industrial bioprocessing operations. The primary focus is directed towards increasing gas and vapor transfer for enhanced bioprocess kinetics as well as improved by-product separation and removal. The advantages and disadvantages of various conceptual designs such as hollow-fiber, gas-phase, hyperbaric/hypobaric, and electrochemical bioreactors are also discussed. Specific applications that are intended for improved bioprocesses include coal desulfurization, coal liquefaction, soil bioremediation, biomass conversion to marketable chemicals, biomining, and biohydrometallurgy as well as bioprocessing of gases and vapors.
\end{abstract}




\section{CONTENTS}

REVIEW OF NONCONVENTIONAL BIOREACTOR TECHNOLOGY $\ldots \ldots \ldots \ldots \ldots \ldots \ldots$

GAS-LIQUID MASS TRANSFER IN BIOREACTORS $\ldots \ldots \ldots \ldots \ldots \ldots \ldots \ldots \ldots \ldots \ldots 2$

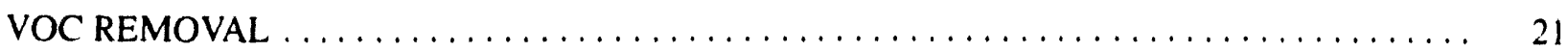

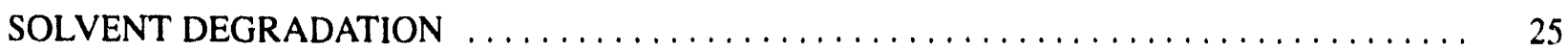

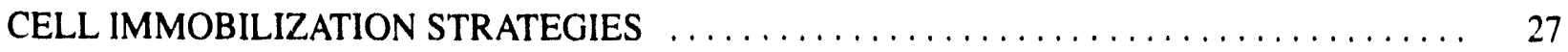

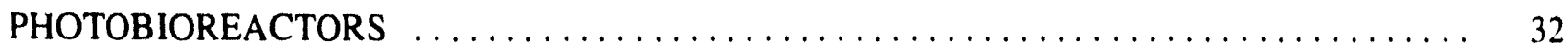

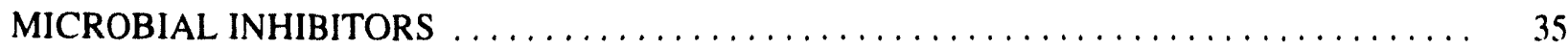

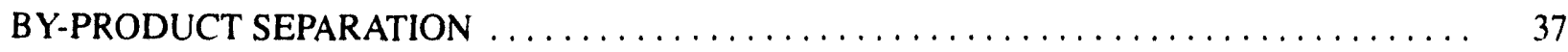

ELECTROCHEMICAL AND ELECTROLYTIC BIOREACTORS $\ldots \ldots \ldots \ldots \ldots \ldots \ldots \ldots$

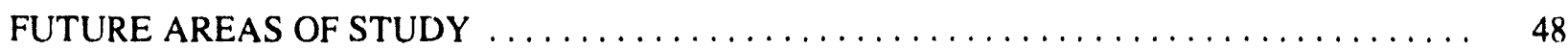

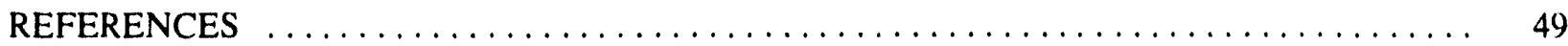

\section{FIGURES}

1. Schematic drawing of the experimental facility consisting of two identical units . . . . . . . 4

2. Schematic drawing for illustration of fluid motion in a volumetric element of the bioreactor . 5

3. Time course of MAb production with two impeller designs $\ldots \ldots \ldots \ldots \ldots \ldots \ldots \ldots \ldots$

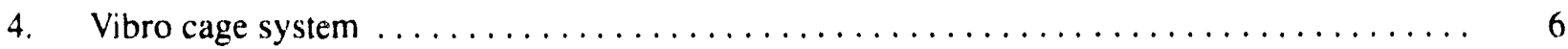

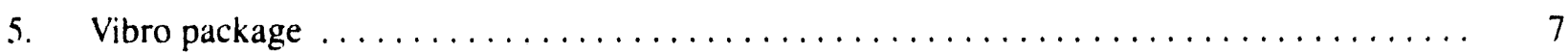

6. Effect of length of hollow fiber on oxygen transfer from silicone hollow fiber membrane to

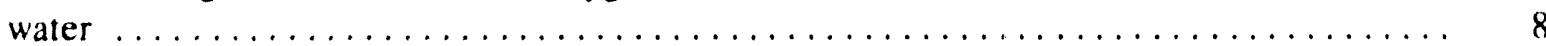

7. Cross-sectional view of the two bioreactor configurations $\ldots \ldots \ldots \ldots \ldots \ldots \ldots \ldots$

8. Cross-section showing the spherical geometry of the dimpled membrane $\ldots \ldots \ldots \ldots \ldots$

9. Schematic diagram of the experimental setup of airlift bioreactor with net draft tube $\ldots \ldots \quad 10$

10. Volumetric mass transfer coefficient with respect to superficial air velocity for different

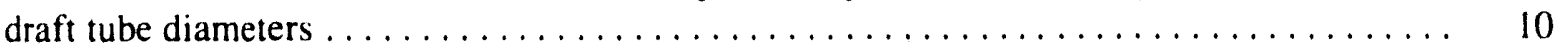

11. Schematic diagram of single-pass bioreactor $\ldots \ldots \ldots \ldots \ldots \ldots \ldots \ldots \ldots \ldots \ldots \ldots \ldots \ldots$

12. Comparison of antibody yield between the single-pass bioreactor and the recycle

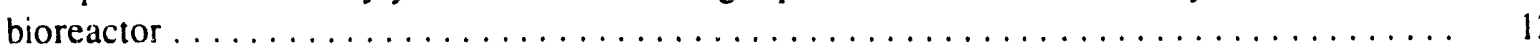


13. Cross-sectional view of single-pass bioreactor as formulated in the oxygen transport

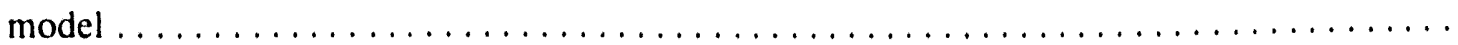

14. Growth of ES4 at $95^{\circ} \mathrm{C}$ and $500 \mathrm{~atm}$ in the hydrostatic vessel and the glass-lined

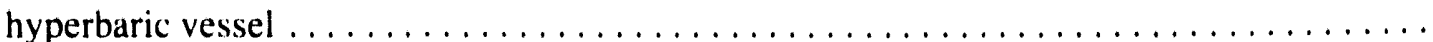

15. Schematic diagram of modified high-pressure system $\ldots \ldots \ldots \ldots \ldots \ldots \ldots \ldots \ldots \ldots$

16. Schematic of liquid-liquid spray column fermentor system $\ldots \ldots \ldots \ldots \ldots \ldots \ldots \ldots \ldots$

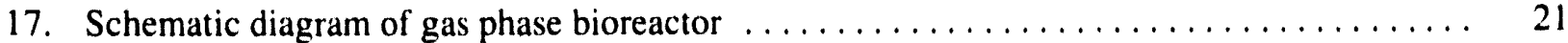

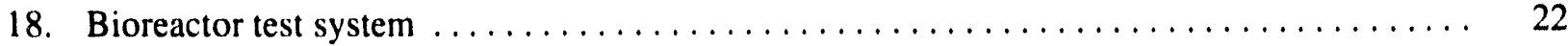

19. Schematic diagram of the laboratory-scale fabric biofilter system $\ldots \ldots \ldots \ldots \ldots \ldots \ldots \ldots$

20. Schematic of sequencing reactor during growth mode $\ldots \ldots \ldots \ldots \ldots \ldots \ldots \ldots \ldots \ldots$

21. Schematic of sequencing reactor during degradation mode $\ldots \ldots \ldots \ldots \ldots \ldots \ldots \ldots \ldots$

22. Experimental packed bed bioreactor apparatus $\ldots \ldots \ldots \ldots \ldots \ldots \ldots \ldots \ldots \ldots \ldots \ldots$

23. Ceramic microfilter reactor in dead-end configuration under batch-recycle operation $\ldots \ldots .30$

24. The gel membrane reactor $\ldots \ldots \ldots \ldots \ldots \ldots \ldots \ldots \ldots \ldots \ldots \ldots \ldots \ldots \ldots \ldots \ldots \ldots \ldots$

25. Bioreactor tilted at an optimum angle to increase solar radiation, photosynthesis rates,

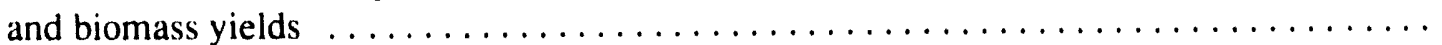

26. Schematic diagram of the light diffusing optical fiber photobioreactor system showing the ceramic membrane filtration module used for removing medium $\ldots \ldots \ldots \ldots \ldots \ldots$

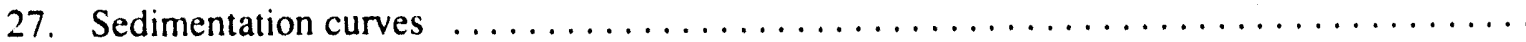

28. Schematic diagram of the apparatus used for solar hydrogen generation using Halobacterium halobium $\mathrm{MMT}_{22}$ and a silicon cell $\ldots \ldots \ldots \ldots \ldots \ldots \ldots \ldots \ldots \ldots \ldots, \ldots \ldots$

29. Selectivity of the tyrosinase-catalyzed reaction for phenols $\ldots \ldots \ldots \ldots \ldots \ldots \ldots \ldots \ldots$

30. Integrated butanol production processes. Schematic of a fluidized bed reactor . . . . . . . 37

31. Schematic of a stripping process for in-situ butanol recovery $\ldots \ldots \ldots \ldots \ldots \ldots \ldots \ldots$

32. Schematic of an adsorption process for in-situ butanol recovery $\ldots \ldots \ldots \ldots \ldots \ldots \ldots \ldots$

33. Schematic of a liquid-liquid extraction process for in-situ butanol recovery $\ldots \ldots \ldots \ldots \ldots$

34. Schematic of a pervaporation process for in-situ butanol recovery $\ldots \ldots \ldots \ldots \ldots \ldots \ldots$

35. Schematic of a membrane solvent extraction process for in-situ butanol recovery $\ldots \ldots \ldots . \quad 39$

36. Concentration profiles in the biofilm $\ldots \ldots \ldots \ldots \ldots \ldots \ldots \ldots \ldots \ldots \ldots \ldots \ldots \ldots \ldots \ldots \ldots$ 
37. Schematic of experimental biparticle fluidized-bed bioreactor operating in the countercurrent mode $\ldots \ldots \ldots \ldots \ldots \ldots \ldots \ldots \ldots \ldots \ldots \ldots \ldots \ldots \ldots \ldots \ldots \ldots$

38. Schematic diagram of apparatus for pervaporation by hollow-fiber module $\ldots \ldots \ldots \ldots \ldots 42$

39. Relation between mole fraction of butanol in feed solution and that in permeate solution $\ldots . .42$

40. Schematic description of the coupled system $\ldots \ldots \ldots \ldots \ldots \ldots \ldots \ldots \ldots \ldots \ldots \ldots \ldots$

41. Schematic diagram of integrated continuous fermentation/product removal for $A B E$

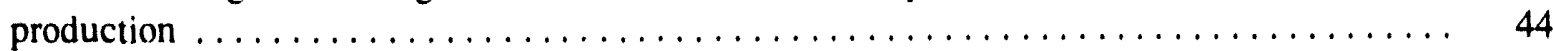

42. Example of multilayer membrane bioreactor $\ldots \ldots \ldots \ldots \ldots \ldots \ldots \ldots \ldots \ldots \ldots \ldots, 45$

43. Schematic diagram of system for ED-F with an MF module $\ldots \ldots \ldots \ldots \ldots \ldots \ldots \ldots .45$

44. Cyclic voltammogram of electrochemical oxidation of NADH in an electrochemical

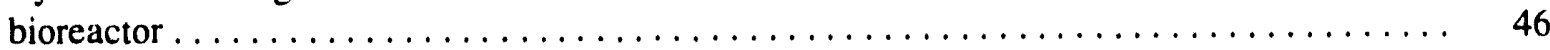

45. G6PDH reaction conjugated with constant potential $\ldots \ldots \ldots \ldots \ldots \ldots \ldots \ldots \ldots \ldots$

46. NAD regeneration system by G6PDH in an electrochemical bioreactor $\ldots \ldots \ldots \ldots \ldots$

\section{TABLES}

1. Typical properties of fluorocarbons $\ldots \ldots \ldots \ldots \ldots \ldots \ldots \ldots \ldots \ldots \ldots \ldots \ldots$

2. Properties of unwoven fibrous packing materials used in bioreactors $\ldots \ldots \ldots \ldots \ldots \ldots \ldots$

3. Maximum removal rates of DMS in different fabric biofilters $\ldots \ldots \ldots \ldots \ldots \ldots \ldots \ldots$

4. Compositions of media used for bacterial countings $\ldots \ldots \ldots \ldots \ldots \ldots \ldots \ldots \ldots \ldots$

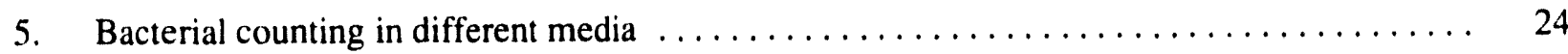

6. Methane fermentation from formate in fixed-bed reactor $\ldots \ldots \ldots \ldots \ldots \ldots \ldots \ldots$

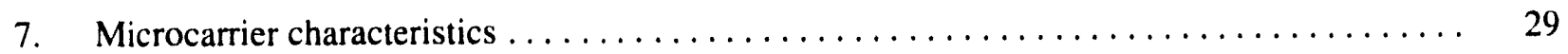

8. Average pseudo-steady-state reactor performance at an organic loading of $6 \mathrm{~g} \ldots \ldots \ldots \ldots$

9. Permeability of phenol through commercial membrane $\ldots \ldots \ldots \ldots \ldots \ldots \ldots \ldots \ldots$ 


\section{REVIEW OF NONCONVENTIONAL BIOREACTOR TECHNOLOGY}

Advances in biotechnology within the past decade have placed this field at the center of attention from both an economic and scientific perspective. Biotechnology has significant potential to positively affect numerous industrial sectors, including:

- Pharmaceutical

- Chemical

- Fuel

- Agricultural

- Environmental remediation

- Pollution control technologies.

The economic feasibility of many biotechnologies is largely dependent on efficient and cost-effective bioprocesses. To surpass or at least compete with traditional technologies, many bioprocesses will need to demonstrate consistent and practical operations.

The purpose of this review is to present information concerning recent advances in bioprocess technologies and relate them to current problems encountered in many industrial bioprocessing endeavors. Areas of interest that pertain to this review are high solids bioprocessing such as:

- Coal desulfurization

- Coal liquefaction

- Contaminated soil bioremediation
- Biomass conversion to marketable chemicals

- Biomining

- Biohydrometallurgy.

Another aspect of biotechnology of interest is that of bioprocessing of gases and vapors. Specific examples include synthesis and combustion gases such as volatile organic carbon (VOC), $\mathrm{CO}$, $\mathrm{CH}_{4}, \mathrm{CO}_{2}, \mathrm{H}_{2}$, and $\mathrm{NO}_{\mathrm{X}}$. Since VOC is a very broad term, this particular group of chemicals is also associated with environmental contamination by gasoline, diesel fuel, and chlorinated hydrocarbons.

Problems encountered in bioprocessing of the above mentioned substrates include:

- Increasing mass transfer of gaseous compounds introduced into a bioreactor

- Minimizing imbalanced conditions

- Product separation

- Maintaining the desired population of cells within the bioreactor

- Optimizing light penetration for photosynthetic organisms.

This review will address each of these topics and more recent technological advances that attempt to solve common problems of industrial bioprocessing and bioreactor design. 


\section{GAS-LIQUID MASS TRANSFER IN BIOREACTORS}

Bioprocesses involving the use of gases must be designed to optimize the mass transfer of the gas or gases from the gas phase to the liquid phase via the gas-liquid interface and allow the gas to diffuse through the culture medium and to the cell surface where transport into the cell takes place. Because of the low solubility of many gases used in biotechnology, gas mass transfer is often the rate limiting step. The primary resistance to gas mass transfer may be assumed to be in the liquid film at the gas-liquid interface for sparingly soluble gases and can be described by the equation:

$$
\text { moles transported }=\frac{K_{L} a}{H\left(P^{G}-P^{L}\right)}
$$

where

$$
\begin{aligned}
\mathrm{K}_{\mathrm{L}} \mathrm{a}= & \begin{array}{l}
\text { overall gas mass transfer coeffi- } \\
\text { cient }
\end{array} \\
\mathrm{H} & =\text { Henry's law constant } \\
\mathrm{PG}= & \begin{array}{l}
\text { substrate partial pressure in gas } \\
\text { phase }
\end{array} \\
\mathrm{PL}= & \begin{array}{l}
\text { substrate partial pressure at equi- } \\
\text { librium with the substrate con- } \\
\text { centration in the bulk liquid } \\
\text { phase. }
\end{array}
\end{aligned}
$$

Cells in the liquid phase consume the substrate at a maximum rate of:

moles consumed $=q X V_{L}$

where

$$
\begin{aligned}
& \mathrm{q}=\text { specific uptake rate } \\
& \mathrm{X}=\text { cell density } \\
& \mathrm{V}_{\mathrm{L}}=\text { liquid volume. }
\end{aligned}
$$

A microbial culture growing in liquid medium not limited by gas mass transfer will be limited by microbial kinetics. Important design characteristics for a bioreactor include specific interfacial area, liquid retention, and mass transfer coefficients. Conventional bioreactors in common use are mechanically stirred tank bioreactors, bubble columns, and packed bed columns. Aerobic bioprocesses requiring oxygen as the only gas can be designed to be either batch or continuous operations. Bioreactors for the use of synthesis gas or combustion gases need to be continuous operations because of the large volume of gases encountered. ${ }^{\prime}$

Continuous systems that have demonstrated high mass transfer rates include constantly stirred tank reactors (CSTR), immobilized cell bioreactors (ICBs), and trickle bed bioreactors. CSTRs have been shown to have an $80 \%$ efficiency rate of synthesis gas conversion. ${ }^{2}$ Slightly soluble gases need rapid stirring rates in these bioreactors, which increases the operational costs. Assuming a CSTR has a low hydraulic and solids retention time, high microbial biomass can be achieved and maintained. This is necessary to maximize gas conversion kinetics and decrease gas retention time in the bioreactor. Since the bioreactor size is a direct function of microbial reaction rate and gas retention time, a CSTR has a volume limitation because of heating costs.

Immobilized cell bioreactors (ICBs) allow for high cell density and plug flow operation, which allows for high surface to volume ratios and high mass transfer rates. Klasson et al. ${ }^{2}$ have demonstrated higher efficiency of gas conversion with immobilized cell bioreactors than CSTRs. Because of the high cell density and no stirring requirements of ICBs, they are potentially more economically feasible to operate.

Trickle bed columns allow gas in the continuous phase to pass over microbial cells growing on a fixed surface with nutrients passing over the surface. In order to increase reaction rates in these bioreactors, the solid supports can be configured to increase surface area and allow for higher cell density. Nutrient flow can be eirher concurrent or countercurrent to the flow of gas.

Several nonconventional technologies have been employed recently to deal with gas mass 
transfer in bioreaclors. Brauer ${ }^{3}$ and Brauer and Annachhatre ${ }^{4}$ demonstrated the application of the reciprocating jet bioreactor in increasing mass transfer of oxygen to bacterial and fungal cultures. The design of this bioreactor system consists of two units with a reciprocating jet bioreactor (HR), which is a cylindrical glass vessel (GZ) (diameter/height ratio either 1:2 or 1:4), located in the heart of each unit (see Figure 1). The volume of the bioreactors is either $12.5 \mathrm{dm}^{3}$ or $20 \mathrm{dm}^{3}$. HS is the reciprocating axis of HR, on which a package of sieve plates (LS) is mounted. The reciprocating motion of this system is achieved by the electronic motor $(\mathrm{M})$ and a special crank gear $(\mathrm{KT})$. The reciprocating motion of this system can vary from $0.25-1.25 \mathrm{~Hz}$, while the amplitude remains constant at $100 \mathrm{~mm}$ (the optimum value).

The sieve plates are $50 \mathrm{~mm}$ apart, making the ratio of amplitude of the reciprocating motion and distance between plates 2 . The diameter of the holes in the sieve plates is $12 \mathrm{~mm}$, spaced $27 \mathrm{~mm}$ apart and arranged in the corners of a triangulum. with $11 \%$ making up the free area of the holes of the plate. Top and bottom lids (DP and BP) are stainless steel. DP contains openings for the reciprocating axis HS, for exit air (LA), substrate (SZ), inoculum (IZ), antifoam agent (AS), and for various instruments. Openings in the bottom lid are for air introduction (LZ), and biosuspension sampling (FP).

The bioreactor operates in a vertical reciprocating manner to allow fluid to flow through the holes in the plates, thus increasing turbulence and mixing of the cells, nutrients, and gases within the plates as well as among the plates. Both reciprocating jet bioreactors are operated independently of each other in alternating vertical motion, thereby maintaining the same total volume throughout the two systems (see Figure 2).

Oxygen transfer in the reciprocating jet bioreactor has been reported to be very efficient ${ }^{3.5}$ and can be correlated by the following equation:

$\frac{M_{o, \max }}{V=c(N / V)^{1 / 2}}$ where

$$
\begin{aligned}
M_{0, \max }= & \begin{array}{l}
\text { oxygen transfer rate for maxi- } \\
\text { mum gas flow rate (flow rate } \\
\text { just before dispersion of the air } \\
\text { breaks down and flooding of } \\
\text { the package plates begins) }
\end{array} \\
V \quad= & \text { bioreactor volume } \\
N \quad= & \begin{array}{l}
\text { input of mechanical energy per } \\
\text { unit of time. }
\end{array}
\end{aligned}
$$

The empirical constant $c=2.05$ for this bioreactor. The values for $c$ for turbine stirrers and bubble columns are 1.45 and 0.69 respectively, thereby demonstrating superior operation efficiency with a reciprocating jet bioreactor.

The equation above can be applied in the range

$\frac{1<M_{0, \max }}{N<6}$.

Since $\mathbf{N}$ is proportional to the third power of the frequency $f$, the oxygen transfer rate is given by the proportionality:

$M_{o, \max }$ is proportional to $f^{3 / 2}$.

Oxygen transfer increases with frequency but the energy requirement increases even more so.

Another way to express the rate of oxygen transfer is with the equation:

$M_{o, \max }=\beta a_{p} \Delta P o$

where

$B=$ time mean value of the mass transfer coefficient taken over time of half a cycle

$a_{p}=$ specific interfacial area

${ }_{\Delta} P_{0}=$ mean difference of oxygen concentration in the bulk of the fluid and in the interface of the bubble

$B a_{\mathrm{p}}=$ proportional to $f^{3 / 2}$. 


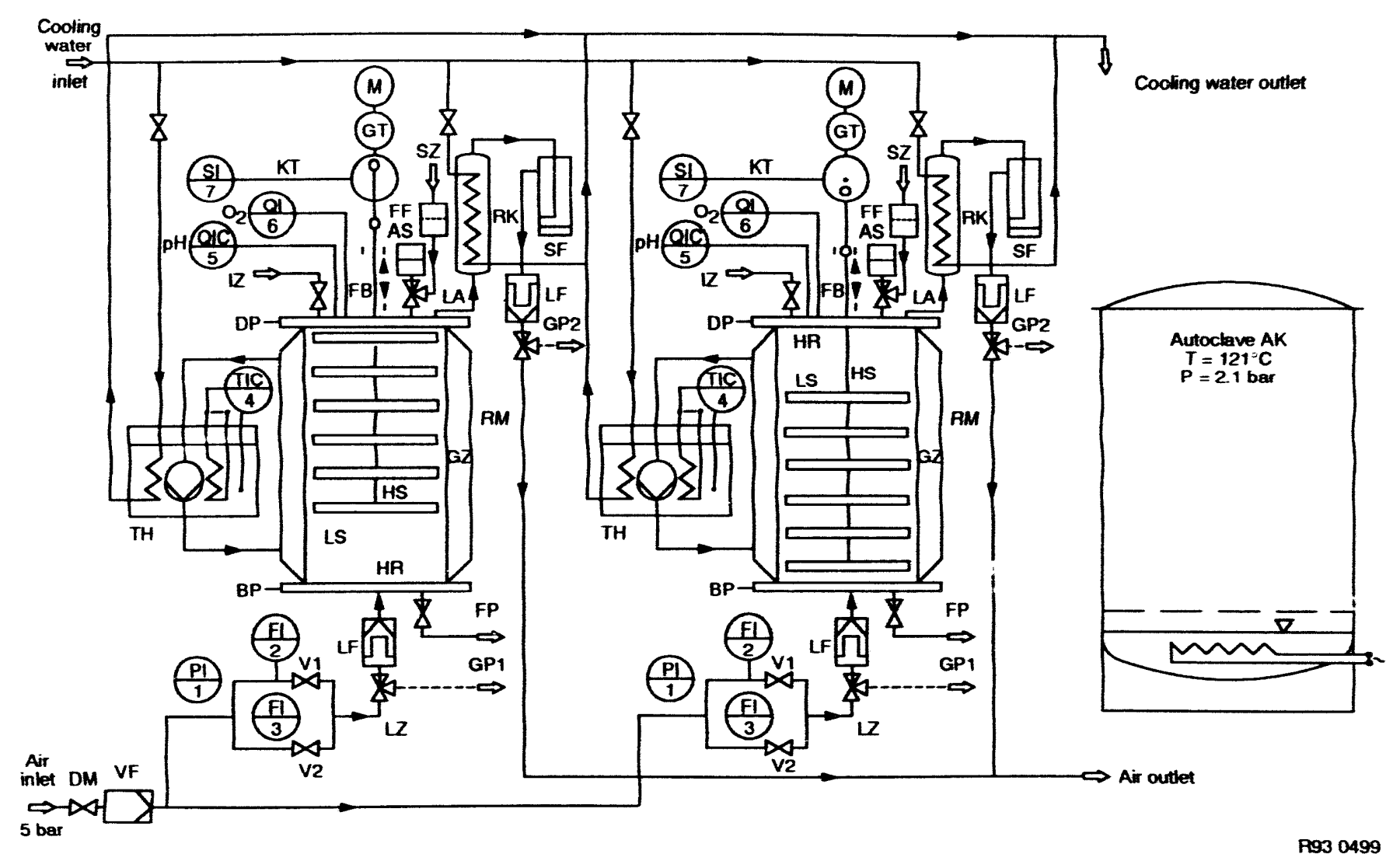

Figure 1. Schematic drawing of the experimental facility consisting of two identical units. 

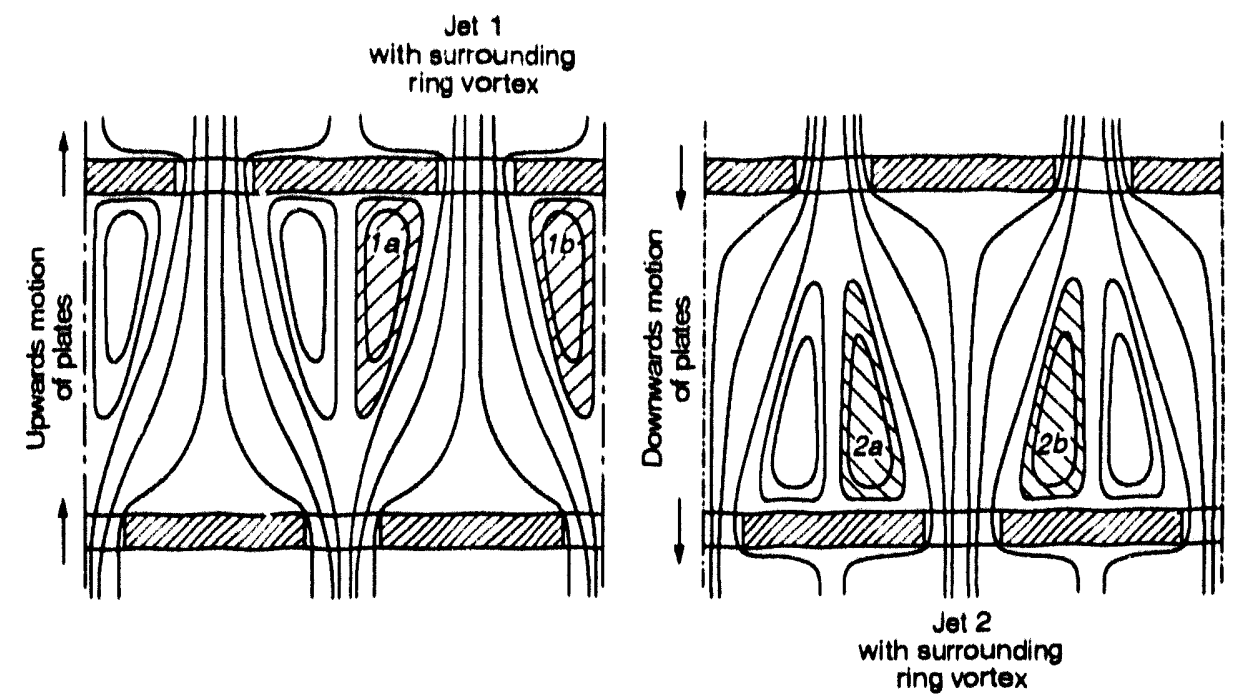

R93 0607

Figure 2. Schematic drawing for illustration of fluid motion in a volumetric element of the bioreactor.

Although faster agitation and stirring facilitate greater mixing and gas mass transfer, the costs involved can be prohibitive. Shear forces from violent mixing have been shown to damage cells and can also disrupt gel beads containing immobilized cells. Several methods have been developed to facilitate gas mass transfer while avoiding violent agitation. Shi et al. ${ }^{6}$ reported a new impeller design for mammalian cell culture using an annular cage impeller with an increased surface area that increases convective oxygen transfer and reduces hydrodynamic shear damage to the cells. This design increased the oxygen transfer rate, cell density, and product concentration in batch cultures. In this design, oxygen is transferred from an air bubble rising in the liquid medium where oxygen transfer occurs at the airliquid interface and bulk flow across the wire screen of the annular cage impeller. The oxygenated medium is then transported through the screen. The following equation gives the relationship between overall oxygen transfer resistance and the oxygen transfer resistances in the airliquid region and the liquid-wire screen region:

$$
\begin{aligned}
& \frac{1}{\left[V_{1}\left(\left(k_{L} a\right)_{T}-\left(k_{L} a\right)_{A}\right)\right]} \\
& \quad=\frac{1}{\left[V_{C}\left(k_{L} a\right)_{B}\right]}+\frac{1}{\left[\left(V_{1}-V_{C}\right)\left(K_{L} a\right)_{S}\right]}
\end{aligned}
$$

where

$$
\begin{aligned}
& \left(k_{L^{a}}\right)_{T}=\begin{array}{l}
\text { overall volumetric oxygen } \\
\text { transfer coefficient }
\end{array} \\
& \left(k_{L^{a}}\right)_{A}=\begin{array}{l}
\text { volumetric oxygen transfer } \\
\text { coefficient for surface aera- } \\
\text { tion }
\end{array} \\
& \left(k_{L^{a}}\right)_{B}=\begin{array}{l}
\text { air-liquid volumetric oxygen } \\
\text { coefficient inside the cage }
\end{array} \\
& \left(k_{L} a\right)_{S}=\begin{array}{l}
\text { liquid-wire screen volumetric } \\
\text { oxygen transfer coefficient }
\end{array} \\
& V_{1} \text { and } V_{c}=\begin{array}{l}
\text { bioreactor working volume } \\
\text { and the volume of the cage. }
\end{array}
\end{aligned}
$$

Figure 3 shows the improved monoclonal antibodies (MAb) production with this new impeller design with increased oxygen transfer rates.

Reiter et al. ${ }^{7}$ developed a method to allow for rapid mixing within the bioreactor for increased oxygen solubility wherc oxygen is dissolved in a liquid medium before :ontacting cells in microcarriers grown in a caged, vibrating growth chamber (see Figures 4 and 5 ). In this way immobilized cells are not damaged by hydrodynamic shear forces. The cage is vibrated at a minimum amplitude $(<0.3 \mathrm{~mm})$ and frequency $(50 \mathrm{~Hz})$ to prevent 


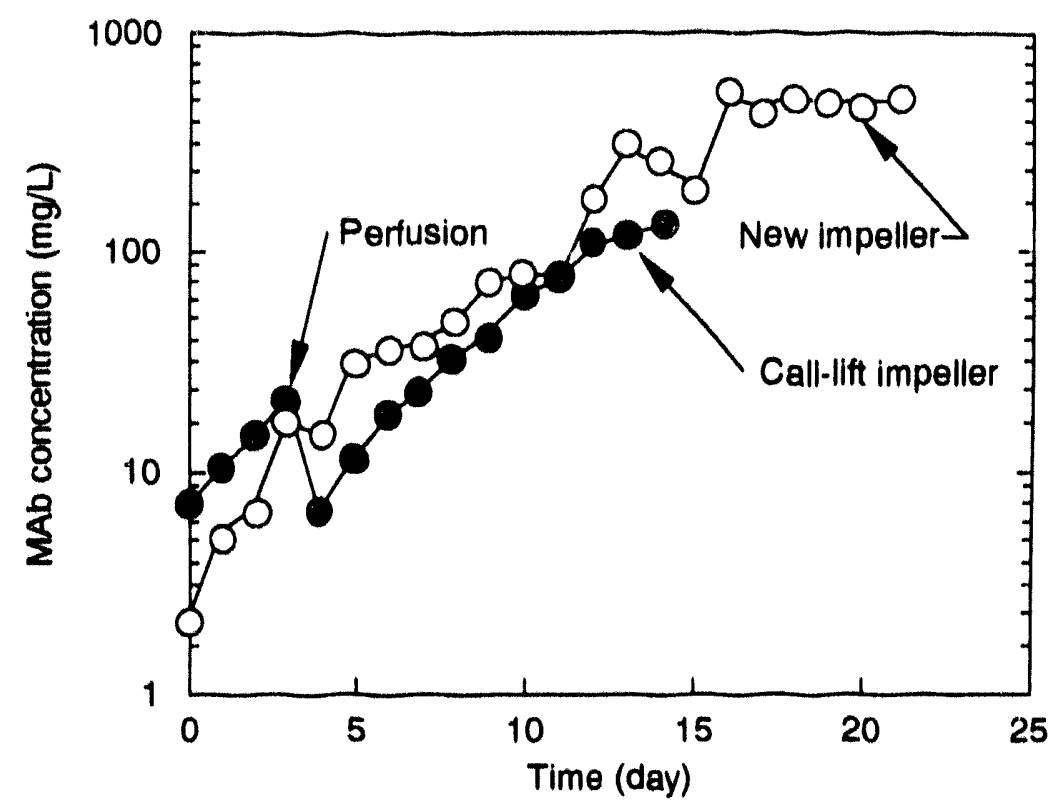

R93 0608

Figure 3. Time course of MAb production with two impeller designs.

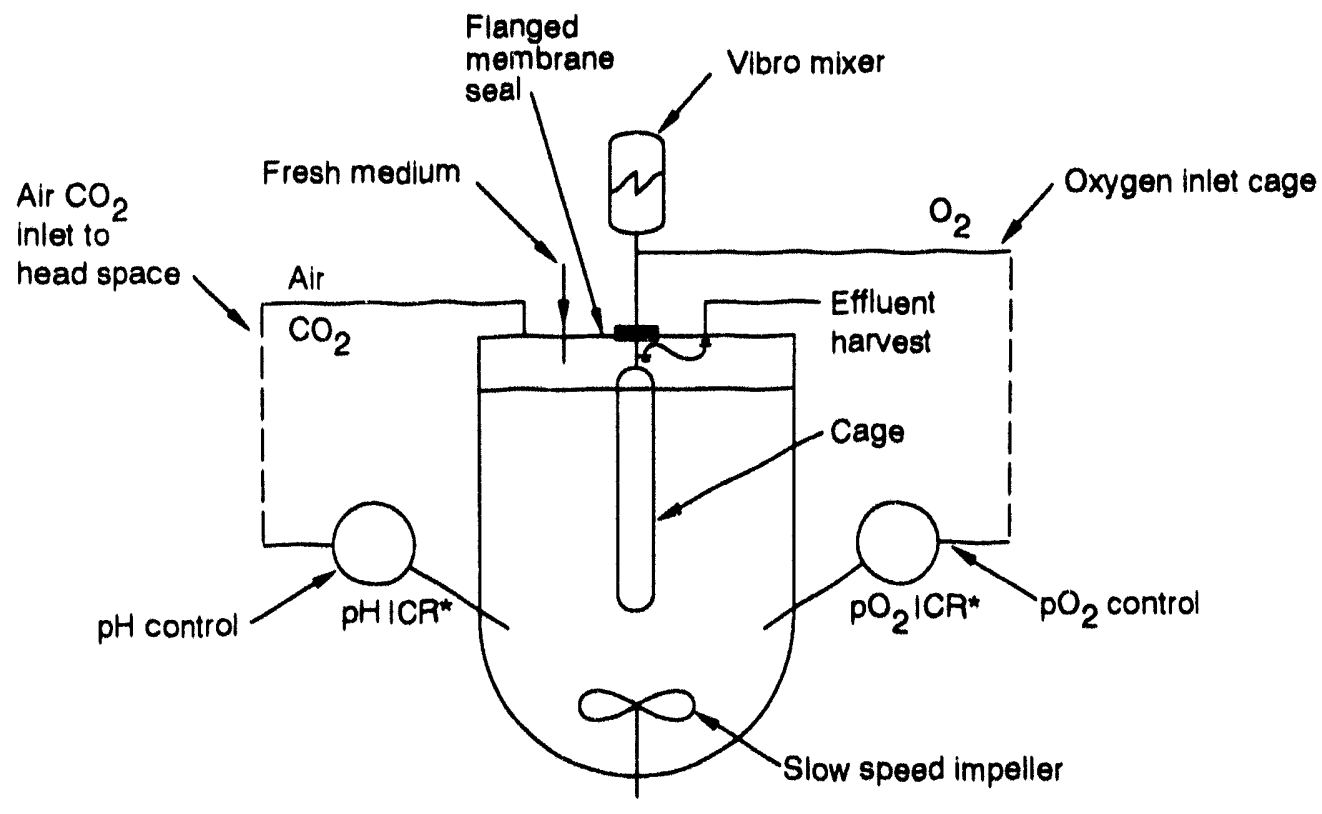

* ICR stands for Indicator Controller Registrations.

R93 0609

Figure 4. Vibro cage system. 


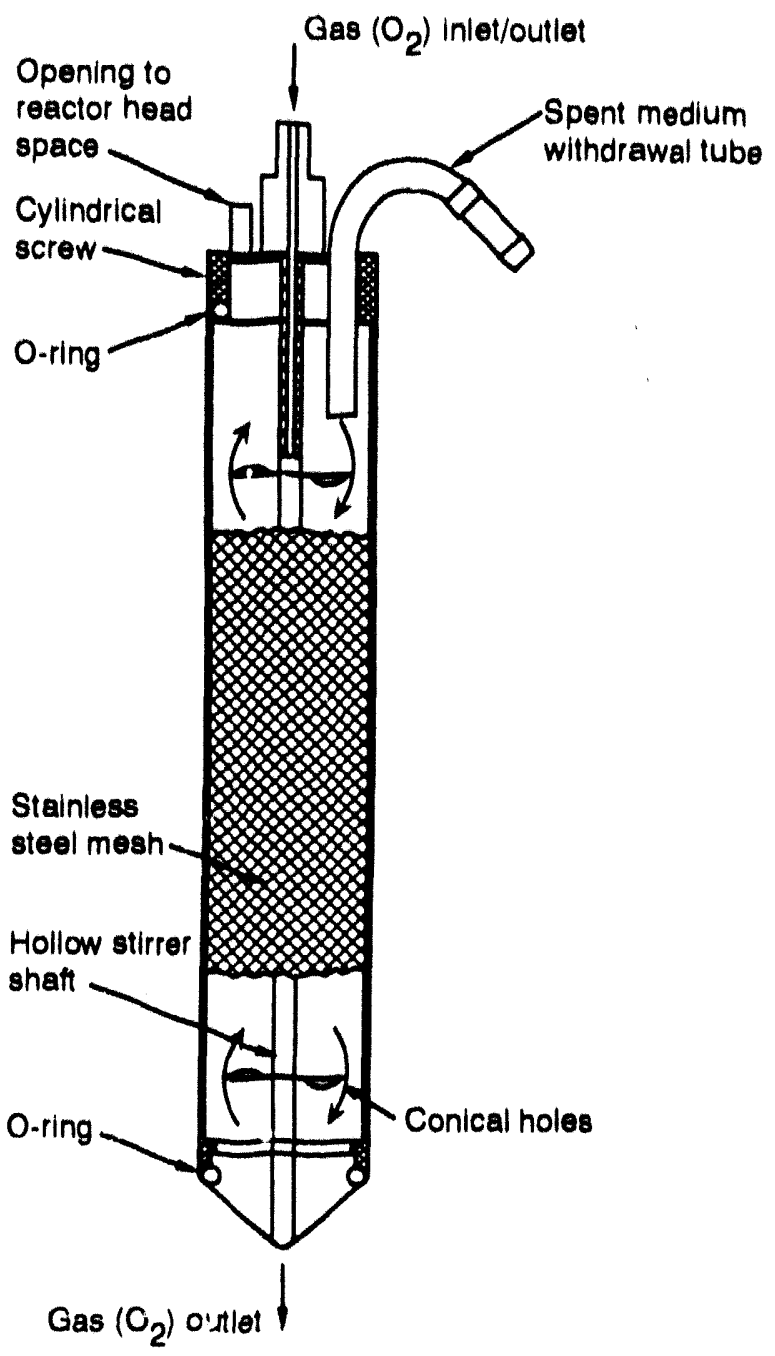

R930610

Figure 5. Vibro packuge.

plugging from the microcarriers and to keep the cage surface clean. Oxygen transfer capacity to cells inside the cage is directly influenced by cage vibration with optimum transfer occurring at an amplitude near $1.0 \mathrm{~mm}$.

Ahmed and Semmens ${ }^{8}$ used a microporous hollow fiber membrane with a sealed end to obtain bubbleless aeration of liquid media. Pure oxygen was maintained inside the sealed polypropylene fibers at a pressure below the bubble point allowing oxygen to flow across the hydrophobic membrane and dissolve upon contact with water held outside the membrane. Oxygen trunsfer effi. ciency was reported at $1(x) \%$ with an increase in enriched oxygen of up to $30 \%$. Because of the hydrophobic nature of the membrane, oxygen transfer through it is by gas-phase diffusion, which is approximately four orders of magnitude faster than liquid-phase diffusion. Consequently since the overall mass transfer coefficient $k$. is related to the individual transfer resistances, and gas and membrane resistances are negligihle, the following equation:

$\frac{1}{K}=\frac{1}{H k_{G}}+\frac{1}{H k_{m}}+\frac{1}{H k_{L}}$.

can te simplified to:

$\frac{1}{K}=\frac{1}{k_{L}}$.

where

$$
\begin{aligned}
H \quad= & \text { Henry's Law coefficient } \\
& \text { (atm-L/mg) }
\end{aligned}
$$

$\mathrm{k}_{\mathrm{G}}, \mathrm{k}_{\mathrm{M}}$, and $\mathrm{k}_{\mathrm{L}}=$ individual mass transfer coefficients $(\mathrm{cm} / \mathrm{s})$ of gas. membrane, and water respectively.

Hirasa et al. ${ }^{9}$ demonstrated increased oxygen transfer in water with a poly(dimenthysiloxune) hollow fiber membrane (silicone hollow fiber). The inner and outer diameters of the membrane were 0.5 and $1.0 \mathrm{~mm}$ respectively. The hollow fiber length was $1,000 \mathrm{~cm}$. Pressures applied to the membrane ranged from $0.98-3.92 \times 1()^{5} \mathrm{~Pa}$. The equation used for gas permeation inrough this homogeneous membrane was as follows:

$V=P_{e}\left(P_{1}-P_{2}\right) A / / L$

where

$$
\begin{aligned}
V \quad= & \begin{array}{l}
\text { gas volume permeated } \mid \mathrm{cm}^{3} \\
(\text { STP })]
\end{array} \\
P_{e} \quad= & \text { permeability coefficient } \mid \mathrm{cm}^{3} \\
& (S T P) \cdot \mathrm{cm} / \mathrm{cm}^{2} \cdot \mathrm{s} \cdot \mathrm{Pa}_{\mathrm{a}} \mid
\end{aligned}
$$




$$
\begin{aligned}
P_{1} \text { and } P_{2} & =\begin{array}{l}
\text { pressures at either side of the } \\
\text { membrane }(\mathrm{Pa}) \text { respectively }
\end{array} \\
A & =\begin{array}{l}
\text { permeation area of the mem- } \\
\text { brane }\left(\mathrm{cm}^{2}\right)
\end{array} \\
1 & =\text { permeation time }(\mathrm{s}) \\
L & =\begin{array}{l}
\text { thickness of the membrane } \\
(\mathrm{cm}) .
\end{array}
\end{aligned}
$$

The values of the overall oxygen transfer coefficient were proportional to 0.6 of the surface area of the hollow fiber. In comparison to various types of oxygen utilization systems, the hollow fiber system demonstrated an increase in oxygen enrichment of seven times. Figure 6 shows the relationship between hollow fiber length and oxygen transfer rates.

Gas mass transfer of air was increased by at least five times compared to flat membranes, using a membrane bioreactor featuring pulsating flow past a dimpled membrane. ${ }^{10}$ The bioreactor consisted of two hydrophobic polypropylene gas transfer membranes with feed flowing between them. The membranes had a large number of

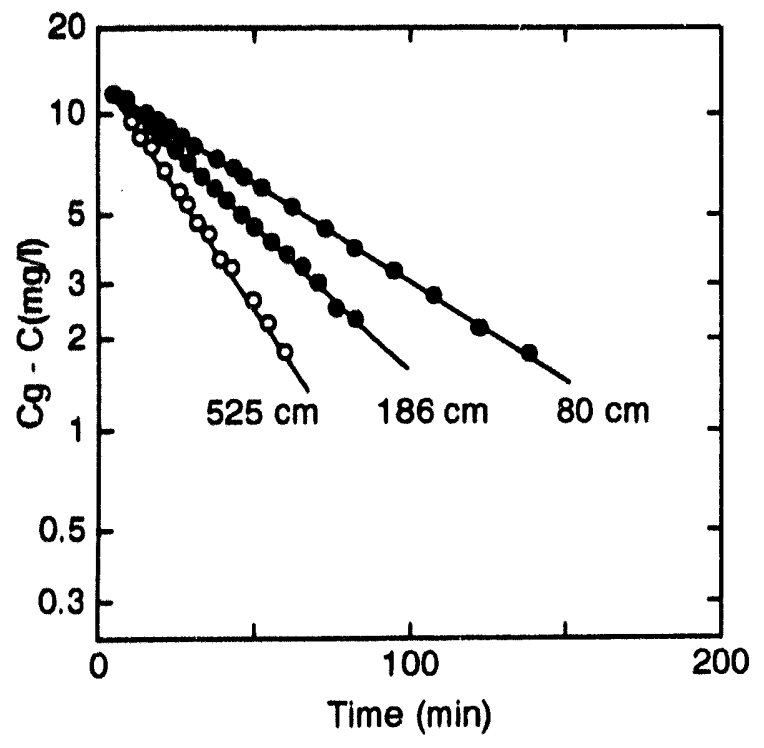

R93 0614

Figure 6. Effect of length of hollow fiber on oxygen transfer from silicone hollow fiber membrane to water. part-spherical dimples concave to the fluid channel. Pulsatile fluid flow was accomplished with two pistons moving sinusoidally against two pump bags in exact antiphase. The length (1) of the section of the channel (gas permeable) was $160 \mathrm{~mm}$ and width (b) was $65 \mathrm{~mm}$. The effective area of a single dimpled membrane was $11,791.8$ $\mathrm{mm}^{2}$. Bioreactor volume was $20 \mathrm{~mL}$, with the addition of end chambers, the end of the membranes and pump bags increased the volume to $120 \mathrm{~mL}$ (see Figure 7). Gas was supplied across the back of the membrane with a variable flow air pump. The pulsatile flow across the dimpled membranes caused vortex mixing (see Figure 8) and superior mass transfer compared to flat membranes. The vortex mixing also reduced membrane fouling.

Wu et al." demonstrated increased gas-liquid mass transfer with an airlift bioreactor containing a net draft tube of varying diameters. The system was essentially a bubble column with a diameter $13 \mathrm{~cm}$ and $200 \mathrm{~cm}$ high with a concentric draft tube $100 \mathrm{~cm}$ high of 24 mesh (see Figure 9). The diameter of the tube varied from 6.5, 8.0,9.0, and $10.4 \mathrm{~cm}$. Increased oxygen mass transfer was demonstrated with the draft tube diameters of 6.5 , 8.0 , and $9.0 \mathrm{~cm}$ as superficial air velocity increased (see Figure 10). Although gas mass transfer decreased with increased pressure, the dissolved oxygen concentration increased in the liquid with increased pressure.

Methane production rates from hydrogen and carbon dioxide were increased with hollow fibers, which allowed methanogens attached on the inside of the hollow fibers to have increased contact with liquid media and gases added from outside the hollow fibers. ${ }^{12}$ The cylindrical bioreactor was made of polycarbonate with an inside diameter of $22 \mathrm{~mm}$ and $273 \mathrm{~mm}$ long, containing 100 hollow fibers of hydrophobic polyethersulfone. The hollow fibers were $273 \mathrm{~mm}$ long, with outside diameters of $1.3 \mathrm{~mm}$ and inside diameters of $0.8 \mathrm{~mm}$, consisting of a $0.3-0.5 \mu \mathrm{m}$ pore size. A liquid mineral medium was supplied at a rate of $27 \mathrm{~mL} / \mathrm{h}$, with gas $\left(80 \% \mathrm{H}_{2}\right.$ and $20 \%$ $\mathrm{CO}_{2}$ ) flow through the bioreactor at races of $1,134,1,158$, and $2,722 \mathrm{~mL} / \mathrm{h}$. Methane 


\section{Schematic Cross-Section of Bioreactor}

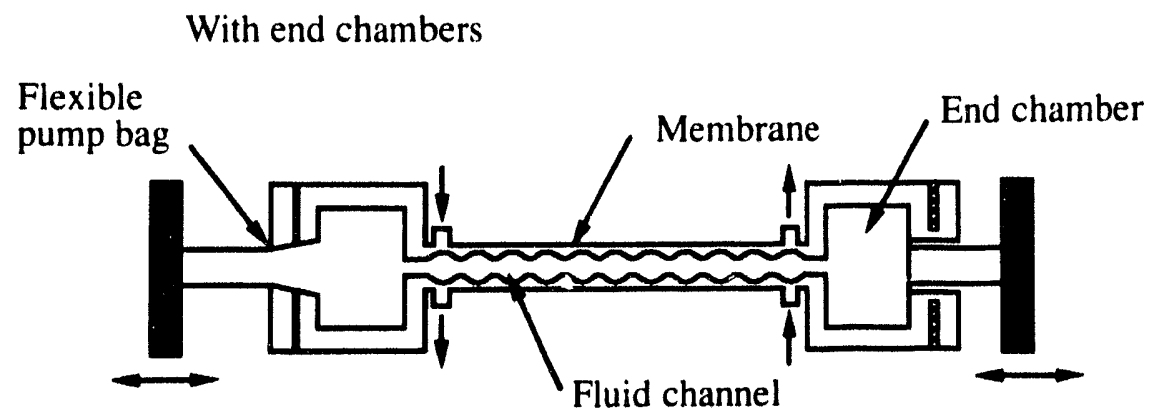

No end chambers

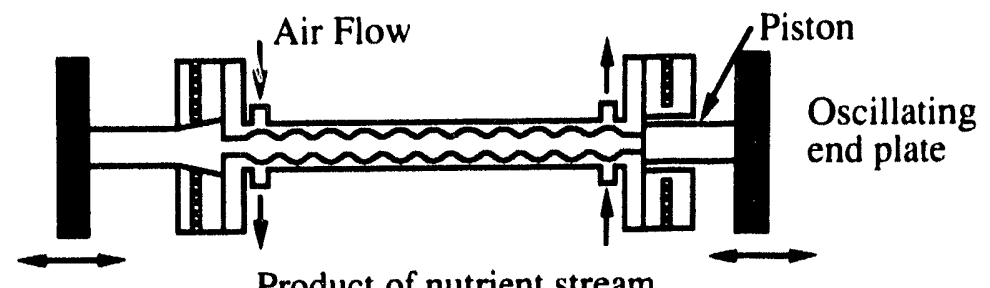

T93 1065

Figure 7. Cross-sectional view of the two bioreactor configurations.

\section{Vortex Formation}

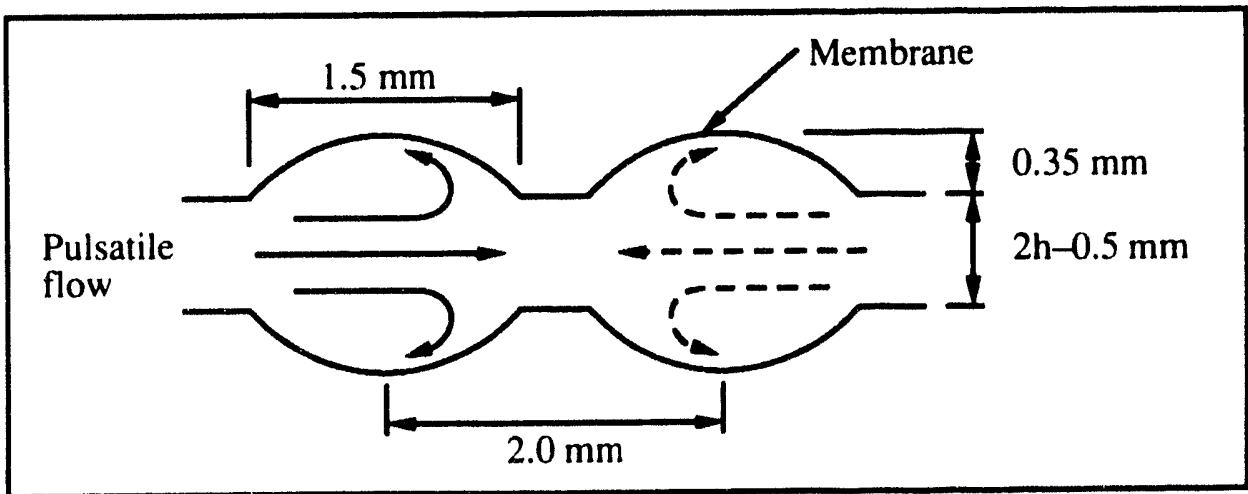

R930616

Figure 8. Cross-section showing the spherical geometry of the dimpled membrane. 


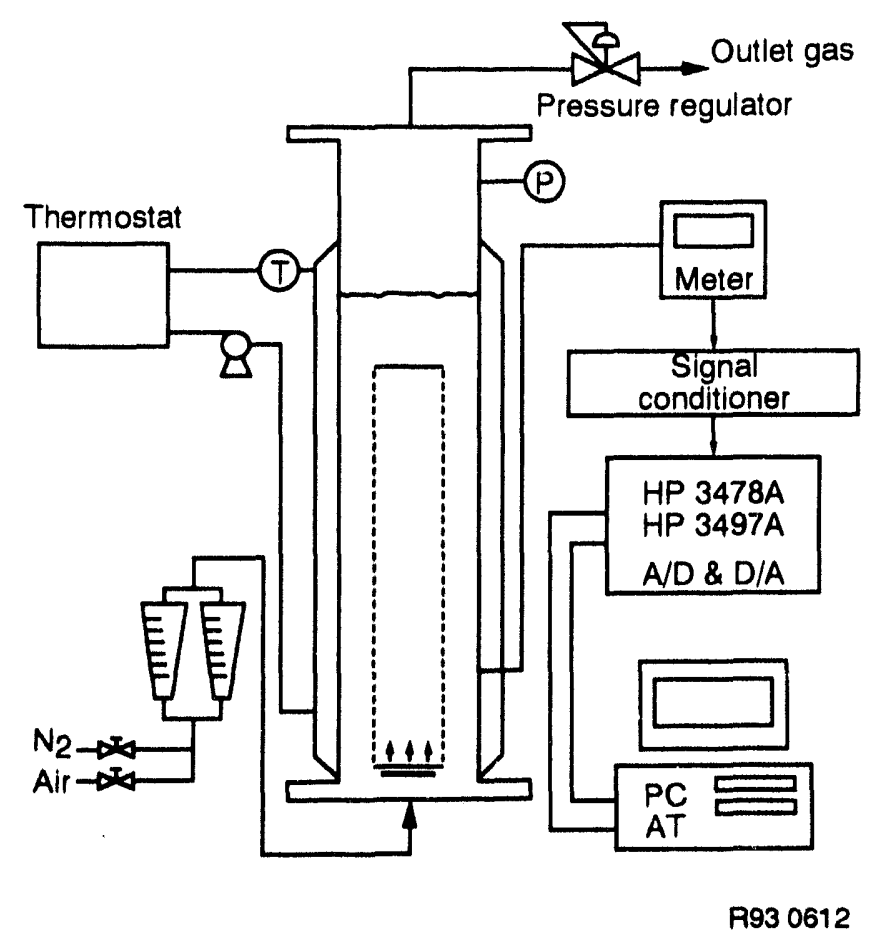

Figure 9. Schematic diagram of the experimental setup of airlift bioreactor with net draft tube.

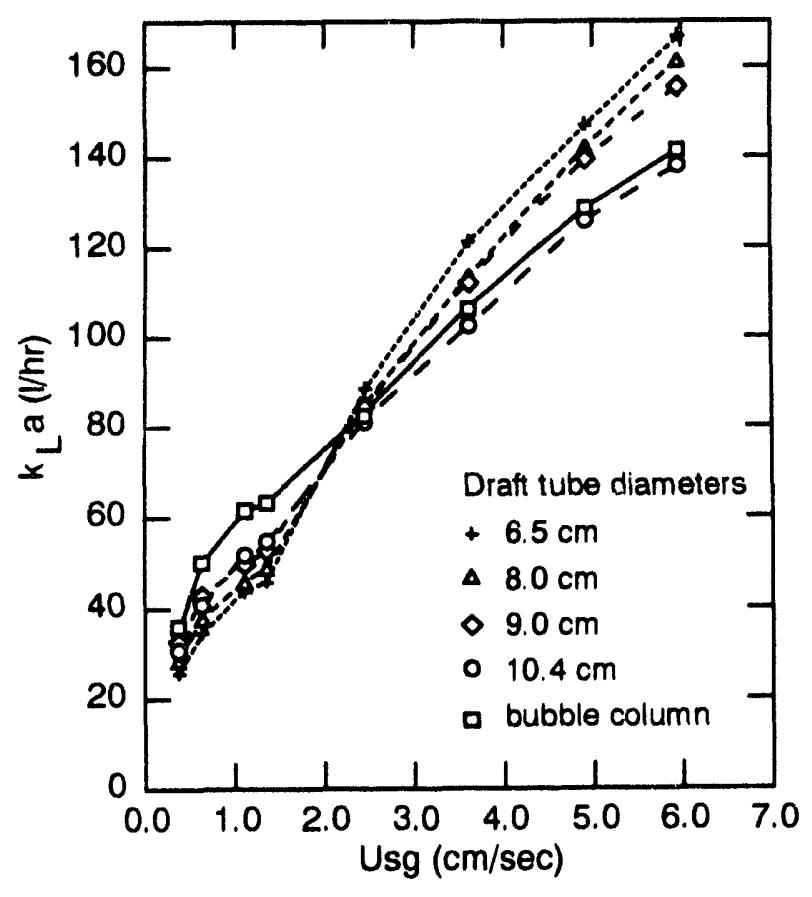

R93 0613

Figure 10. Volumetric mass transfer coefficient with respect to superficial air velocity for different draft tube diameters. 
production was proportional to hollow fiber length, with a $90 \%$ conversion rate.

Methanogen growth plugged the hollow fibers over time and was overcome by back-flushing of the cells out of the bioreactor with slight positive pressure, leaving the remaining cells to act as the inoculum for the next experiment.

Yano et al. ${ }^{13}$ modeled the reaction kinetics of methane production of the above work to design an optimized hollow fiber bioreactor. The following equation was used to solve for the relationship between bioreactor length (1), and the flow rate of $\mathrm{H}_{2}$, and $\mathrm{CH}_{4}$ through the bioreactor:

$$
\begin{aligned}
l= & F_{i n}\left(1-\varepsilon_{H}\right) \ln \left[1\left(1-Y_{h}\right)\right] \\
& +\varepsilon_{H} \gamma_{H} 0.65 \pi y^{2} k
\end{aligned}
$$

where

$$
\begin{aligned}
& F_{\text {in }}=\text { inlet gas velocity } \\
& \varepsilon_{H}=\begin{array}{l}
\text { hydrogen flow rate at the inlet } \\
\text { over } F_{\text {in }}
\end{array} \\
& Y_{H}=\text { conversion of } H_{2} \\
& y \quad=\quad \begin{array}{l}
\text { radius to the point of gas limita- } \\
\text { tion }
\end{array} \\
& k \quad=\text { reaction rate coefficient. }
\end{aligned}
$$

Apel et al. ${ }^{14}$ demonstrated a $90.4 \%$ conversion rate of methane using methanotrophs in a gasphase bioreactor. The methanotrophs were altached to biorings that acted as support for the bacteria while nutrients were added by pumping them to the top of the bioreactor and allowed to trickle down the supports. The microorganisms were in direct contact with the gaseous substrate and therefore minimized diffusional resistance. Additional work by Apel et al. ${ }^{15}$ demonstrated increased methane oxidation using $4 \%$ kaolin mixed with a mineral salts medium in gas-phase bioreactors. These bioreactors operate similarly to trickle bed bioreactors and therefore the ratio of partial pressures of gaseous reactants entering and leaving the bioreactor can probably be written as:

$\ln \frac{P_{S}{ }^{\prime}}{P_{S}{ }^{i}}=\frac{K_{L} a}{H} \frac{\varepsilon_{L} h R T S}{G}$

where

$$
\begin{aligned}
& \varepsilon_{\mathrm{L}} \quad=\text { fraction of liquid in the column } \\
& \mathrm{h}=\text { height of the column } \\
& \mathrm{S}=\begin{array}{l}
\text { cross sectional area of the } \\
\text { column }
\end{array} \\
& \mathrm{R}=\text { ideal gas constant } \\
& \mathrm{T}=\text { absolute temperature } \\
& \mathrm{G}=\text { gas flow rate. }
\end{aligned}
$$

Applegate and Stephanopoulos ${ }^{16}$ used a single-pass, plug-flow bioreactor to supply oxygen to entrapped hybridoma cells via silicone tubes threaded through the square channels of a ceramic monolith. Mean pore size ranged from 20-22 $\mu \mathrm{m}$ with a normal size distribution from $2-\sim 150 \mu \mathrm{m}$, giving a $50 \%$ porosity to the bioreactor. This allowed for a cell concentration in the bioreactor of $>10^{8}$ cells $/ \mathrm{cm}^{3}$.

The use of a separate oxygenation system created an independent oxygen supply, thereby eliminating the need for rapid recirculation encountered in recycle bioreactors. Since oxygen limiting conditions require rapid recycling, recycling bioreactors are reported to have a very low single-pass substrate conversion rate and can be modeled as a well mixed bioreactor. The bioreactor described here is a single-pass, plug-flow bioreactor (see Figure 11) that can minimize the accumulation of inhibitory metabolic by-products and thereby increase the rate of substrate conversion and produce higher product yields ( see Figure 12). This bioreactor permits protection of cells from hydrodynamic effects and has a minimum of moving parts and simplicity of operation when compared to a recycle bioreactor consisting of the same ceramic material. 


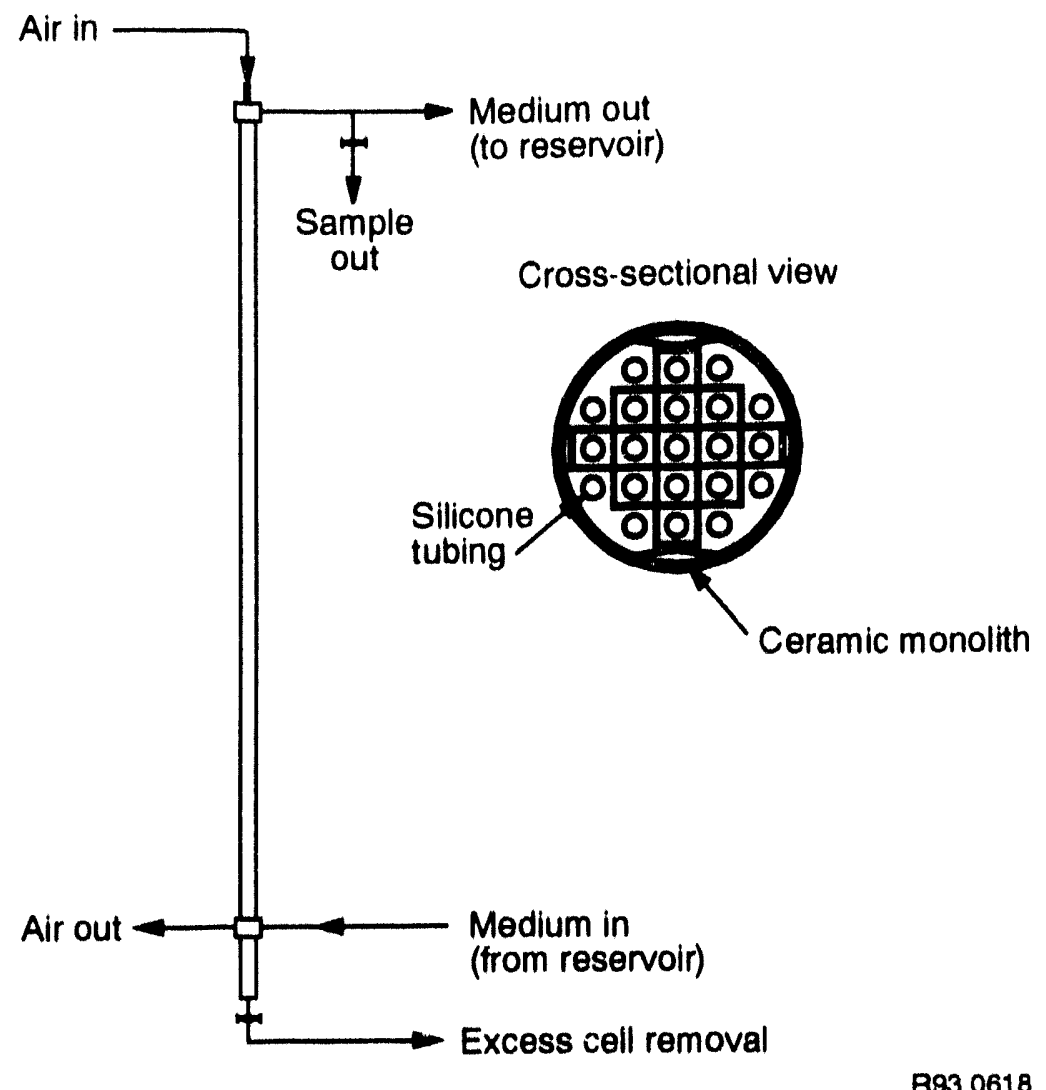

Figure 11. Schematic diagram of single-pass bioreactor.

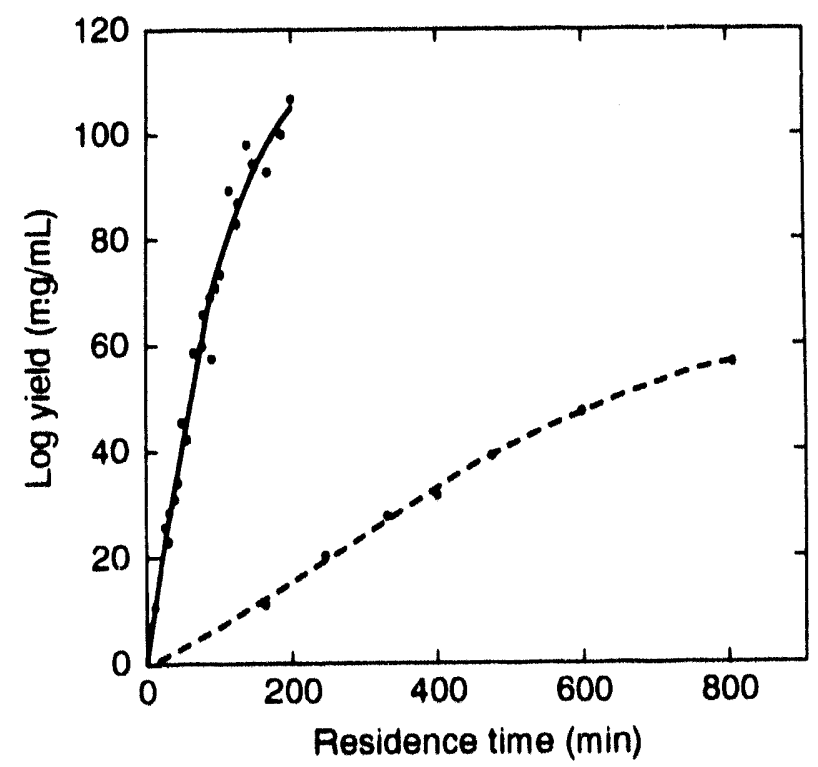

Single-pass bioreactor

...... Recycle bioreactor

L93 0595

Figure 12. Comparison of antibody yield between the single pass bioreactor and the recycle bioteactor. 
Considerations for scale-up of a single-pass, ceramic matrix bioreactor include effective oxygen diffusivities in liquid and through cell mass, specific oxygen consumption rates, and gas and liquid flow rates. A significant advantage of this bioreactor design involves the high oxygen concentration in the gas phase with minimum oxygen depletion occurring because of axial diffusion. From the cross-sectional diagram of one channel (Figure 13), liquid flows in the z-direction while oxygen diffuses from the gas phase through the tubing wall, across the open channel, and into the porous wall where it is consumed by entrapped cells.

Oxygen mass transport in this system is governed by the following equations:

$$
\begin{aligned}
& \underline{\underline{L}}(\nabla c)=D \nabla^{2} C \\
& D{ }^{\prime} \cdot \nabla^{2} c_{n}=S_{v}
\end{aligned}
$$

where

$$
\begin{aligned}
& \underline{v} \quad=\begin{array}{l}
\text { velocity field of liquid flow- } \\
\text { ing through the open channel }
\end{array} \\
& \mathrm{c}=\begin{array}{l}
\text { oxygen concentration in the } \\
\text { channel }
\end{array}
\end{aligned}
$$
$c_{u} \quad=$ oxygen concentration in the porous wall-cell mass composite

$D$ and $D_{w}=$ effective oxygen diffusivities through liquid and the porous wall-cell mass composite

$S_{v} \quad=a$ uniform volumetric oxygen consumption rate ( 0 order kinetics).

Equation 13 refers to the open channel between the silicone tubing and the porous wall, while Equation 14 describes oxygen diffusion and consumption by cells immobilized in the porous wall.

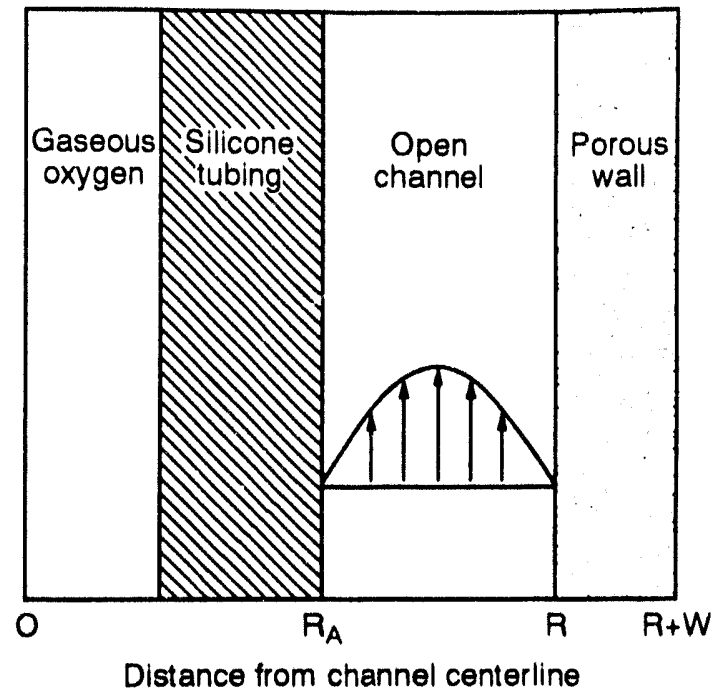

L93 0602

Figure 13. Cross-sectional view of singlepass bioreactor as formulated in the oxygen transport model.

Equations 13 and 14 are coupled through boundary conditions at the channel-porous wall interface, while other boundary conditions are imposed at the tubing wall-channel interface and the inlet io the bioreactor. These boundary conditions are as follows, assuming fully developed flow at the entrance and a flat profile for the gasphase concentration of oxygen in the tubing:

$c=c_{T}$ at $y=R_{A}$

$c=c$ at $y=R$

$-D\left(\frac{d c}{d y}\right)=-D_{H}\left(\frac{d c \underline{u}}{d y}\right)$ at $y=R$

$\frac{d c_{n}}{d y}=0$ at $y=R+W$

$c=c_{L}$ at $z=0$

where

$$
\begin{aligned}
& z \quad=\begin{array}{l}
\text { axial position along the } \\
\text { bioreactor }
\end{array} \\
& y=\begin{array}{l}
\text { transverse position across the } \\
\text { channel and porous wall }
\end{array}
\end{aligned}
$$




$$
\begin{aligned}
& R_{A}=\quad \begin{array}{l}
\text { distance between the channel } \\
\text { centerline and outer tubing wall }
\end{array} \\
& R_{=} \quad \begin{array}{l}
\text { half-channel width and corre- } \\
\text { sponds to the interface between } \\
\text { the medium and the porous wall }
\end{array} \\
& W=\text { half-wall thickness } \\
& c_{T}=\begin{array}{l}
\text { liquid-phase oxygen concentra- } \\
\text { tion at the tubing wall-fluid } \\
\text { interface }
\end{array} \\
& c_{\mathrm{L}}=\begin{array}{l}
\text { inlet liquid-phase oxygen con- } \\
\text { centration. }
\end{array}
\end{aligned}
$$$$
\mathrm{W}=\text { half-wall thickness }
$$$$
\mathrm{c}_{\mathrm{T}}=\text { liquid-phase oxygen concentra- }
$$$$
\text { tion at the tubing wall-fluid }
$$$$
\text { interface }
$$

In order to optimize bioreactor scale-up, equations were developed relating to design variables such as bioreactor length and wall thickness to operating variables such as gas flow rate and oxygen consumption rate. The design criteria developed were based on maintaining a minimum oxygen concentration throughout the bioreactor. The minimum oxygen concentration occurs at the midsection of the porous wall, and its value depends on the dissolved oxygen concentration at the tubing wall-liquid interface, $c_{T}$, as follows:

$$
\begin{aligned}
C_{u, \text { mit }}= & C_{T_{\text {m,n }}}+\left(\frac{S, R^{2}}{4 D_{n}}\right)\left\{\left(1+\frac{W}{R}\right)^{2}\right. \\
& \left.\times\left[1-2 \ln \left(1 \frac{W}{R}\right)\right]\right\} \\
& -S, \frac{W}{2 D}\left[2\left(\frac{R}{W}\right)+1\right] \ln \left(\frac{R_{A}}{R}\right)
\end{aligned}
$$

where

$$
\begin{aligned}
c_{k, \text { min }}= & \begin{array}{l}
\text { dissolved oxygen concentration } \\
\text { at the wall midsection. }
\end{array}
\end{aligned}
$$

The rate of oxygen supplied to the culture in this bioreactor design will limit bioreactor scale-up. The following equation determines the minimum gas flow rate required by formulating a mass balance on the tube side oxygen supply, based on an acceptable $c_{t, m i n}$ :

$$
F_{\min }=\frac{S_{1 L} \pi\left|(R+W)^{2}-R^{2}\right|}{C_{R}-H C_{1, \min }}
$$

where

$$
\begin{aligned}
c_{G}= & \text { inlet gas phase } \mathrm{O}_{2} \text { compositions } \\
\mathrm{c}_{\mathrm{W}}= & \begin{array}{l}
\text { dissolved oxygen concentration } \\
\text { at the wall midsection. }
\end{array} \\
\mathrm{F}= & \text { gas flow rate through each tube } \\
\mathrm{H}= & \begin{array}{l}
\text { Henry's Law coefficient for } \mathrm{O}_{2} \\
\text { in medium. Oxygen permeability } \\
\text { through silicone was not consid- } \\
\text { ered in the above equation, how- } \\
\text { ever. }
\end{array}
\end{aligned}
$$

Another method to increase the oxygen supply to cells is to increase gas flow rates through the tubing so that the transverse oxygen profile at the bioreactor exit is maintained above a minimum value throughout the porous wall. Maximum flow rate is determined by the maximum pressure drop the tubing can sustain. Therefore maximum bioreactor length can be determined in the following way:

$L_{\text {max }}=\left\{\frac{\left.\Delta P\right|_{\text {max }} D_{i}^{4}}{128 \mu S_{1}}\left[\frac{C_{i}-C_{r_{\text {min }}}}{(R+W)^{2}-R^{2}}\right]\right\}^{1 / 2}$

where

$$
\begin{aligned}
|\Delta \mathrm{p}|_{\max } & =\begin{array}{l}
\text { maximum pressure drop the } \\
\text { tubing can sustain }
\end{array} \\
\mu & =\text { gas viscosity } \\
\mathrm{D}_{\mathrm{i}} & =\text { inner tubing diameter. }
\end{aligned}
$$

Since gases are more soluble in water at increased pressure, bioreactors designed to operate at increased pressures have been successful in increasing bacterial growth rates. Numerous bioreactor designs have been developed for this purpose and can operate at pressures up 10 $7(0)$ atmospheres. Nelson et al. ${ }^{17}$ demonstrated that bacterial growth rates can vary at increased pressure based on whether hyperbaric or hydrostatic pressures are used (see Figure 14). Hydrostatic pressurization offers the advantages of easy pressure control and safety, but the effectiveness of these systems is limited when gaseous 


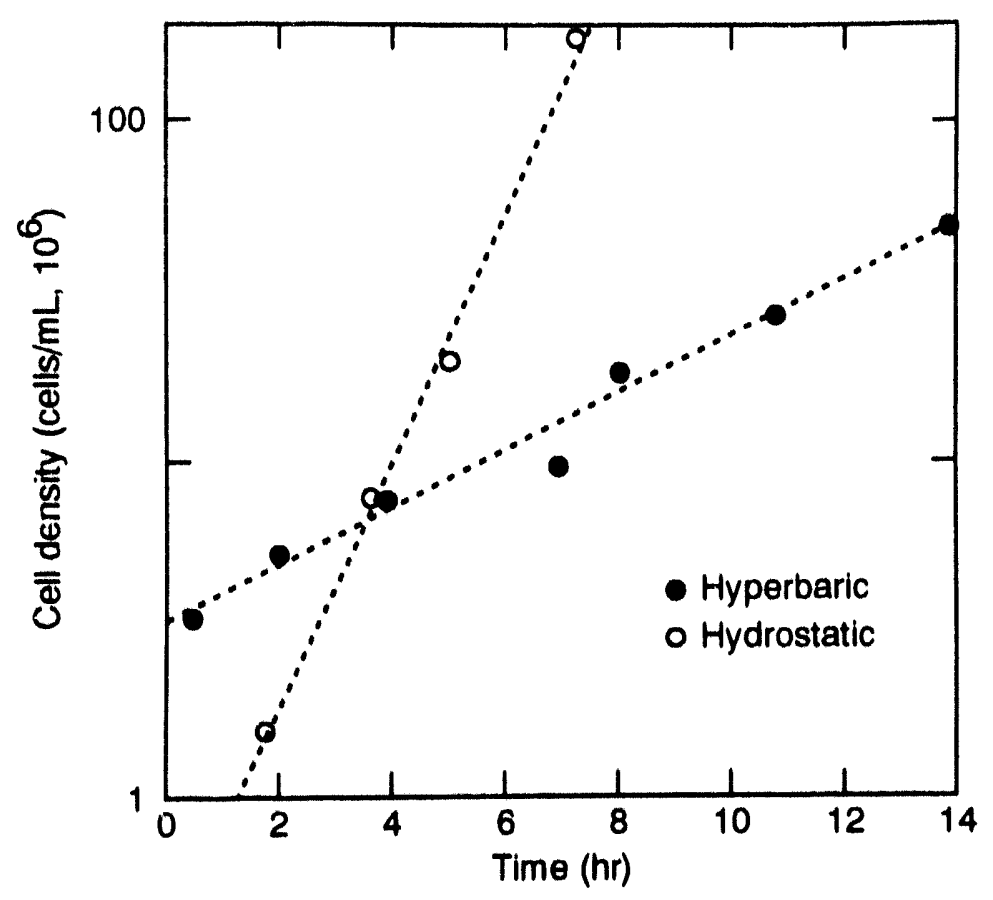

R93 0621

Figure 14. Growth of ES4 at $95^{\circ} \mathrm{C}$ and 500 atm in the hydrostatic vessel and the glass-lined hyperbaric vessel.

substrates are involved. A bioreactor used to compare effects of hyperbaric and hydrostatic pressures on bacterial growth is shown in Figure 15.17 A modified high-pressure bioreactor system was modified to allow hyperbaric studies to be conducted in parallel with hydrostatic experiments.

Enhanced oxygen transfer rates have been accomplished with chemical additives acting as oxygen vectors. In these chemicals, oxygen has a high solubility, and when combined with water allows the medium to carry more oxygen. Chemicals commonly used in biotechnology include hydrocarbons, hemoglobin, and perfluorocarbons. Hydrocarbons are inexpensive and can be separated by decantation or centrifugation.
Torrijos ${ }^{18}$ demonstrated increased growth kinetics with $n$-alkanes. Disadvantages of $\mathrm{n}$-alkane use include damage to cell membranes and potential microbial oxidation.

Adlercreutz and Mattiason ${ }^{19}$ used hemoglobin as an oxygen carrier for Gluconobacter oxyddans with increased growth and productivity. Although hemoglobin provec sucressful, the upper limit of use was demonstrated at $85 \mathrm{mg} / \mathrm{mL}$. Recycling of hemoglobin must be accomplished with ultrafiltration, requiring the need for immobilized cells to be used with soluble hemoglobin. Hemoglobin was oxidized to methemoglobin, thereby decreasing its oxygen carrying capacity. Khosla and Bailey ${ }^{2()}$ overcame some of the problems in working with hemoglobin by cloning the hemoglobin gene into Escherichia coli, producing increased growth rates and oxygen utilization. 


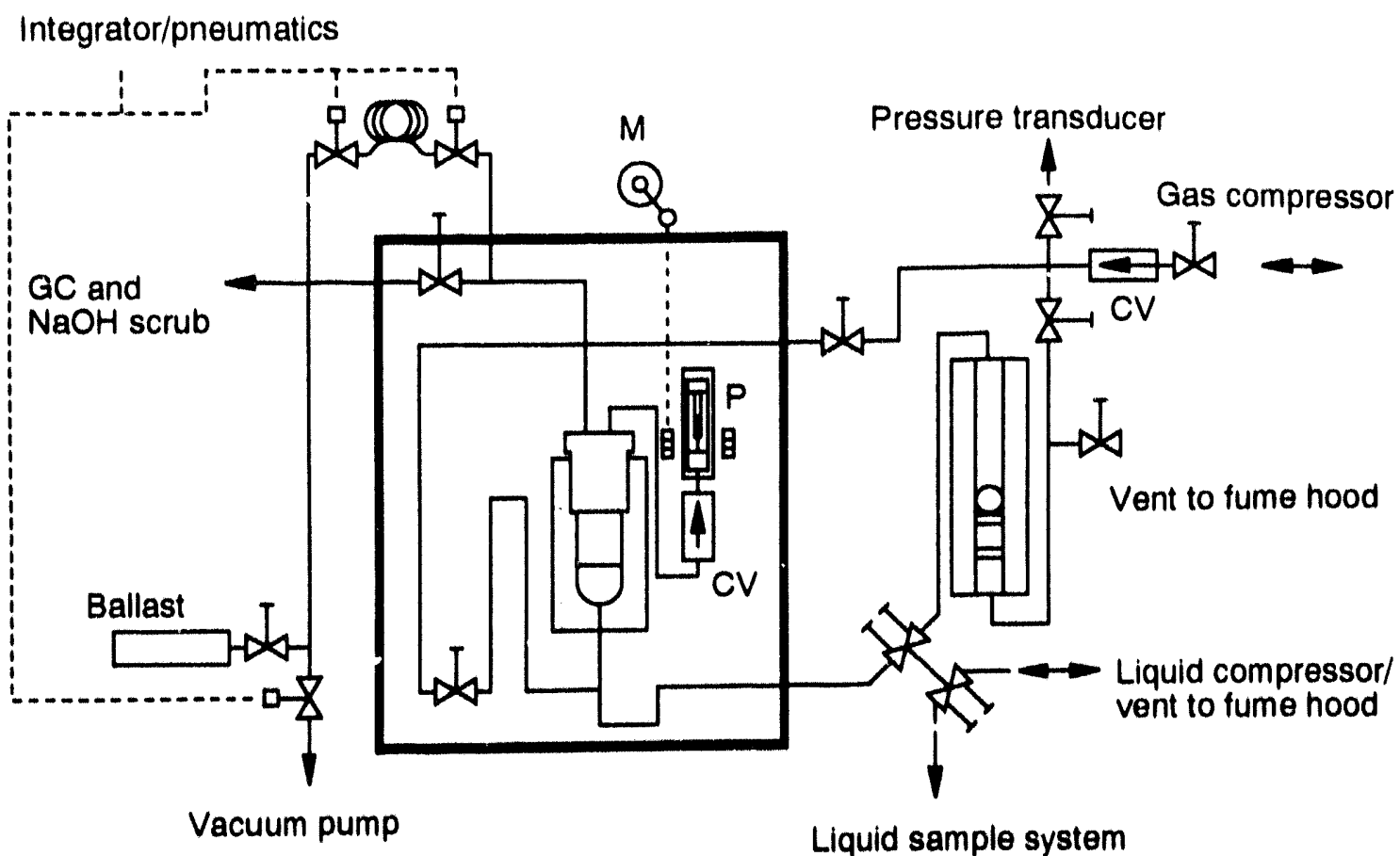

L93 0602

$$
\begin{aligned}
& \text { CV - Check valves } \\
& P \text { - Gas recirculation pump } \\
& M \text { - Motor driven crank } \\
& \text { GC - Gas chromatograph }
\end{aligned}
$$

Figure 15. Schematic diagram of modified high-pressure system.

Perfluorocarbons are hydrocarbons with the hydrogens replaced with fluorine molecules. Their gas dissolving capacity is related to the ease in which solute molecules can fit in between the fluorine molecules ${ }^{21}$ rather than a specific chemical reaction. Much of the research pertaining to perfluorocarbons as oxygen carriers has been reviewed by Rols 21 and King et al. 22 Perfluorocarbons have been demonstrated as suitable blood substitutes and have improved the productivity of aerobic microorganisms. Because of their high cost $(-35()-\$ 4(0)$ per gallon), they would need to be recycled in any bioprocess in which they are used. Dammiano and Wang ${ }^{23}$ recycled perfluorocarbons in a spray column bioreactor by remov- ing the perfluorocarbons from the bottom of a cylindrical bioreactor where they sellled and pumping them back through the system by means of aspiration after they were reoxygenated outside the bioreactor (see Figure 16). Because of the high volatility of many of the perfluorocarhons, a means of trapping them needs to be in place such as that used by Damianno and Wang, 23 where a refrigerated trap was used to condense any escaping perfluorocarbons from the system (see Figure 16). Perfluorocarbon emulsions have also been used with beller results than the liquids, because of their ability to remain in suspension and have more contact lime with the microorganisms in the media. 


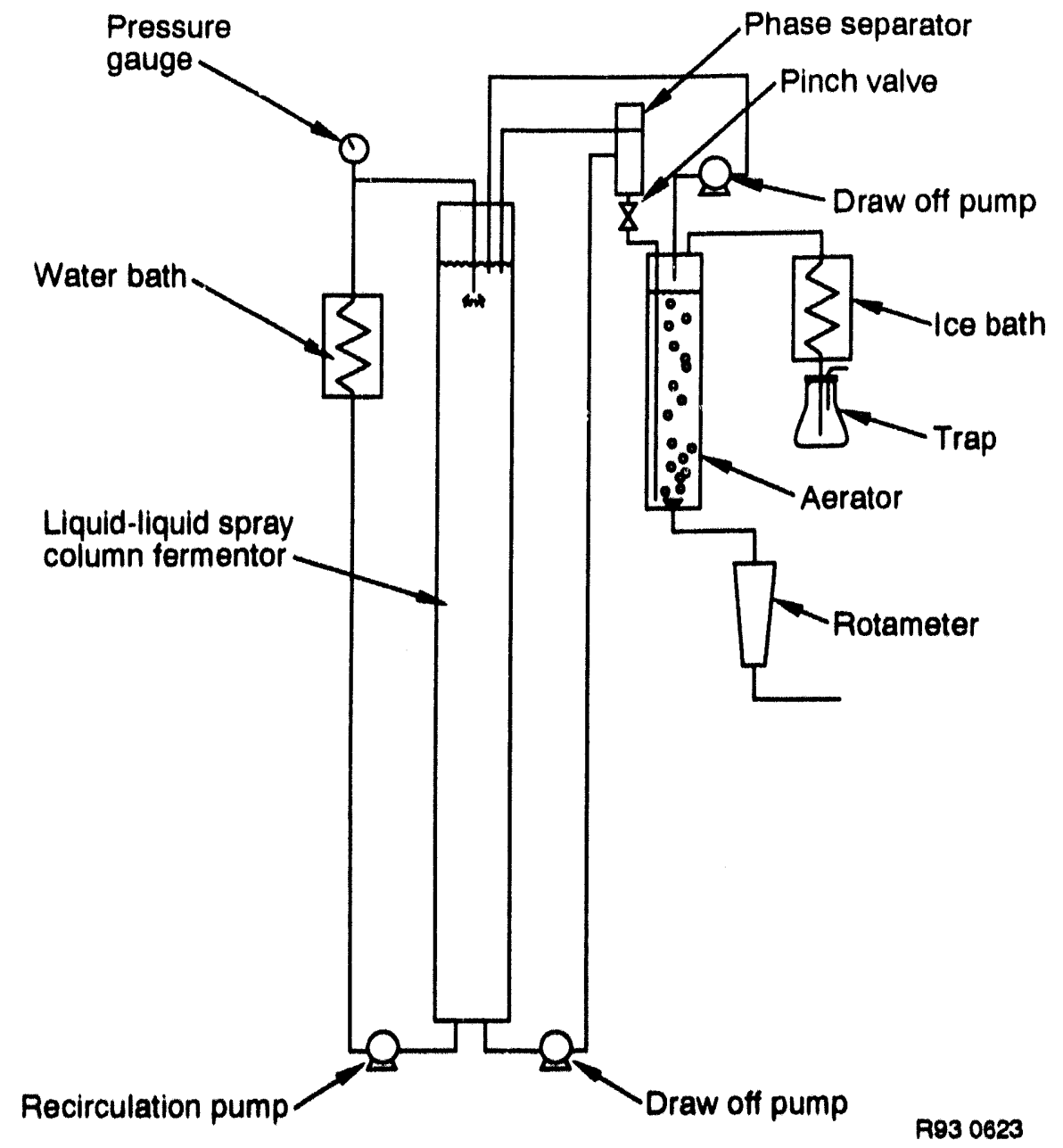

Figure 16. Schematic of liquid-liquid spray column fermentor system.

Ju et al. ${ }^{24}$ have investigated the use of perfluorocarbon emulsions and developed a model to describe their potential oxygen enhancement effects in liquid media. The model is as follows:

$E=\left[\left(\frac{P_{l^{\prime}}}{P_{0}}\right)\left(\frac{k_{0}}{k_{0}}\right)\right]^{1 / 2}$

where

$$
\mathrm{E}=\begin{aligned}
& \text { oxygen transfer enhance- } \\
& \text { ment factor }
\end{aligned}
$$

$P_{\mathrm{e}}$ and $P_{0}=$ oxygen permeability $[(\mathrm{mol}$. $\left.\mathrm{cm}^{2} /(\mathrm{L} \cdot \mathrm{s} \cdot \mathrm{atm})\right)$ of the effective value in a homogeneous system and the original value, respectively

$$
\begin{aligned}
k_{e} \text { and } k_{0}= & \text { effective and original values } \\
& \text { of oxygen solubility in terms } \\
& \text { of Henry's law constant } \\
& {[(\text { mol/(L.atm })] . }
\end{aligned}
$$

Gases other than oxygen are also soluble in perfluorocarbons. King et al. ${ }^{22}$ suggested a possible use of perfluorocarbons in microbial culture as carriers of other metabolically important gases. Perfluorocarbons enhanced the growth of Clostridium perfiringens when grown with carbon dioxide. ${ }^{25} \mathrm{Ju}$ and Armiger $^{24}$ used perfluorocarbons to remove carbon dioxide from aerobic microbial cultures. 
Perfluorocarbons also have several other characteristics that may make them potentially more valuable in bioprocessing, including (a) nonbiodegradability, (b) enhanced solubility of numer- ous hydrocarbons, (c) high electrical conductivity, and (d) low surface tension. Some of these characteristics are detailed in Tables 1 and 2.

Table 1. Typical properties of fluorocarbons.

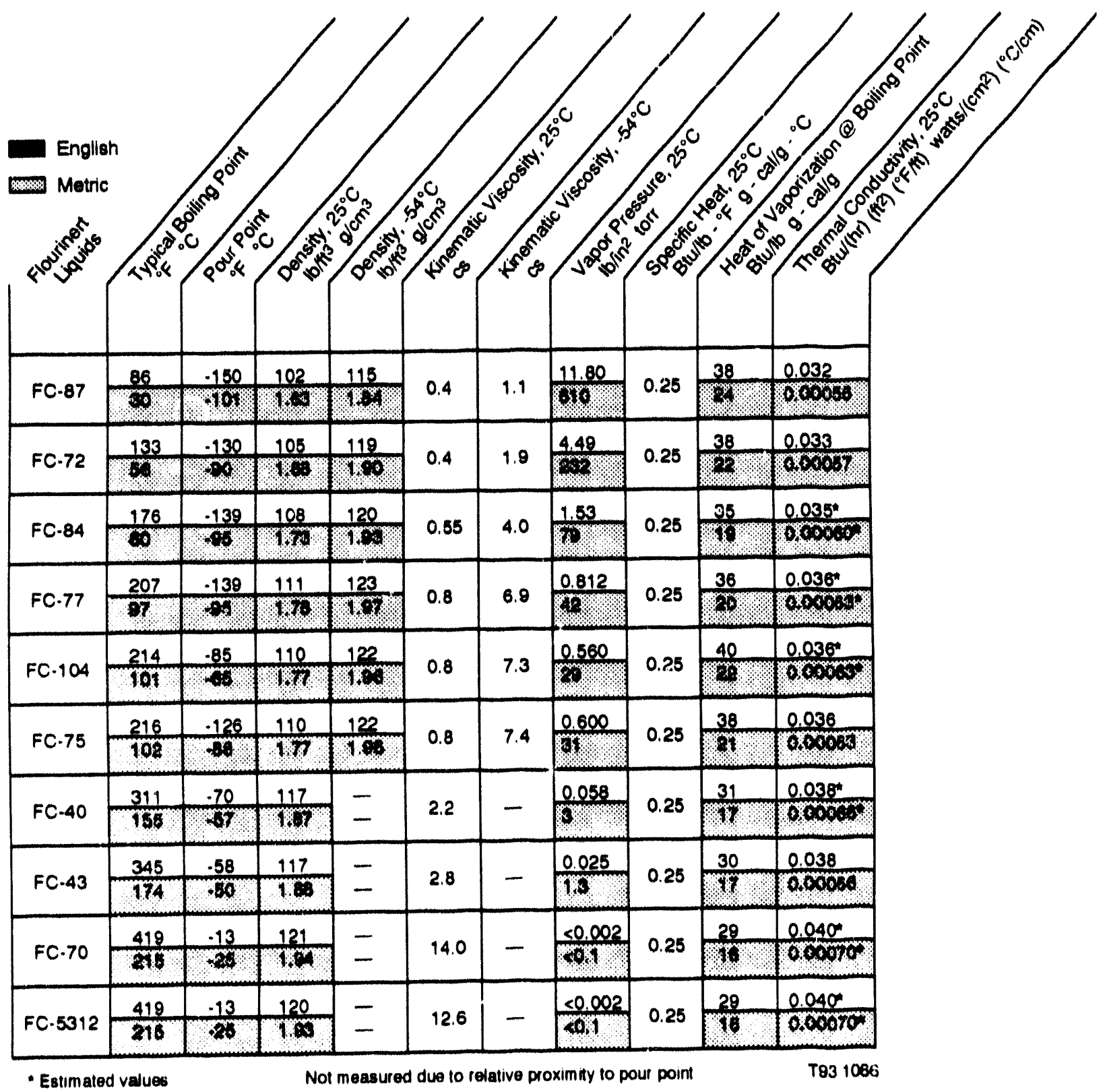


Table 1. (continued).

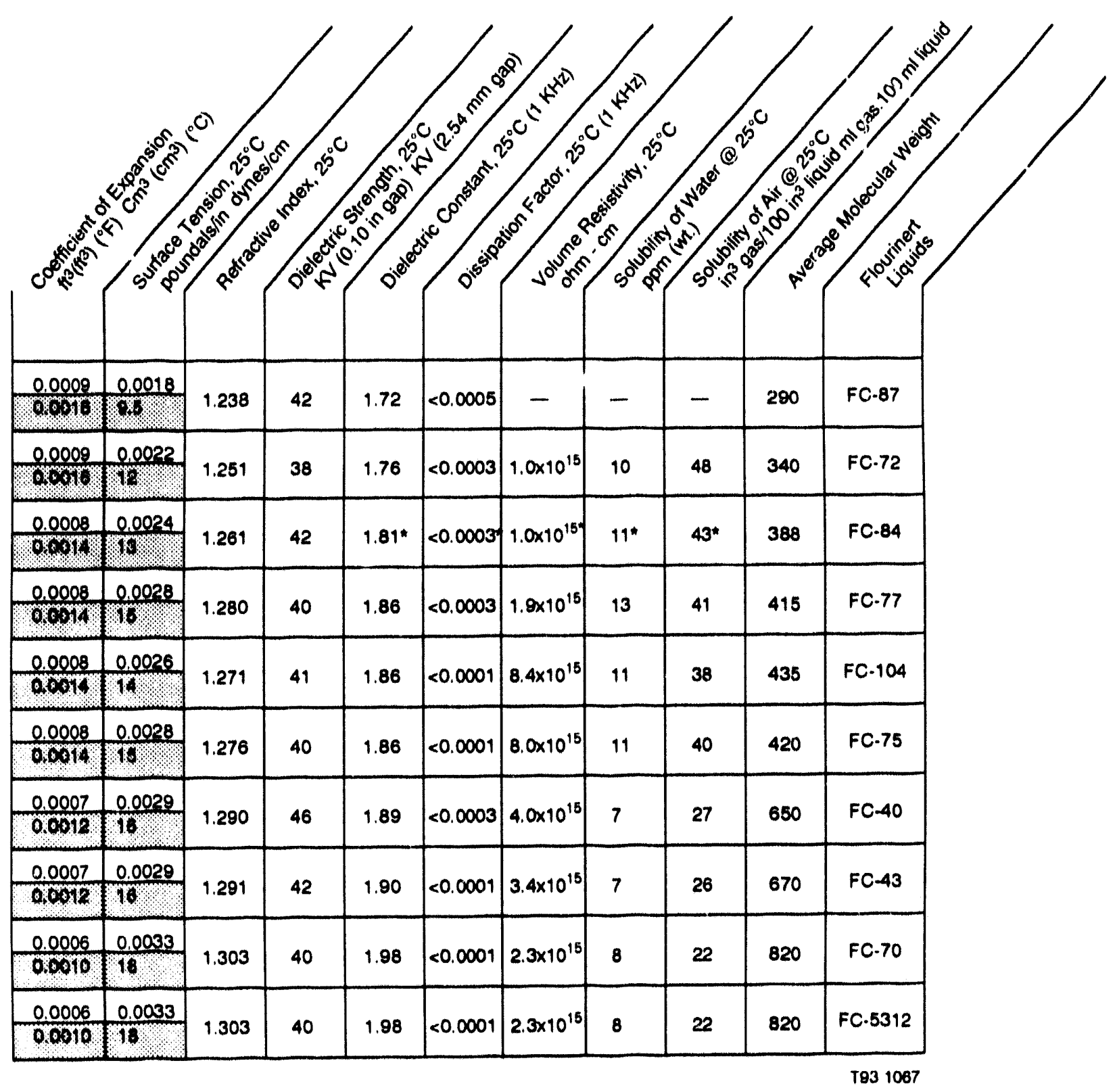


Table 2. Some properties of the unwoven fibrous packing materials.

Elemental analysis

\begin{tabular}{|c|c|c|c|c|c|c|c|c|c|}
\hline Fubrics & Composition & $C^{\prime}$ & $H$ & $\mathrm{~N}$ & $s$ & Ash & $\mathrm{pH}$ & $\begin{array}{l}\text { Moisture } \\
\text { content. } \\
\%\end{array}$ & $\begin{array}{l}\text { Specific } \\
\text { surface area. } \\
\mathrm{m}^{2} \cdot \mathrm{g} .1\end{array}$ \\
\hline Ruyon & Rayon & 42.5 & 0.5 & 0 & 0 & 0 & $0.1^{11}$ & 8.78 & $242^{d}$ \\
\hline Polyester & Polyester & 62.2 & 4.5 & 0 & 0 & 0.6 & $5.4^{h}$ & 0.91 & 3.34 \\
\hline Acryl & Acrylic & 67.9 & 5.9 & 26.9 & 0 & 0 & $5.2^{h}$ & 0.9 .5 & $<3^{4}$ \\
\hline Asgard & $\begin{array}{l}\text { Activated carbon } \\
\text { fabric made from } \\
\text { rayon }\end{array}$ & 56.8 & 3.7 & 4.4 & 0.4 & 7.3 & $2.61^{b}$ & 8.52 & $5\left(14^{d}\right.$ \\
\hline FN-20OCF-15 & $\begin{array}{l}\text { Carbon fiber } \\
(20 \%)+\text { fibrous } \\
\text { charcoal }(80 \%)^{4}\end{array}$ & 91.4 & 0.5 & 0.6 & 0 & 0.4 & 5.5 .36 & 4.98 & $1,2(x)^{e}$ \\
\hline FN-1.50PE-1.5 & $\begin{array}{l}\text { Polyester } \\
(30 \%)+\text { fibrous } \\
\text { charcoal }(70 \%)\end{array}$ & 86.0 & 3.9 & 0.3 & 0 & 0 & $5.36^{\prime}$ & 3.18 & 1.0 .5()$^{e}$ \\
\hline FN-3(X)PS-15 & $\begin{array}{l}\text { Fibrous charcoal } \\
(1(x) \%)\end{array}$ & 89.2 & 0.8 & 0.4 & 0.1 & 0.2 & $5.28^{c}$ & 1.95 & $1.5(x)^{e}$ \\
\hline FN-30()PP-15 & $\begin{array}{l}\text { Polypropylene } \\
(10 \%)+\text { fibrous } \\
\text { charcoal }(90 \%)\end{array}$ & 70.4 & 1.2 & 0.2 & () & 0 & $4.84^{\circ}$ & 17.7 & $1,350^{e}$ \\
\hline FN.2(X)AC & Polyacrylonitrite & 6.9 .7 & 2.0 & $4.1)$ & 0.3 & 1.6 & $5.499^{\circ}$ & 21.8 & $562^{d}$ \\
\hline \multicolumn{10}{|c|}{ a. Surface area of the fibrous charcoul is $1,5(x) \mathrm{m}^{2} \cdot \mathrm{g}^{-1}$. } \\
\hline \multicolumn{10}{|c|}{ b. $\quad 1: 19$ (fab.: water) ratio (see tex1). } \\
\hline \multicolumn{10}{|c|}{ c. $1: 34$ (fab.: water) ratio (see text). } \\
\hline \multicolumn{10}{|c|}{ d. The values were measured by the determination of pore volume distribution by methyl alcohol isotherm method (7). } \\
\hline c. The values & c calculated from I & rous cl & al cor & It of th & orics. & & & & \\
\hline
\end{tabular}




\section{VOC REMOVAL}

Several bioreactor designs have been reported for removing VOCs from gas streams. A successful bioreactor design needs to solve the problems of oxygen usually being required for the rapid metabolism of VOCs and the immiscible nature of VOCs with water. These problems are usually addressed by increasing the surface area inside the bioreactor with a solid support medium. Support media selection depends on good pneumatic conductivity to minimize pressure drop and gas movement power requirements, as well as high surface area and good wetting sorptive characteristics. These media allow for increased surface area for bacterial growth, oxygen transfer, and increased sorption for hydrophobic VOCs such as gasoline and diesel fuel.

Bioreactors similar in design to those of Apel ${ }^{14.15}$ mentioned earlier, (see Figure 17) were used by Douglass et al., ${ }^{26}$ (see Figure 18). Various packings were identified as better solid media and included; soil, peat, and fiberglass wool. Other packing media used in the biological removal of VOCs were composts, sand, bark peal, heather, volcanic ash, or mixtures of these. ${ }^{27}$ Tiwaree ef al. ${ }^{28}$ used different fabrics (see Tuble 2) as carriers of microorganisms in the biological deodorization of dimethyl sulfide. Employing the bioreactor design outlined in Figure 19 they found the activated carbon fabric FN-2(X)CF-15 had the highest rate of substrate removal (see Table 3) following an acclimation period in the bioreactor. The results of bacterial counts from the fabrics, using three different media (see Tuble 4), demonstrated that fabric FN-200CF.15 also had the highest bacterial density (see Table 5). Advantages of this particular fabric over the others tested include light weight and flexibility, less degradable, and it had a relatively higher surface areu providing for broader environmentul conditions for microbial growth. Lee and Shoda 29 also found that unwoven fabrics outperform fibrous fabrics in the removal of methanethiol.

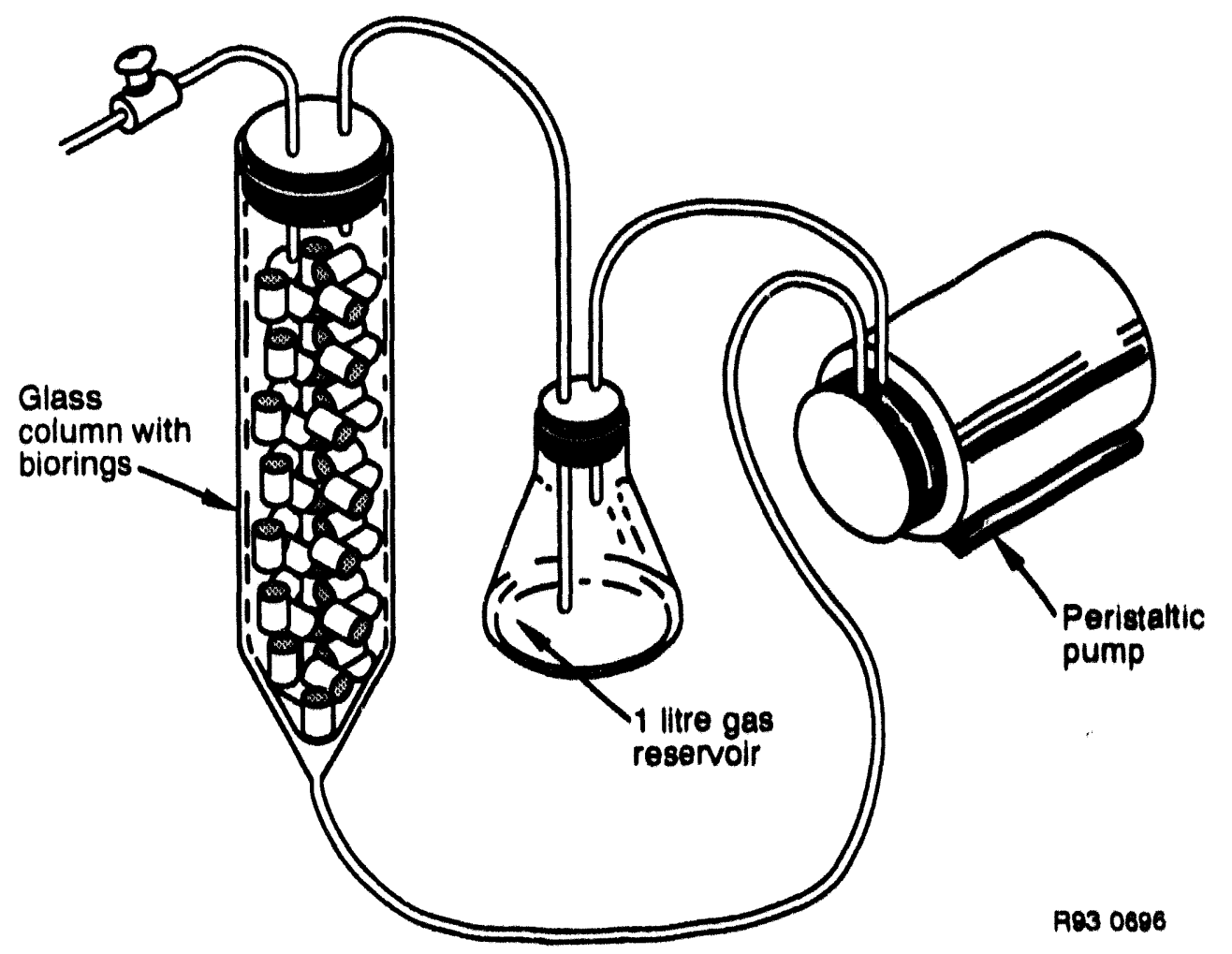

Figure 17. Schematic diagram of gas phase bioreactor. 


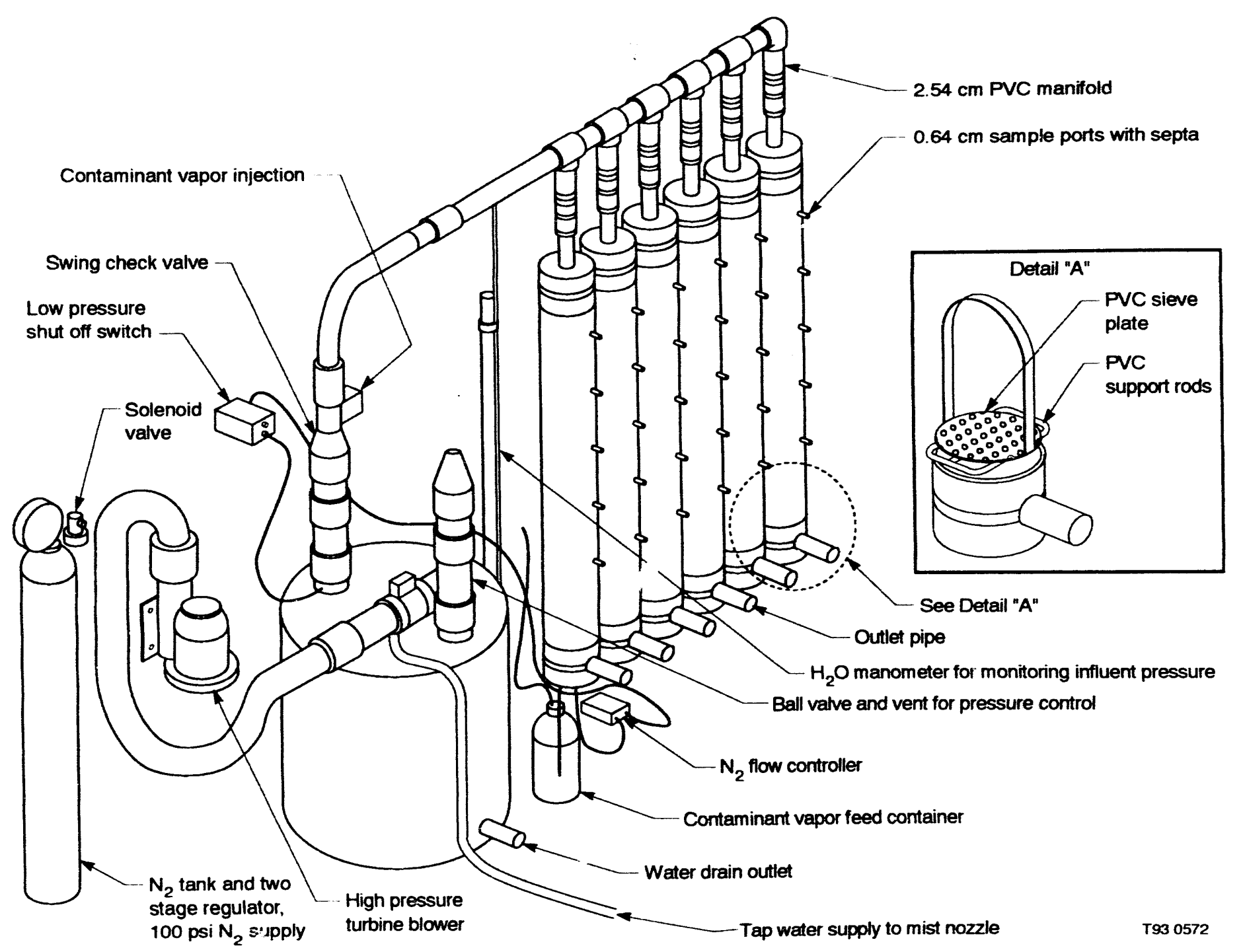

Figure 18. Bioreactor test system. 


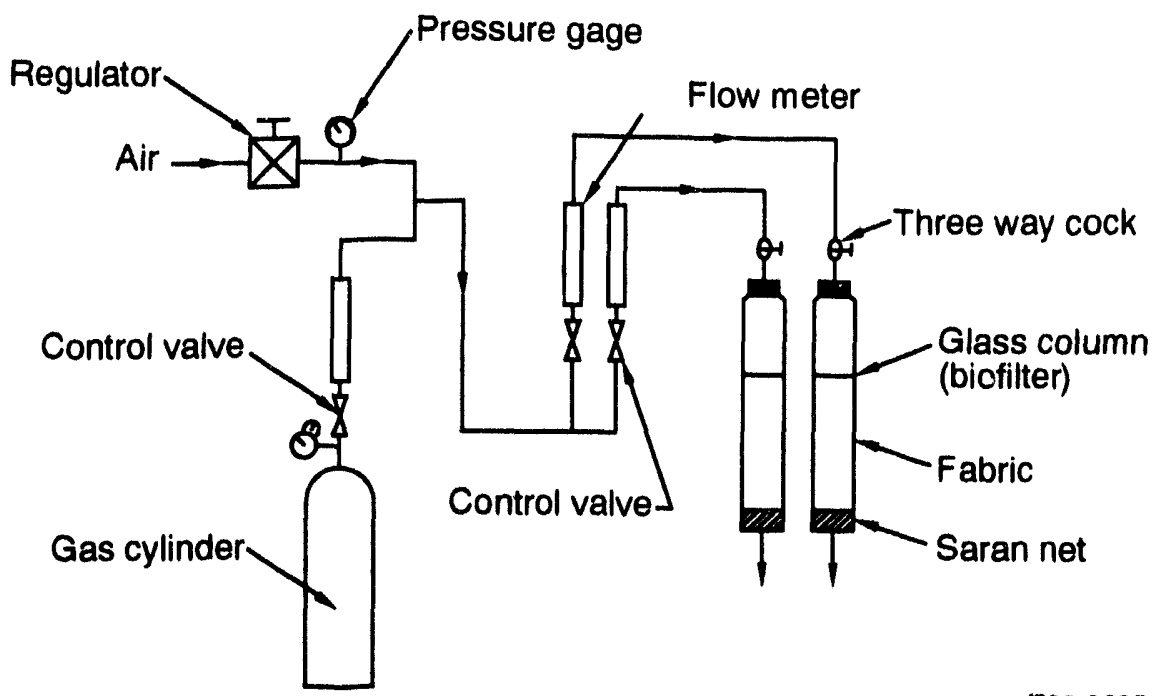

R93 0625

Figure 19. Schematic diagram of the laboratory-scale fabric biofilter system.

Table 3. Maximum removal rates of DMS in different fabric biofilters.

\begin{tabular}{|c|c|c|c|}
\hline & \multirow[b]{2}{*}{ Packing materials } & \multicolumn{2}{|c|}{ Parameters } \\
\hline & & $V_{m}^{a}$ & $\mathrm{~K}_{\mathrm{s}}^{\mathrm{b}}$ \\
\hline & Rayon & 0.50 & 3.67 \\
\hline & Acryl & 0.45 & 3.14 \\
\hline & Polyester & 0.83 & 1.83 \\
\hline & Asgard & 1.33 & 8.68 \\
\hline & FN-200CF-15 & 2.28 & 6.28 \\
\hline & FN-200AC & 1.16 & 5.80 \\
\hline & FN-300PP-15 & 1.08 & 6.27 \\
\hline & FN-300PS-15 & 0.64 & 2.91 \\
\hline & FH-150PE-15 & 0.66 & 3.24 \\
\hline & Peat (2) & 0.38 & 10.00 \\
\hline & Polypropylene (6) & 0.34 & 3.40 \\
\hline & Nylon (6) & 0.47 & 4.10 \\
\hline & $y$ fab./d. & & \\
\hline & & & \\
\hline
\end{tabular}


Table 4. Compositions of media used for bacterial countings.

\begin{tabular}{lllllll}
\hline $\begin{array}{c}\text { Name of } \\
\text { media }\end{array}$ & \multicolumn{2}{c}{$\mathrm{MW}$} & \multicolumn{2}{c}{ DMSO } & \multicolumn{2}{c}{ Nutrient-agar } \\
\hline Compositions & $\mathrm{KH}_{2} \mathrm{PO}_{4}$ & 3 & $\mathrm{~K}_{2} \mathrm{HPO}_{4}$ & 1.55 & $\left.\mathrm{Na}_{2} \mathrm{HPO}_{4} .12 \mathrm{H}_{2} \mathrm{O}\right)$ & 2 \\
$(\mathrm{~g} / \mathrm{L})$ & $\mathrm{NH}_{4} \mathrm{Cl}$ & 0.1 & $\mathrm{NaH}_{2} \mathrm{PO}_{4}$ & 0.85 & $\mathrm{NaCl}$ & 3 \\
& $\mathrm{MgSO}_{4} .7 \mathrm{H}_{2} \mathrm{O}$ & 0.5 & $\left(\mathrm{NH}_{4}\right)_{2} .5 \mathrm{SO}_{4}$ & 0.1 & Yeast extract & 3 \\
& $\mathrm{CaCl}_{2} .2 \mathrm{H}_{2} \mathrm{O}$ & 0.3 & $\mathrm{NH}_{4} \mathrm{Cl}$ & 2 & Meat extract & 3 \\
& $\mathrm{FeSO}_{4} .7 \mathrm{H}_{2} \mathrm{O}$ & 0.01 & $\mathrm{FeSO}_{4} .7 \mathrm{H}_{2} \mathrm{O}$ & 0.01 & Peptone & 15 \\
& $\mathrm{Na}_{2} \mathrm{~S}_{2} \mathrm{O}_{3} .5 \mathrm{H}_{2} \mathrm{O}$ & 8 & Yeast extra & 0.1 & Agar & 20 \\
& $\mathrm{Gellan} \mathrm{gum}$ & 5 & DMSO & 1 & & \\
& & & Gellan gum & 5 & & \\
& & & & & & \\
& & & & & & \\
& & &
\end{tabular}

Table 5. Bacterial counting in different media.

\begin{tabular}{lccc}
\hline & \multicolumn{3}{c}{ Media (cfu/dry-fab.) ${ }^{a}$} \\
\cline { 2 - 4 } Packing materials & DMSO & MW & NA \\
\hline Rayon & $1.7 \times 10^{8}$ & $1.05 \times 10^{8}$ & $5.1 \times 10^{7}$ \\
Acryl & $4.1 \times 10^{8}$ & $3.52 \times 10^{8}$ & $4.1 \times 10^{8}$ \\
Polyester & $4.42 \times 10^{8}$ & $3.89 \times 10^{8}$ & $4.15 \times 10^{8}$ \\
Asgard & $3.25 \times 10^{8}$ & $2.84 \times 10^{8}$ & $2.27 \times 10^{8}$ \\
FN-2(K)CF-15 & $8.76 \times 10^{9}$ & $1.29 \times 10^{10}$ & $8.64 \times 10^{9}$ \\
FN-2(K)AC & $2.64 \times 10^{9}$ & $2.87 \times 10^{9}$ & ND \\
FN-3(K)PS-15 & $3.47 \times 10^{9}$ & $2.45 \times 10^{9}$ & $2 .\left(14 \times 10^{9}\right.$ \\
FH-15()PE-15 & $2.99 \times 10^{9}$ & $2.11 \times 10^{9}$ & $1.32 \times 10^{9}$ \\
FN-3())PP-15 & $1.96 \times 10^{9}$ & $2.85 \times 10^{9}$ & ND \\
& & & \\
a. Colony forming units/dry fabric. & & \\
b. Nol determined. & & & \\
\hline
\end{tabular}




\section{SOLVENT DEGRADATION}

Numerous organic solvents have been identified as soil and water contaminants. The route of travel from soil is either via volatilization or entry into the ground water. Several physical techniques for vapor removal from soil and water involve vapor-phase extraction or gas stripping. Both methods remove volatiles from soil and water by transferring them to air via decreased pressure. After transfer into the gas phase, volatilized organic compounds can be treated biologically using methods discussed in previous sections. Solvent removal from contaminated water is complicated by the immiscibility of most solvents in water as well as potential toxic effects on microorganisms at high concentrations. Gas phase and trickling filters are commonly used as bioreactor designs because of their increased surface area, thus allowing increased mass transfer.

Many chlorinated solvents can be degraded by methanotrophic bacteria because of their ability to cometabolize these chemicals with methane. Methane however remains a preferred substrate and can reduce the degradation rates of solvents through competitive inhibition. Although methane is needed for enzyme induction, Speitel and Leonard ${ }^{30}$ have used methanotroph physiology in developing a sequencing biofilm bioreactor that minimizes competitive inhibition from methane and increases chlorinated solvent degradation rates. The bioreactor design enuploys two modes of operation consisting of a growth mode and a degradation mode. During the growth mode (see Figure 20), methane and oxygen were supplied in

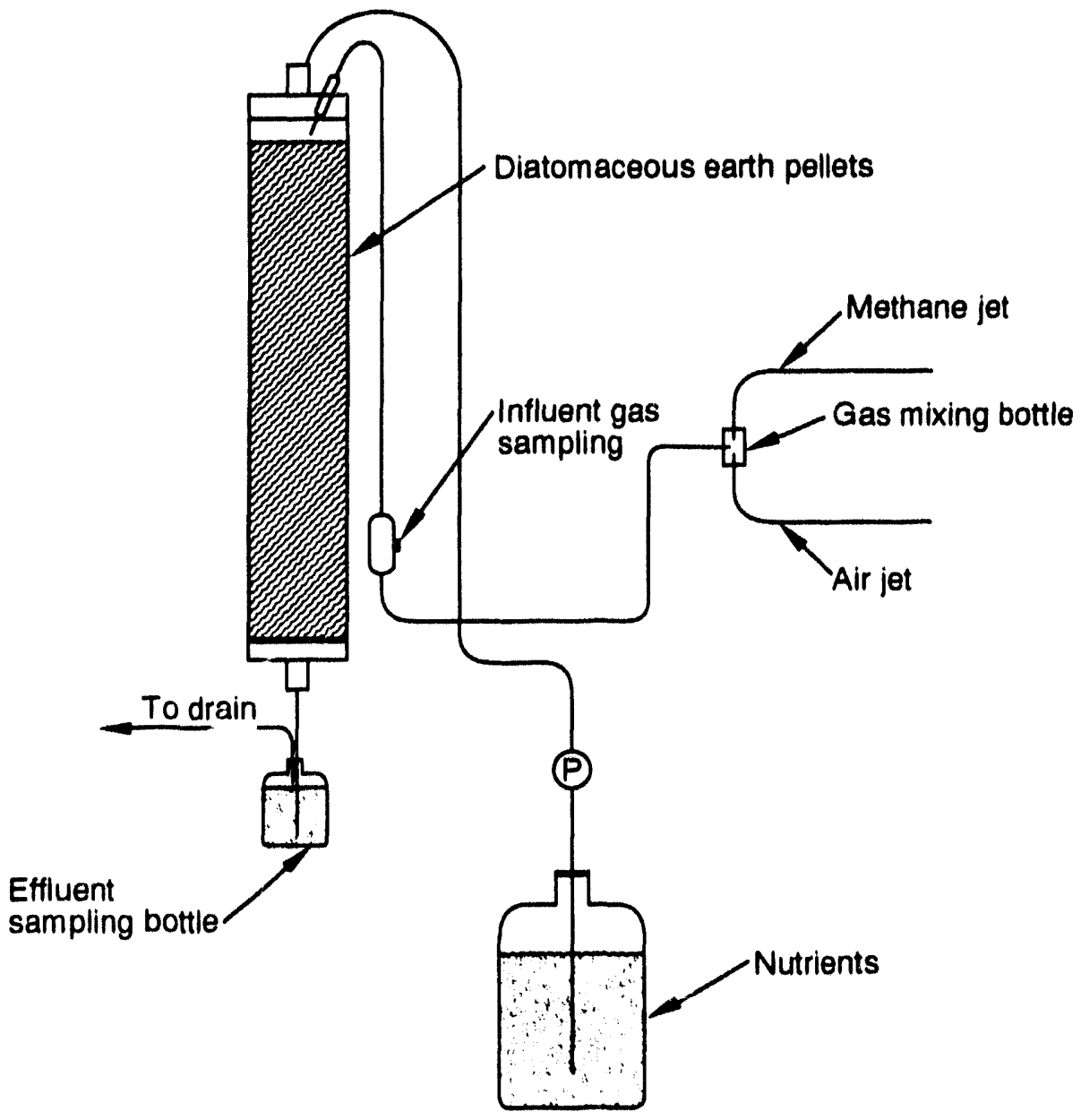

Figure 20. Schematic of sequencing reactor during growth mode. 
the gas phase to the organisms. This allowed for increased biomass in the bioreactor and induction of nonspecific enzymes essential for solvent degradation. The degradation mode (see Figure 21) involved filling the bioreactor with water containing formate as a source of energy for chemical reducing power, and chloroform as a model chlo- rinated compound. Although this bioreactor design and operation have not been optimized, the authors demonstrated significantly belter results with the sequencing bioreactor than a packed-bed, continuous flow bioreactor, due primarily to the increased biomass permitted in the sequencing bioreactor.

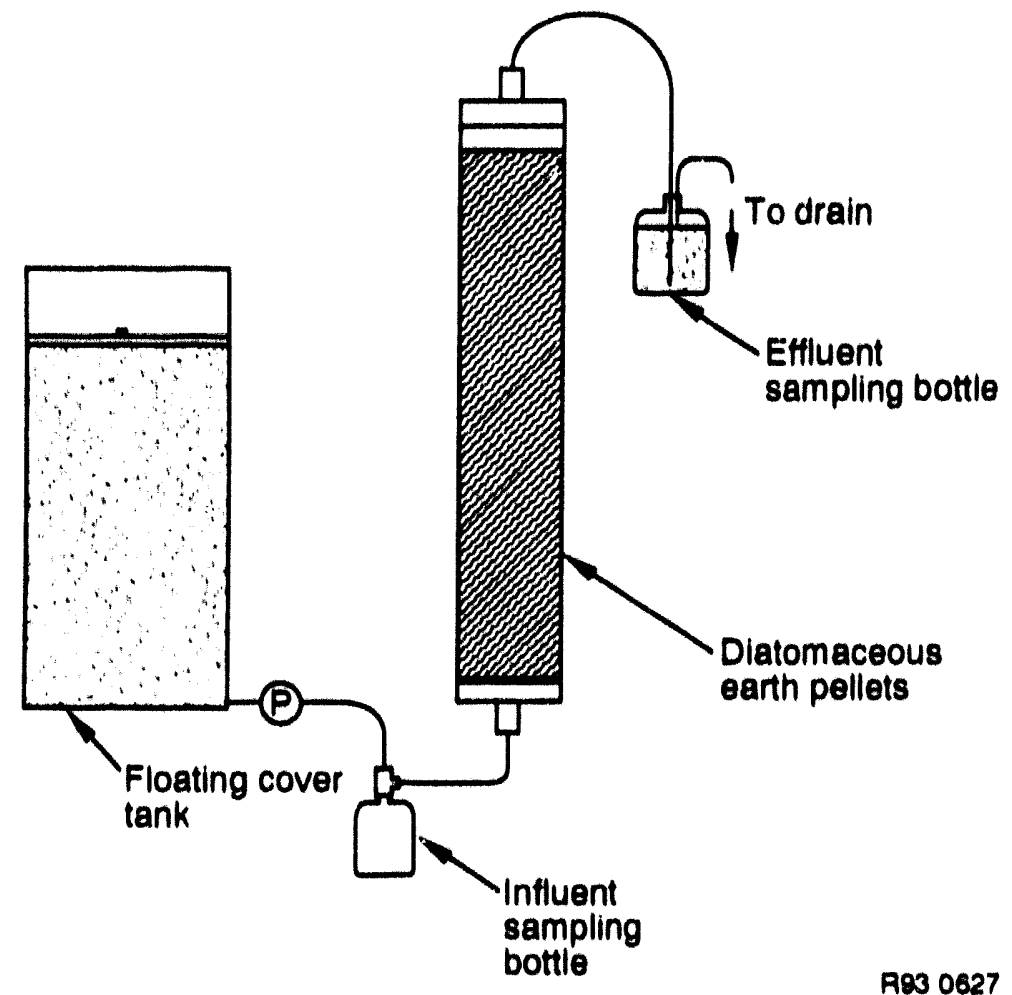

Figure 21. Schematic of sequencing reactor during degradation mode. 


\section{CELL IMMOBILIZATION STRATEGIES}

In order to operate bioreactors at high dilution rates and separate cells from by-products, immobilized cell technologies have been employed in numerous situations. These techniques can be categorized into iwo general groups: cells altached to a solid support medium, thereby forming a biofilm: and cells (or enzymes) embedded into a solid or semisolid matrix such as gel beads. Important properties of support media include porosily, leaching ability, and surface roughness.

Problems associated with immobilized cell bioreactors include:

- Clogging caused by increased cell biomass

- Unstable bed expansion caused by imbalanced cell growth

- Accumulation of dead cell mass

- Gas entrapment inside the bioreactor

- Nutrient channeling as in trickle bed bioreactors

- Cell leakage of gel disintegration associated with immobilized cells in gel beads.
Lewis and Yang ${ }^{31}$ have demonstrated a packed bed bioreactor for continuous propionic acid fermentation employing a spiral wound, fibrous bed bioreactor (sec Figure 22). The cells, Propioni. hacterium acidipropionici ATCC 4875, were attuched to the fibers and entrapped in the void volume inside the matrix of the material. The fibrous material was made from a piece of cotton lowel, overlaid with stainless steel mesh. This matrix was spirally wound around the vertical axis with a $5 \mathrm{~mm}$ gap between layers and placed in a glass column on lop of ceramic supports. Void volume was approximately 9()$\%$. Bacterial density approached $37 \mathrm{~g} / \mathrm{L}$. while productivity of this bioreactor approached four times that of batch systems for 4 months without problems from contamination, clogging, or degeneration.

A number of solid supports, including baked clay and melted slug were used for methanogens by Nishio et al. ${ }^{32}$ to retain the cells in bioreactors fed acetate and formate for increased methane production efficiency. Hydraulic retention times were shortened from $18 \mathrm{~h}$ in chemostat culture 10 $0.4 \mathrm{~h}$ in fixed bed culture with formate and 6.71 days to (0.15 days with acetale (see Table 6).

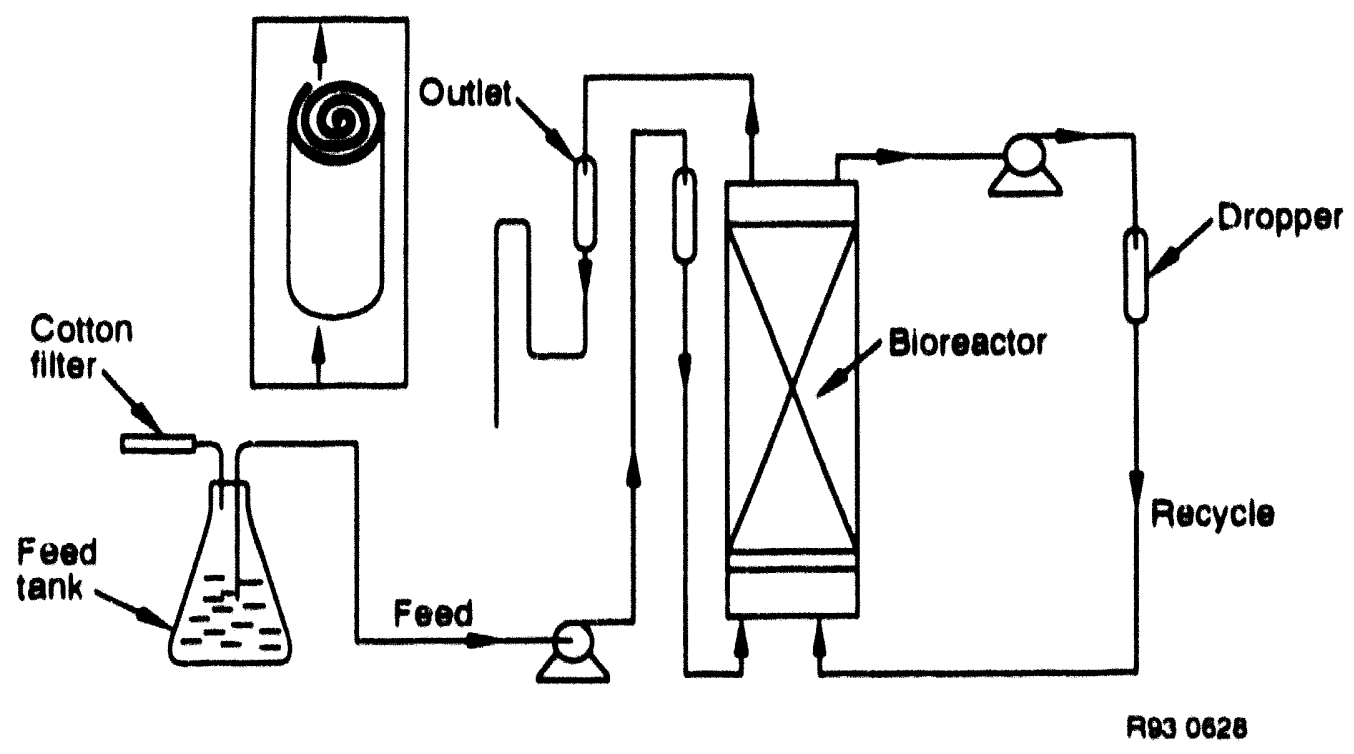

Figure 22. Experimental packed bed bioreactor apparatus. 
Table 6. Methane fermentation from formate in fixed-bed reactor."

\begin{tabular}{|c|c|c|c|c|c|}
\hline Support material & $\begin{array}{c}\text { Formute } \\
\text { consumption } \\
\text { rate } \\
\text { (mmol/L-day) }\end{array}$ & $\begin{array}{c}\text { Methane } \\
\text { production } \\
\text { rate } \\
\text { (mmol/L-day) }\end{array}$ & $\begin{array}{l}\text { Hydraulic } \\
\text { relention } \\
\text { lime } \\
\text { (h) }\end{array}$ & $\begin{array}{c}\text { Cell } \\
\text { concentration } \\
(\mathrm{g} / \mathrm{L})\end{array}$ & $\begin{array}{l}\text { Methane } \\
\text { yield } \\
\text { (mol/mol) }\end{array}$ \\
\hline Zeolite No. 3 & 3.587 & 6.39 & 0.7 & 19.2 & 0.18 \\
\hline Glass beads & 96 & 20 & 4.6 & N'T & 0.22 \\
\hline Baked clay & 6.717 & 1.720 & 0.4 & 20.1 & 0.26 \\
\hline Melted slug & $4,166.5$ & 1.010 & (1.6 & 14.9 & 0.25 \\
\hline Cellulose acetate fiber & 1.870 & 475 & 1.7 & 5.80 & 0.26 \\
\hline Activated carbon fiber & 1.761 & 380 & 1.5 & 5.81 & 0.22 \\
\hline Sponge rubher & 213 & 14 & 4.1 & ND' & 0.16 \\
\hline None $b$ & 161 & 37 & I8 & 0.07 & 0.23 \\
\hline \multicolumn{6}{|c|}{ a. Steady stute dat i ohtuined at a nearly critical dilution rate. } \\
\hline \multicolumn{6}{|c|}{ b. Chemostat culture withoul fixed bed. } \\
\hline c. Nol delermined. & & & & & \\
\hline
\end{tabular}

Porous microcarriers for melhanogens ine Tahle 7 , when compured 10 sand were shown by Yee el al. "10 the superior in their cell relention capacily (sec Table $X$ ) because of increased surface area, lotal pore volume. and mean pore diam. eler. therehy increasing bioreactor efficiency and decreasing sturtup lime.

Penicillinase and lactale dehydrogenase were immobilised in a ceramic membrane microfiller consirucled from alpha alumina particles. it the substrale solution permeuted the membrane and reacted with the engymes inside. Figure $2.3 \mathrm{dem}$. onstrales how the hioreactor was operaled. where $S_{1}, V_{R}$, and $V_{1}$ are reservoir concentralion, hioreactor volume, and reservoir (lanh) volume. respectively. Neither mass iransfer effects or shear effects were observed during operation of this hioreactor. This hioreacour design may be desiruble when an immobilized enayme has a high aclivity and a low Michaclis constant.
Glucoumylase was immobilized by Pieters el al. ${ }^{35}$ onto magnetic particles for mallodextrin hydrolysis therehy allowing for particle recovery with un electromagnet.

Backer el al. "h developed a method wherehy gel-immobilized cell sysiems can be anulyaed for the effects of diffusional limilations and heteroge neous cell distribulion. The syslem lsee Figure 24) is a gel membrane hioreacior and sim. ulates reaction and diffusion ill a gei head. The top of the gel equales to the outside of a get head while the bottom of the gel simulates llie inner gel bead. Sumpling chumbers at the top and hollom (outer and inner) of the gel permir liquid und gas analysis. In this way the gel membrane bioreactor can be used for the study of diffusion and cellular reaction in a gel-immobilized cell system. which can subseyuenily lead io a mathermatical model for sutistrate and cell concentrations in the gel matrix. 
Table 7. Microcarrier characteristics."

\begin{tabular}{|c|c|c|c|c|}
\hline & $\mathrm{R} \mathrm{I}^{\mathrm{H}}$ & $\mathrm{R} 2$ & R.3 & R4 \\
\hline Specific gravily & 2.21 & 2.36 & 2.27 & 2.6 .5 \\
\hline Dry bulk densily (g/mL) & 0.44 & 0.31 & 0.46 & 1.93 \\
\hline Surface area (mi/g) & 46 & 1.3 & 0.2 & $0.10(4)$ \\
\hline Pore volume (mi/g) & 1.19 & 1.47 & (1).66 & - \\
\hline \multicolumn{5}{|l|}{ Volume fraction (mi/g) } \\
\hline $0 .(14-0.1 \mu \mathrm{m}$ & 0.23 & 0.01 & - & - \\
\hline $0.1-1.0 \mu \mathrm{m}$ & 0.29 & (0.14 & $0 .(12$ & $-\ldots$ \\
\hline $1.0-10.0 \mu \mathrm{m}$ & 0.28 & 0.88 & 0.10 & - \\
\hline $10 .(1-.50 .0 \mu \mathrm{m}$ & 0.12 & 0.54 & 0.47 & - \\
\hline Mean pore diameter $(\mu \mathrm{m})$ & 0.14 & 6.5 & 310.9 & - \\
\hline \multicolumn{5}{|c|}{ a. Microcumrier size: $425-610 \mu \mathrm{m}$. } \\
\hline \multicolumn{5}{|c|}{$\begin{array}{l}\text { 6. R1: Calcined diatomaceous earth and clay. } \\
\text { R2: Flux culcined diatomaceous earth. } \\
\text { R.: Culcined diatomaceous earth and clay. } \\
\text { R4: Ollawa silicu sund. }\end{array}$} \\
\hline
\end{tabular}

Table 8. Average pseudo-steady-state reactor performance al an organic loading of o g. TCC: $1 /$ day.

\begin{tabular}{|c|c|c|c|c|}
\hline & RI & $\mathbf{R} 2$ & R.I & Rt \\
\hline HRT (h) & 20 & 20 & 20 & 20 \\
\hline Feed TOC (mg/h.) & $5,(x \times)$ & $s,(x)$ & $S,(x)$ & $s,(x x)$ \\
\hline Effluent TOC $(m g / h)$ & $s(1)$ & 411 & 411 & 1.50 \\
\hline Percen $T(X$ removal & 49 & 49 & yy & 97 \\
\hline \multicolumn{5}{|l|}{ Immohilized cell } \\
\hline Concentrution $(g / h)$ & 15.4 & $4(1), 0$ & 20.7 & 5,11 \\
\hline Muns (g) & 0.7 & 17.4 & 9.11 & 2.2 \\
\hline Percenl of holal cell mans & 41 & $y 9$ & 48 & (1) \\
\hline \multicolumn{5}{|l|}{ Free cell } \\
\hline Concentrulion $(m p / h)$ & 3.36 & 147 & 42 & 278 \\
\hline Mass (p) & $11.6 x$ & 0.29 & $0.1 \mathrm{x}$ & 0.56 \\
\hline Percent of total cell mass & $y$ & 1 & 2 & 211 \\
\hline
\end{tabular}


Table 8. (continued).

\begin{tabular}{|c|c|c|c|c|}
\hline & RI & $\mathrm{K} 2$ & R.3 & R4 \\
\hline \multicolumn{5}{|l|}{ Methane production } \\
\hline Yield (I CH/g TOC) & 1.01 & 0.9 .5 & 1.0 .5 & 0.97 \\
\hline Percent of biogas & 6.5 & 70 & 6.5 & 70 \\
\hline MCRT (days) & 38 & 226 & 188 & 1.5 \\
\hline $\begin{array}{l}\text { Observed cell deluchmenl rate } \\
\text { (g VSS/4 TOC) }\end{array}$ & 0.055 & 0.026 & 0.025 & 0.1604 \\
\hline \multicolumn{5}{|c|}{$\begin{array}{l}\text { R1: Calcined diatomaceous earth and clay. } \\
\text { R2: Flux calcined diatomaceous earth. } \\
\text { R3: Calcined diafomaceous earth and slay. } \\
\text { R4: Oltawa silica sand. }\end{array}$} \\
\hline
\end{tabular}

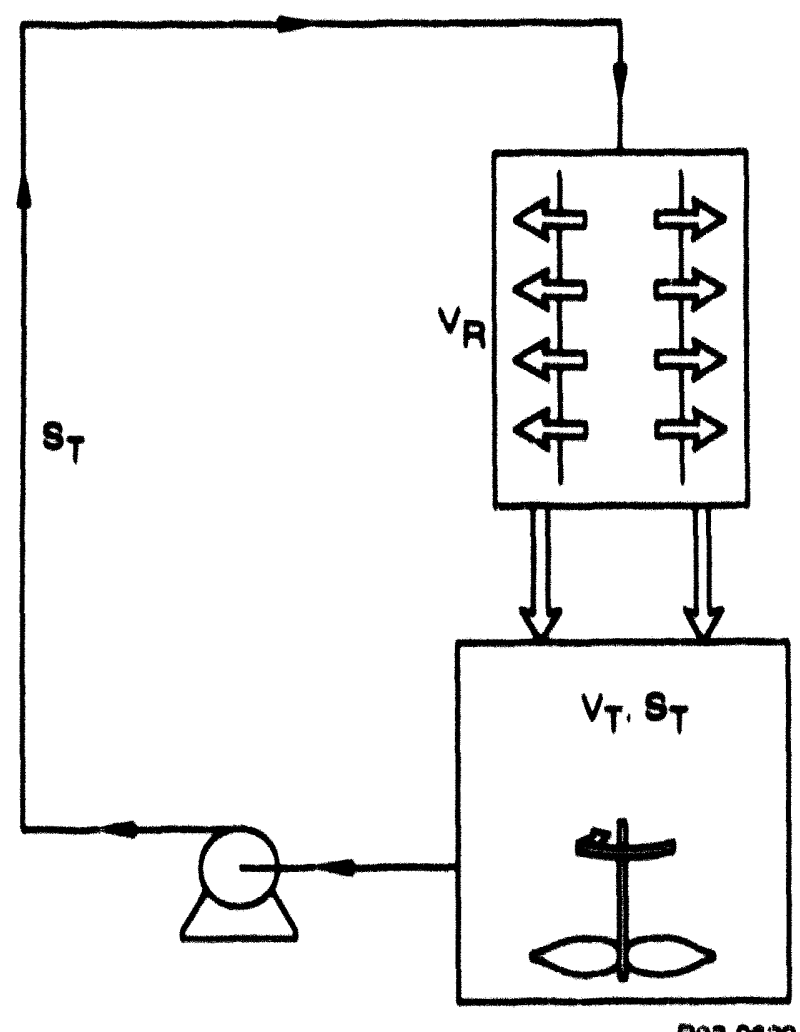

Figure 23. Ceramic microfilter reactor in dead-end conliguration under batch-recycle uperalion. 


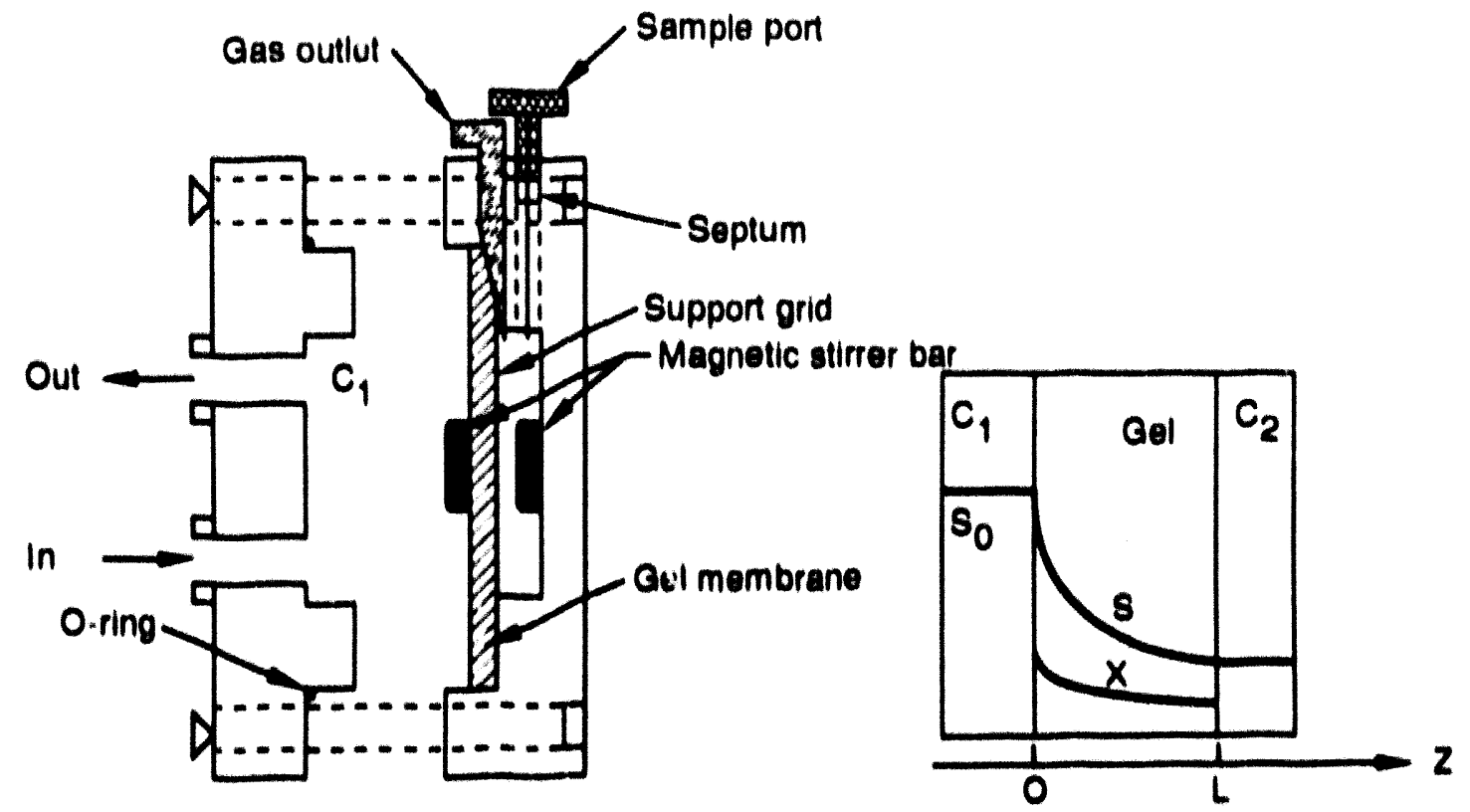

C, First stirred chamber (open)

$C_{2}$ Second stirred chamber (closed)

S - Substrate concentrations

$S_{0}$ - Substrate concentration in chamber $C_{1}$

$x$ - Immobilized biomass concentrations

0 Time $=0$

L Membrane thickness

$Z=$ Time $>0$

LOS 0001

Flgure 24. The gel membrune reactor. 


\section{PHOTOBIOREACTORS}

Removal of carbon dioxide from industrial sources has heen accomplished with the use of photosynthetic microorganisms. Although carloon dioxide is highly waler soluble and poses little problem in muss transfer, the limiting factor in these systems is often light penetration through the bioreactor. Lee and Low ${ }^{17}$ operaled a bioreacfor tilted at an angle facing the sun fo increase solar radiation to the bioreacior and increase hiomass yields relative 10 controls (sec Figure 29). Results demonstrated that a photobioreactor operaled at 8()-degrees had a daily hiomass oulput six times that of similar hioreactors operated in a horizontal position. Enhanced light penetration into a photobioreactor was accomplished with optical fibers. "K Light energy disiribution was accom. plished hy passing light through a bundle of optical fibers inside a column-lype bioreactor (see Figure 26). The light was in the visible region of the spectrum $(38(2)-7(X) \mathrm{nm})$ with little infrared und reduced UV, from a $A(X) W$ metul hulide lump. This light diffusing optical fiber photohioreactor demonstrated pelential for $\mathrm{CO}_{2}$ removal and hio. mass produclion using marine algae.
Famiglietli el al. ${ }^{34}$ contained the blue-green algate (Anabar'na varabilis) in waler-in-oil microemulsions containing ('Tween8.5/Spant())/ hexadecane/water. ihe re..oll was a homogeneous microhial solution (cell density - $10^{\mathrm{K}}$ cells $/ \mathrm{mL}$ ) will photosynthelic activity laking place inside the emulsions because of their transparent nature. The emulsions also significuntly prevented sedimentation of the cells when compared to unemul. sified controls (see Figure 27).

Khan el al. "1 have demonstrated enhanced rates of hydrogen production compared io that of solar photovoltaic hydrogen systems hy incorporating a hiopholoclectrochemical system. This system uses hacteriorhodopsin in the purple membranes of Halobacterium halobium $\mathrm{MMT}_{22}$. which is a light driven proton pump. H. halohium also produces hydrogen. The biophotoclectrochemical system (see Figure 2x) consisis of Iwo chambers filled with a NaCl electrolyte solution and sepurated by a sintered glass disc. $H$. halo. hium MMT22 is lexuled in one chamber und sup. porled hy a dialysis sack. This chumber also contains a silver and a platinum electrode

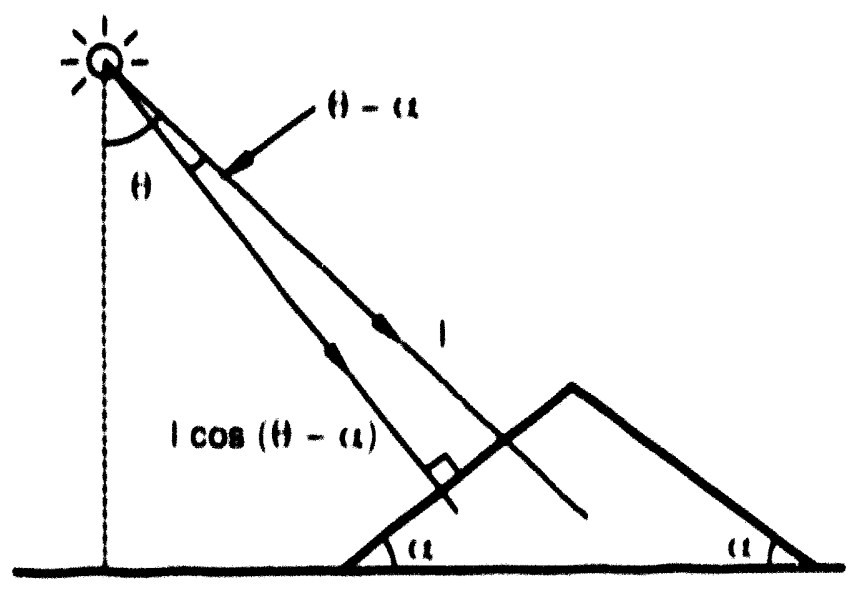

ค103 0631

Figure 25. Bioreacior inclines al an angle will the horiscontal. 


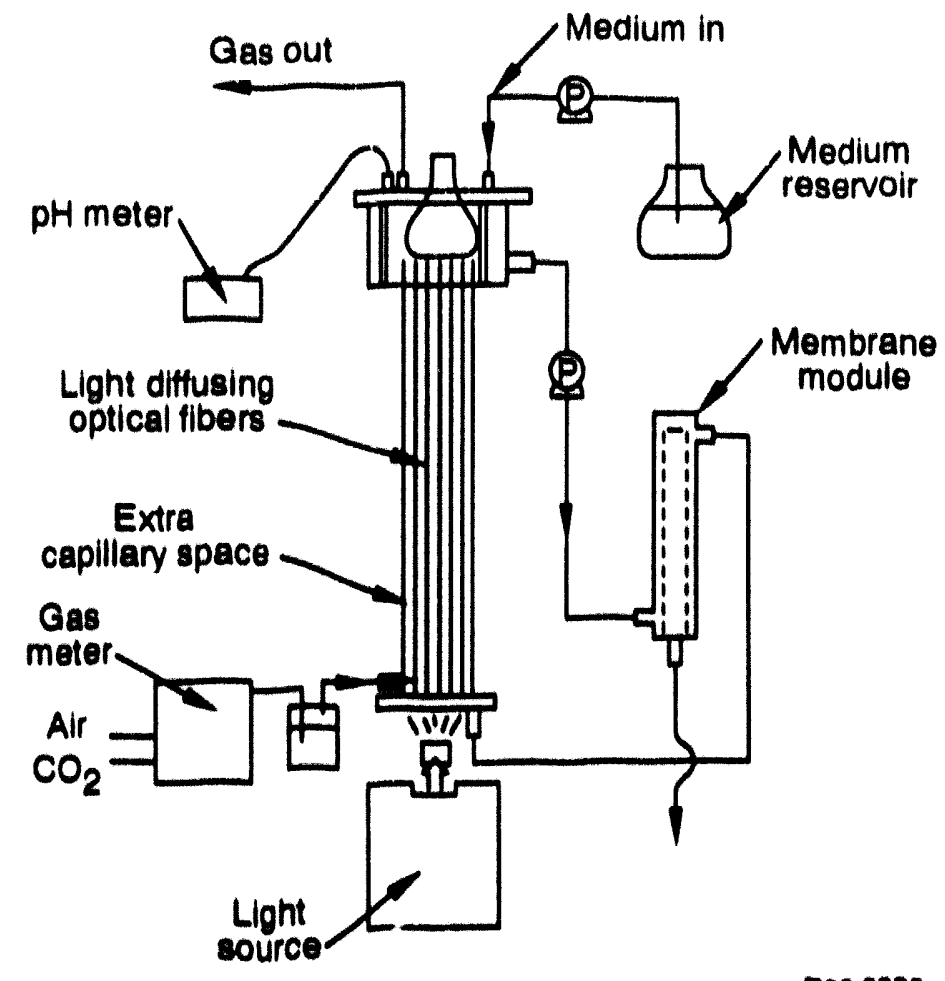

ค930358

Flgure 26. Schematic diagram of the light diffusing optical fiber photobioreactor system showing the ceramic membrane filtration module used for removing medium.

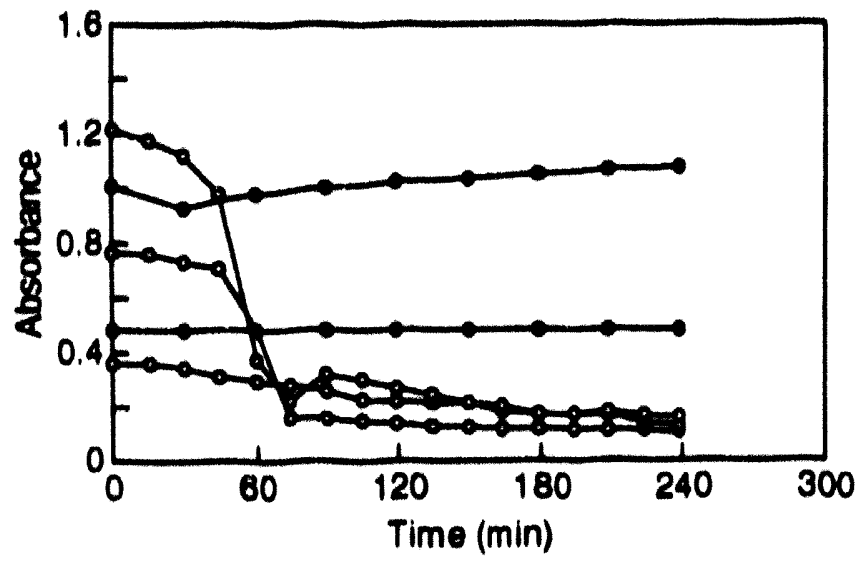

- A. variabilis in water

- - A. variabills in water-in-oll microemulsion

LQ30600

Figure 27. Sedimentation curves. 
(see Figure 28). The other chamber contains one $N / P$ silicone electrode with the $P$ side insulated and the $\mathrm{N}$ side platinum coated. The extemal driving potential is applied between platinum electrodes kept outside the dialysis sack and the silicone electrode. Current is measured as it passes through the silicone cell. The solar insulation at the surface of the bacterium is also noted by using a solorimeter. Illumination of the system ultimately results in protons from $H$. halobium $\mathrm{MMT}_{22}$ and electrons from silicone combining and producing hydrogen.

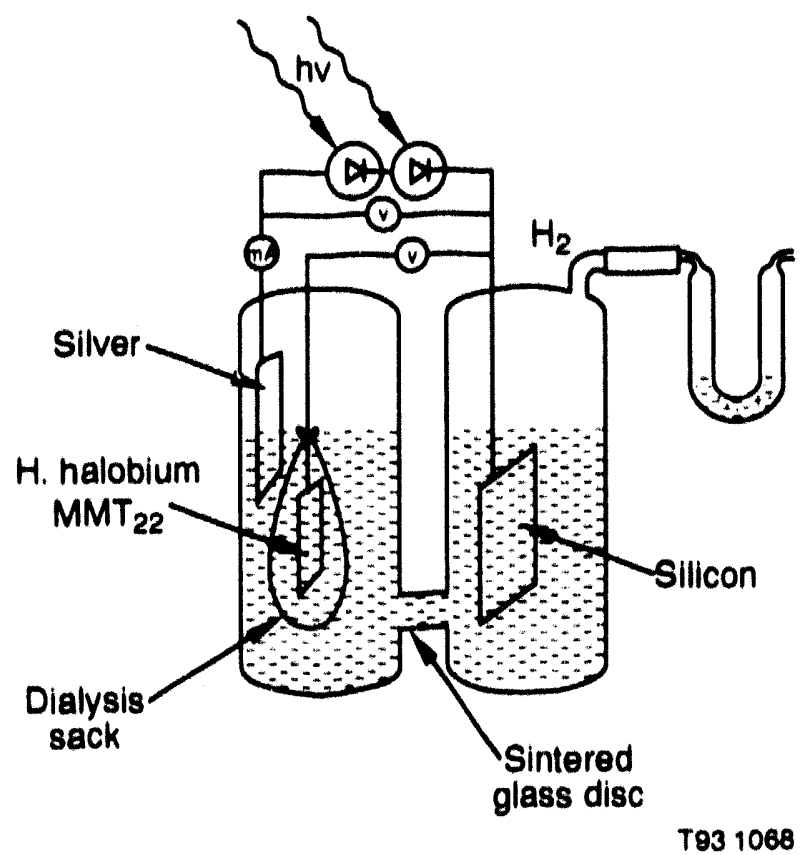

Figure 28. Schematic diagram of the apparatus used for solar hydrogen generation using Halohacterium halohium $\mathrm{MMT}_{22}$ and a silicon cell. 


\section{MICROBIAL INHIBITORS}

Microbial activity can be negatively affected by inhibitory substances entering as part of the feedstock. This is especially common when treating a complex waste stream. Anaerobic treatment is quite prone to inhibition becuuse of the sensitivity of parts of the microbial consortium, such as methanogens. Field et al. ${ }^{41}$ demonstrated methanogenic inhibition during woody biomass fermentation. Cohen ${ }^{42}$ surveyed several potential inhibiturs to methanogenesis. Field et al, ${ }^{41}$ added polyvinylpyrrolidone to liquid feedstocks before treatment to allow phenolics to bind with the polyvinylpyrrolidone and precipitate out.

Reduced performance in bioreactors can also be caused by metabolite inhibition. Buildup of microbial metabolites decreases bioreactor performance and often is caused by the inability to remove them from the bioreactor rapidly and economically. When these metabolites are of economic importance it is even more beneficial to remove them as rapidly as possible to minimize metabolite inhibition. This topic will be covered in the next section on by-product separation.

Several mathematical expressions were proposed by Thatipamala et al. ${ }^{43}$ to describe the following:

1. Growth rate as a function of substrate inhibition:

$\mu=\mu_{m}\left\{\frac{S_{\max }-s}{S_{\max }-S_{\min }}\right\}$

2. Instantaneous biomass yield as a function of product inhibition:

$Y_{1 / s}=\left(Y_{1 / s}^{0}-Y_{1 / s}^{m}\right)\left(\frac{1-P}{P_{m}}\right)^{n}+Y_{1 / s}^{m}$

3. Instantaneous biomass yield as a function of substrate inhibition:

$$
Y_{1 / s}=Y_{1 / 1}^{\prime \prime}\left\{\frac{S_{\max }-S}{S_{\max }-S_{\min }}\right\}
$$

4. Lag time caused by substrate inhibition:

$$
\frac{T_{1}}{\left(T_{1}\right)_{\min }}=\left(\frac{s_{0}}{s_{\min }}\right)^{\prime \prime}
$$

where

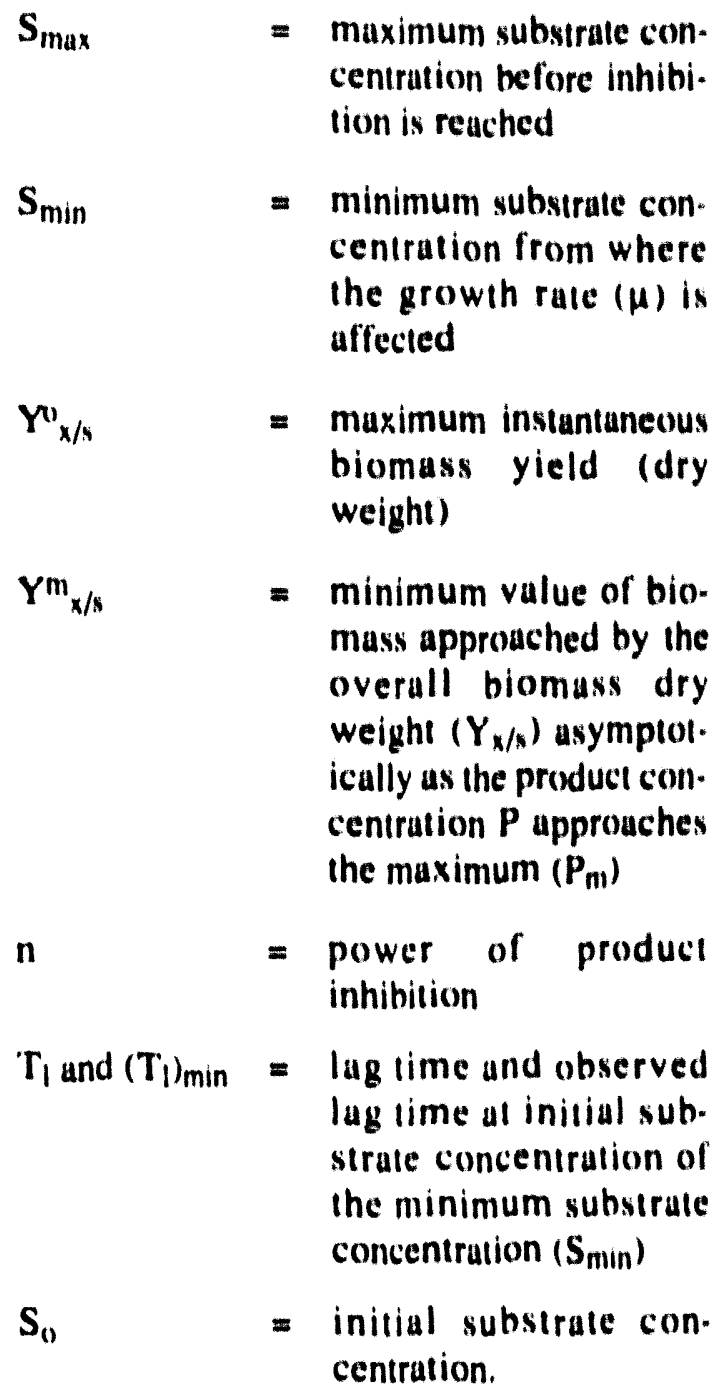

The removal of cresol from chemical mixtures containing nonphenolics was accomplished using a two-step process. ${ }^{4}$ This process involved cresol as a model phenolic and its conversion to UV. absorbing by-products via tyrosinase, followed by chitosan absorption of only the by-products of cresol conversion. This method was specific for cresol removal and did not react with other chemicals present, which were anisol and benzyl alcohol (see Figure 29). 


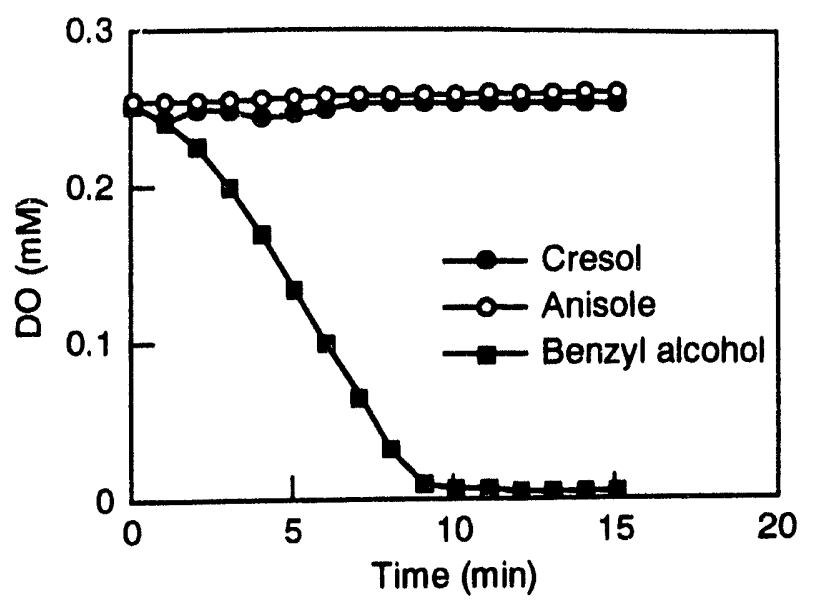

(a) (absence of $5 \% \mathrm{w} / \mathrm{v}$ chitosan)

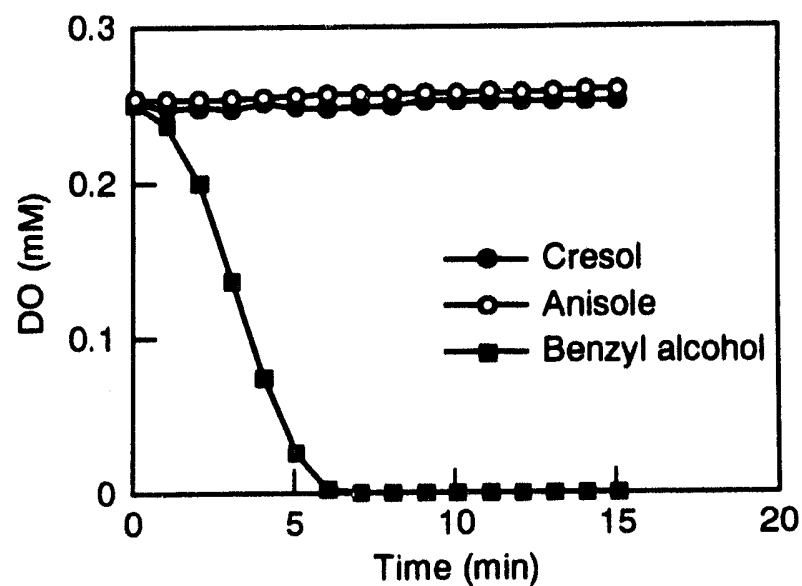

(b) (presence of $5 \%$ w/V chitosan) $\quad$ 2930599

Figure 29. Selectivity of the tyrosinase-catalyzed reaction for phenols. 


\section{BY-PRODUCT SEPARATION}

Desired by-products from a bioprocess can sometimes be separated easily because of their physical properties as gases or as precipitates. Other desired microbial metabolites remain in the liquid state and are difficult and expensive to remove. Many valuable chemical by-products need to be removed from bioreactors before they are transformed further to less valuable chemicals or initiate metabolite inhibition in the bioreactor. This problem reduces the cost-effectiveness of many bioprocesses. Removal of by-products from bioreactors has been accomplished in several ways (i.e., stripping, membrane solvent extraction, adsorption, pervaporation, electrodial. ysis, and liquid-liquid extraction).

Groot et al. ${ }^{45}$ recovered butanol from a fluidized bed bioreactor incorporating five separate separation techniques (see Figures 30-35). Substrate is supplied with the feed and the bleed prevents accumulation of cells, by-products, and salts. Biocatalyst particles are fluidized in the bioreactor using a recirculation stream (see Figure 30). One method of product separation employed a closed loop column containing Raschig rings, a condenser, and a compressor. Butanol volatility was increased by setting the column temperature to $70^{\circ} \mathrm{C}$, which also facilitated condensation of water and alcohol vapors (see Figure 31). Butanol removal from a fixed bed adsorber ${ }^{45}$ was also accomplished by using polymeric resin XAD8 as the adsorbent. In spite of the low adsorption capacity of this material compared to active carbon, medium components 'id not foul the resin and therefore can be reused. Silicalite has a high selectivity and capacity for butanol adsorption, ${ }^{46}$ but is prohibitive to use because of its high price. ${ }^{45}$ Andrews and Fonta ${ }^{47}$ analyzed ethanol production in a continuous, anaerobic bioreactor consisting of activated carbon, which facilitated ethanol removal in a circulating fluidized bed with about $10 \%$ of the ethanol produced (an inhibitory by-product) adsorbed to the carbon. Adsorption onto the activated carbon thereby decreases the ethanol concentration to the microbial biomass surrounding the activated carbon particle (see Figure 36). As biomass increases on the particle, inhibition is reduced and the particle moves to the bioreactor top, where it is removed for product recovery and then recycled back into the bioreactor.

Lactic acid removal from a biparticle fluidized bed bioreactor was possible because of the higher density of the sorbant particles (polyvinyl pyridine resin) compared to particles used to immobilize Lactobacillus delbreuckii ${ }^{48}$ (see Figure 37 ). This fluidized bed bioreactor allowed the denser, adsorbent particles to fall further down in the column where they were removed for product recovery while the cells immobilized onto the less dense particles stayed in the bioreactor column. This nonoptimized configuration was $c$,able of increasing the lactic acid yield by a factur of four.

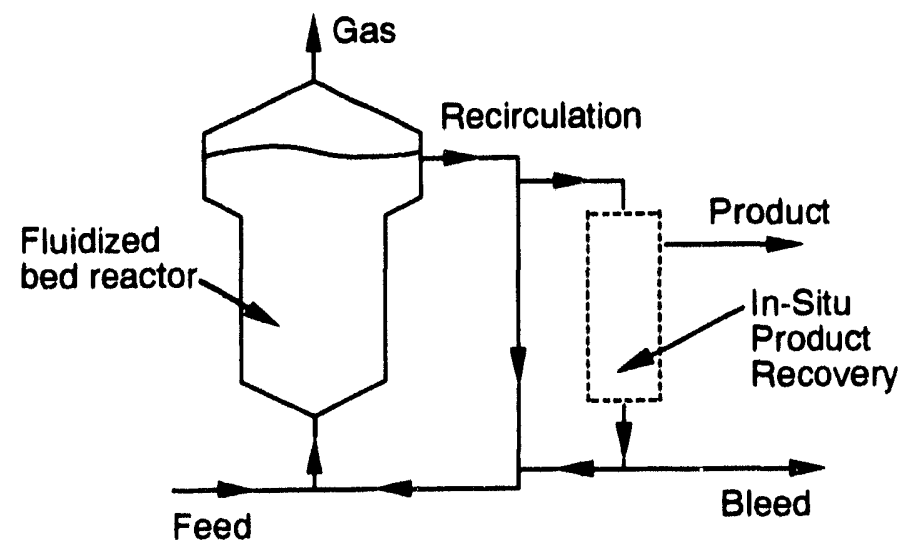

R930640

Figure 30. Integrated butanol production processes. Schematic of a fluidized bed reactor. 


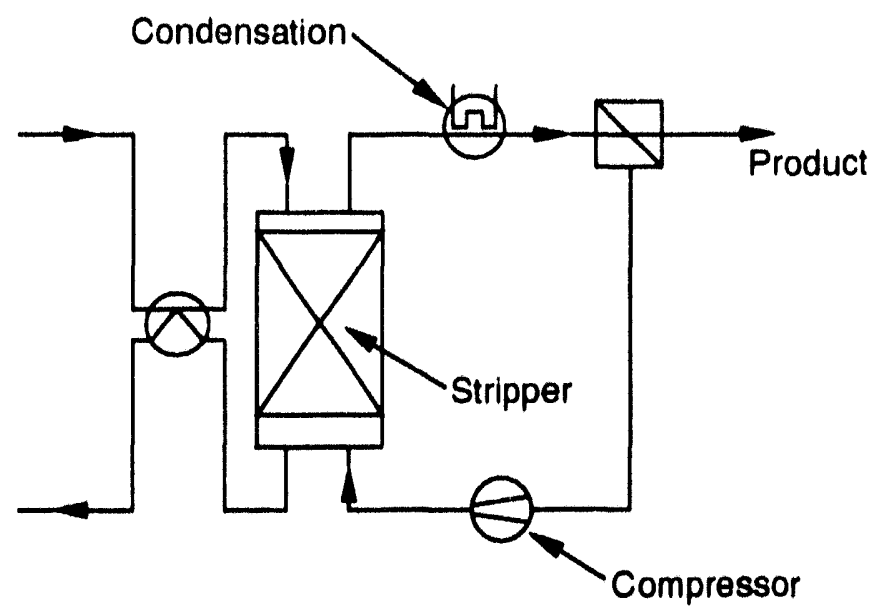

R93 0647

Figure 31. Schematic of a stripping process for in situ butanol recovery.

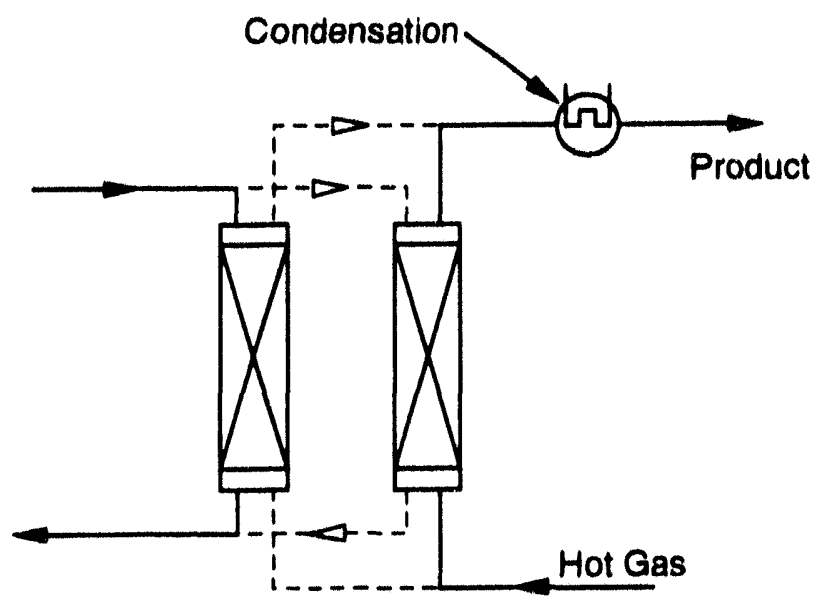

Adsorption Columns

R93 0650

Figure 32. Schematic of an adsorption process for in situ butanol recovery.

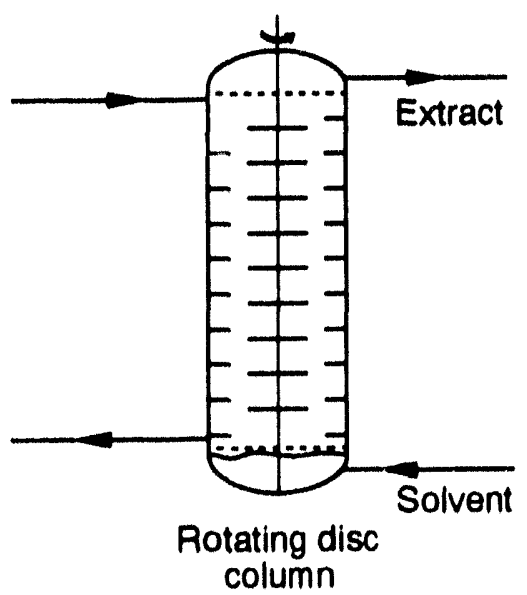

R93 0641

Figure 33. Schematic of a liquid-liquid extraction process for in situ butanol recovery. 


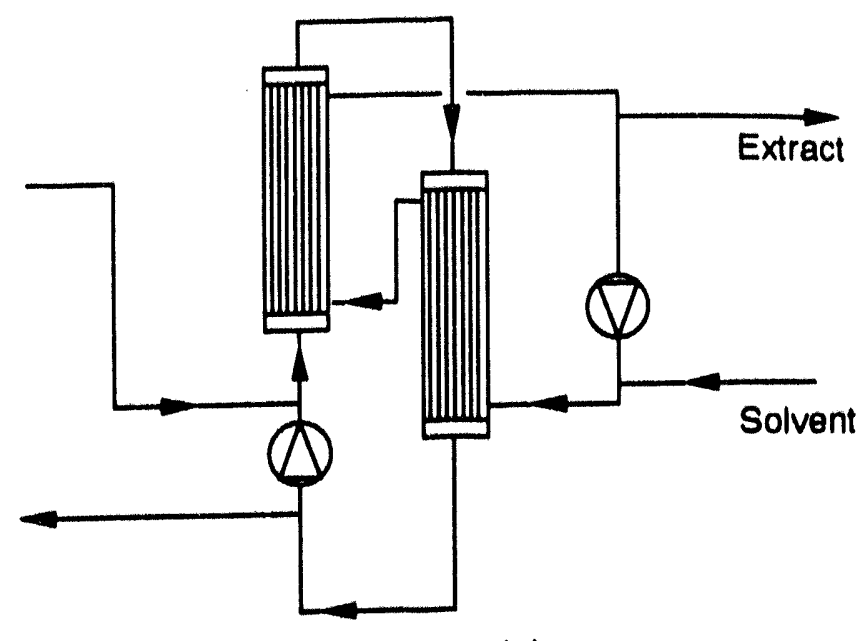

Pervaporation modules

L93 0597

Figure 34. Schematic of a pervaporation process for in situ butanol recovery.

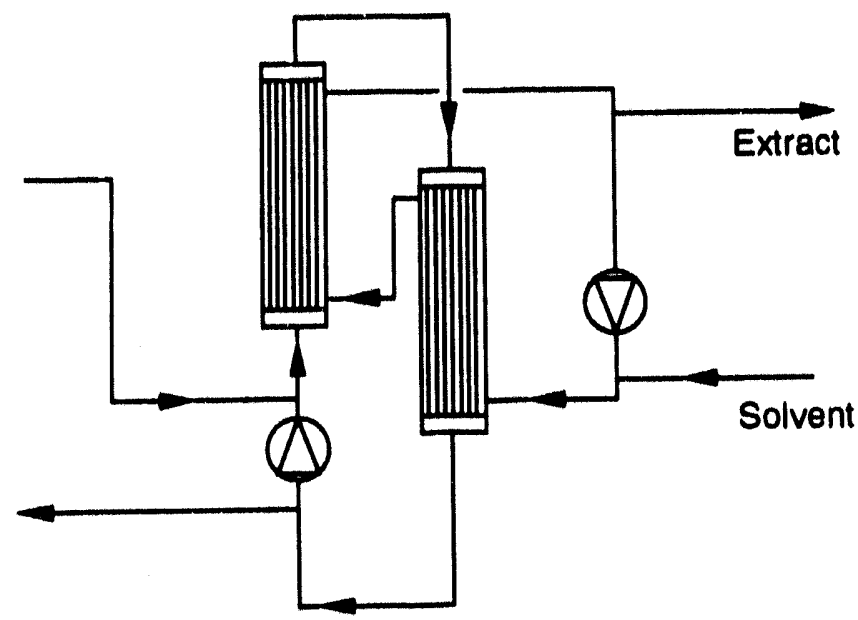

Perstraction modules

R93 0649

Figure 35. Schematic of a membrane solvent extraction process for in situ butanol recovery. 
(a) Thin Film

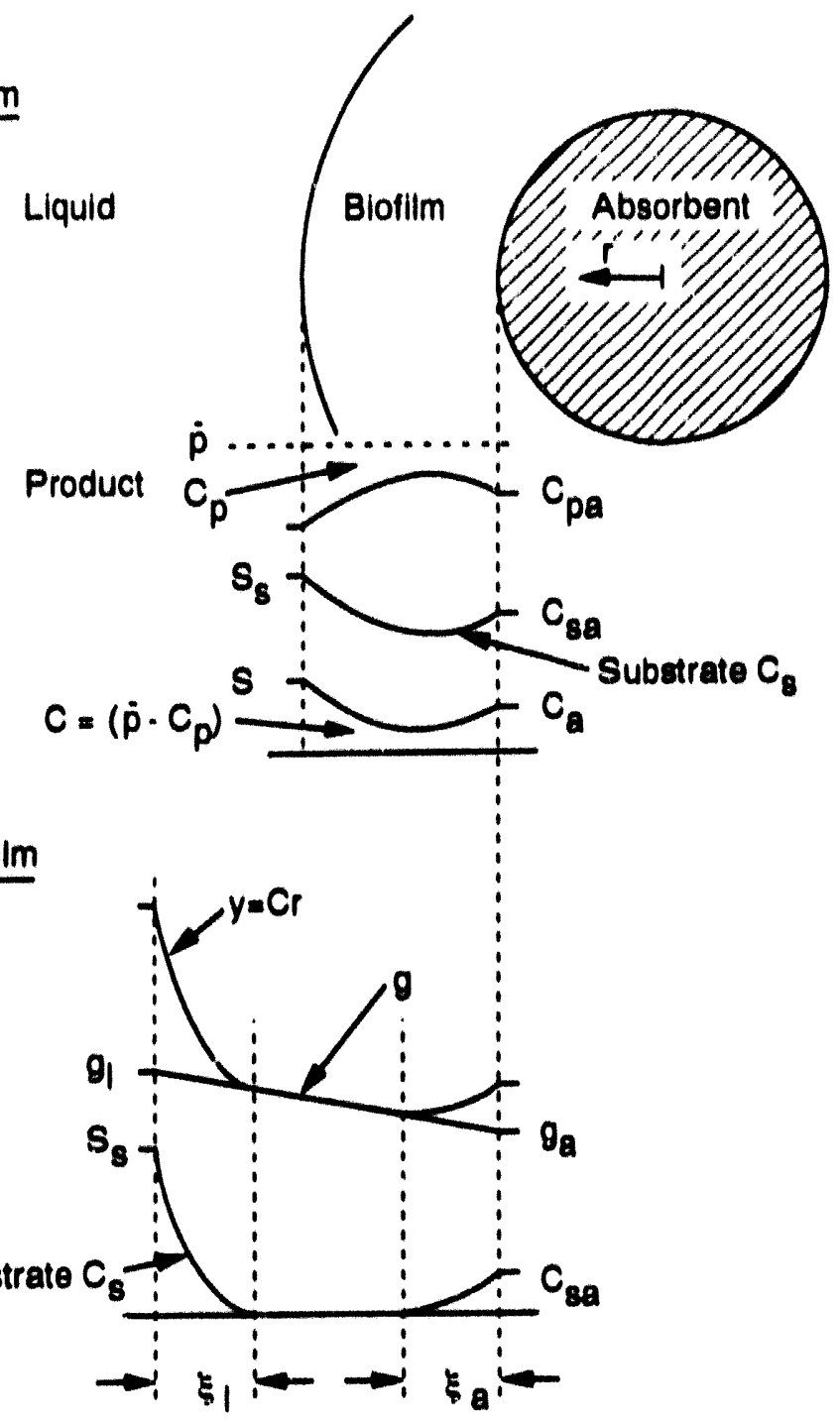

$$
\begin{aligned}
& \text { - Related to what limits motabolio activity } \\
& \text { (.) - Designates product innibitore } \\
& (+) \text { - Designatese eubotrate oxheustion limite metabolic activity } \\
& \dot{p} \text { - Completely inhibitory product concentration in liquid } \\
& r \text { - Distencos trom particle conter } \\
& \text { s- Component oonoentrations in liquid } \\
& \xi \text { - Active depth in a thick film }
\end{aligned}
$$

- Velue at absorbent eida of film - Component concentrallons in blomess I - Value af Lquid side of film p-Producl

- - Subetrato

Figure 36. Concentration profiles in the biofilm. 


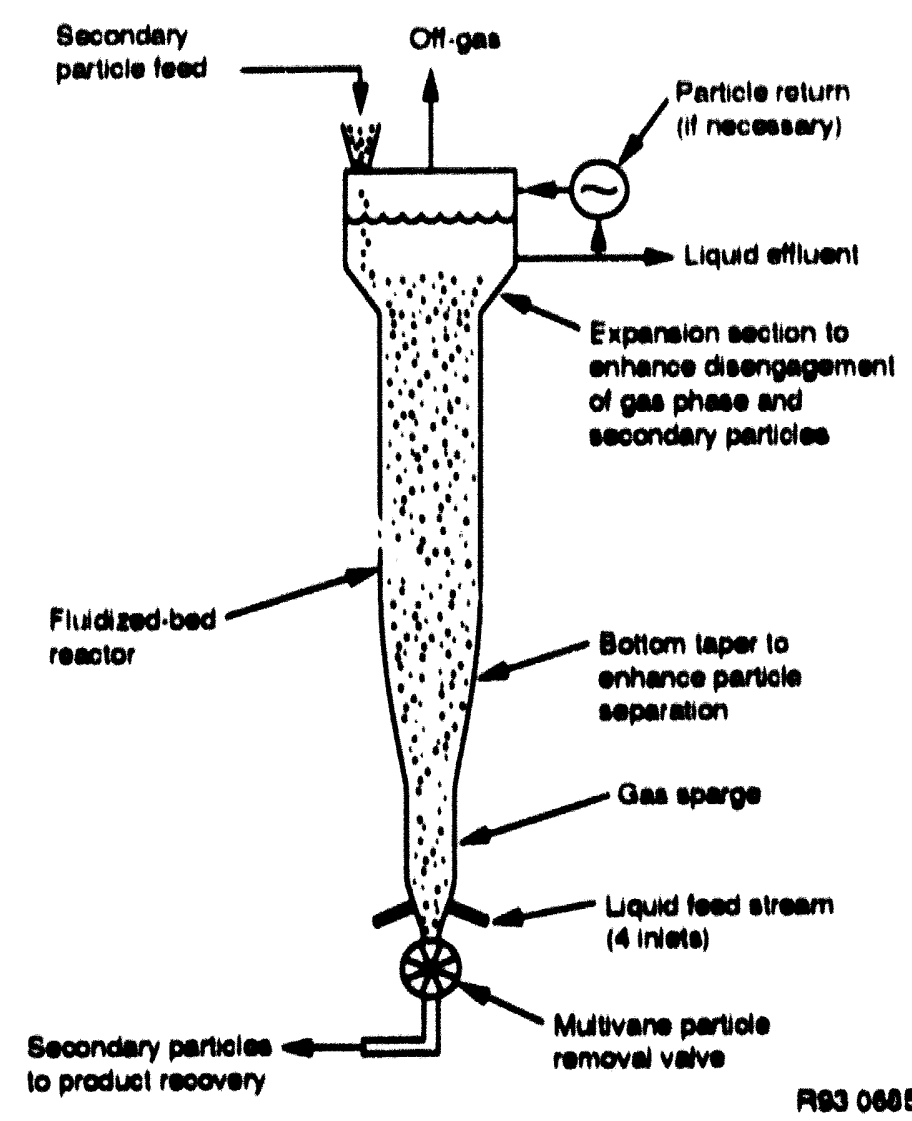

Figure 37. Schematic of experimental bipanicle fluidized-bed bioreacior operating in the countercurrenI mode.

Many authors have been successful in the physical recovery of desired compounds by using pervaporalion techniques. This method employs semipermeable membranes that allow for the removal of microbial hy-products but retains oher liquid constituents of the growth medium. Masawaki el al. th separaled the bioreacior feed. slock butanol from a mixlure of butanol-oleyl alcohol by using a poly(dimethylsiloxane) (PDMS) hollow fiber membrane (see Figure 38). This was accomplished at various temperatures, pressures, and butanol concentrations in the feed solution. The separation factor for butanol in the permeate $\mid\left(Y_{B}\right.$ (mole fraction) $)$ increased with increasing temperature and feed butanol concentrution $\mid\left(X_{B}\right.$ (mole fraction) $\mid$ (see Figure 39).
In reluted work, the Iransport of phenol from an aqueous solution to butyl acetate was more effi. cient with a membrane of cross-linked poly(4-vinylpyridine) when compured io polyeth. ylene, polypropylene, and polyletrafluoro-ethyl. ene 31 (see Tuble 9). Shubiai el ul." demonsiruted continuous cthanol production and separation by using un immobilized yeust in a continuous bio. reactor coupled with a pervaporation membrane. consisting of a $2 \mu \mathrm{m}$ polysiloxane composite on a polysulfone supporl (see Figure 4()). The combined system consisted of iwo recirculation loops for the medium inpul and for ethanol exit from the bioreactor to the pervaporation unit. This operation yielded a continuous ethanol production $(1,(X X) h)$ at a concentration of up $102(0 \%$ (wt/vol). 


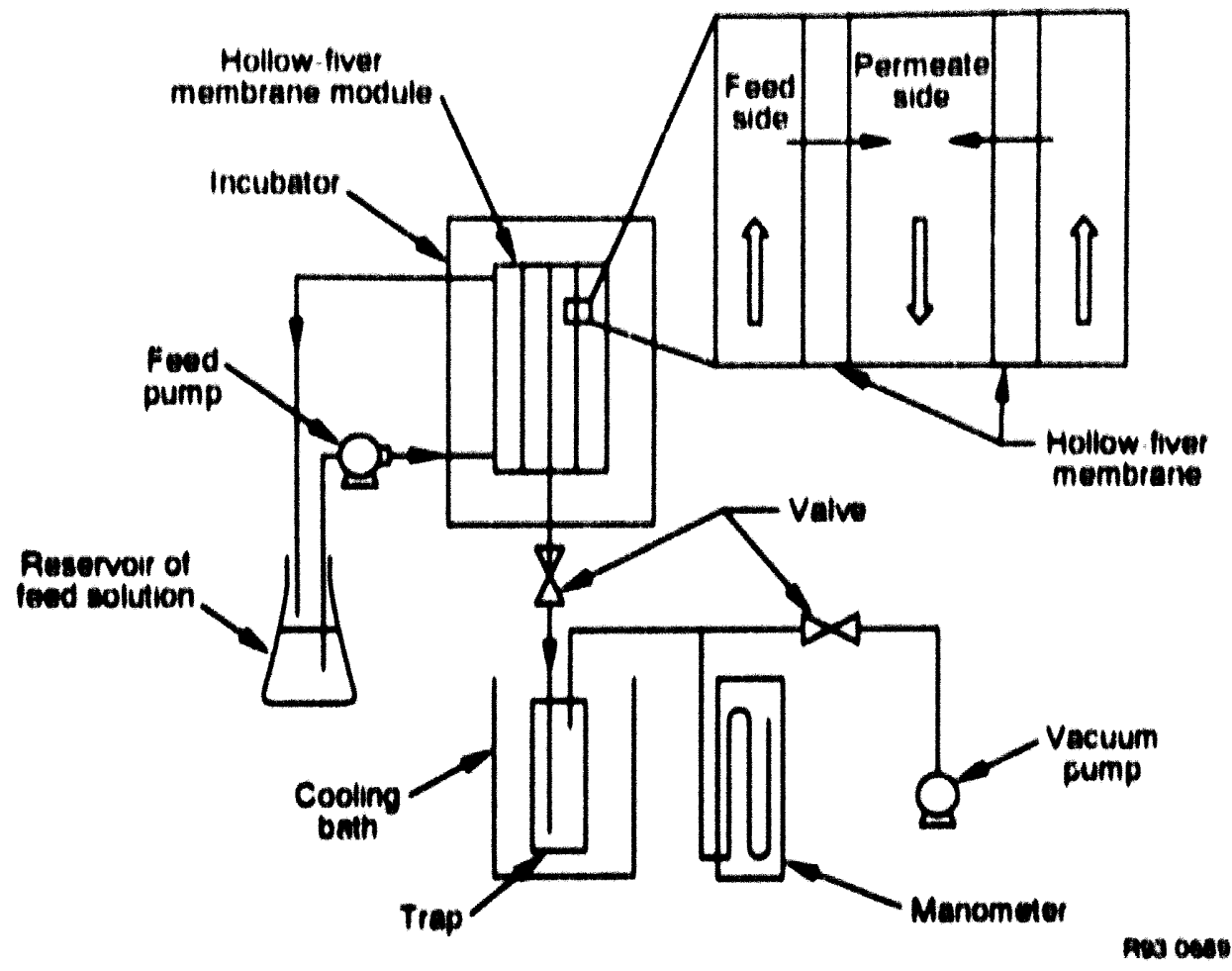

Figure 38. Schemalic diagram of apparalus for pervapuration hy hollow fiber moxlule.
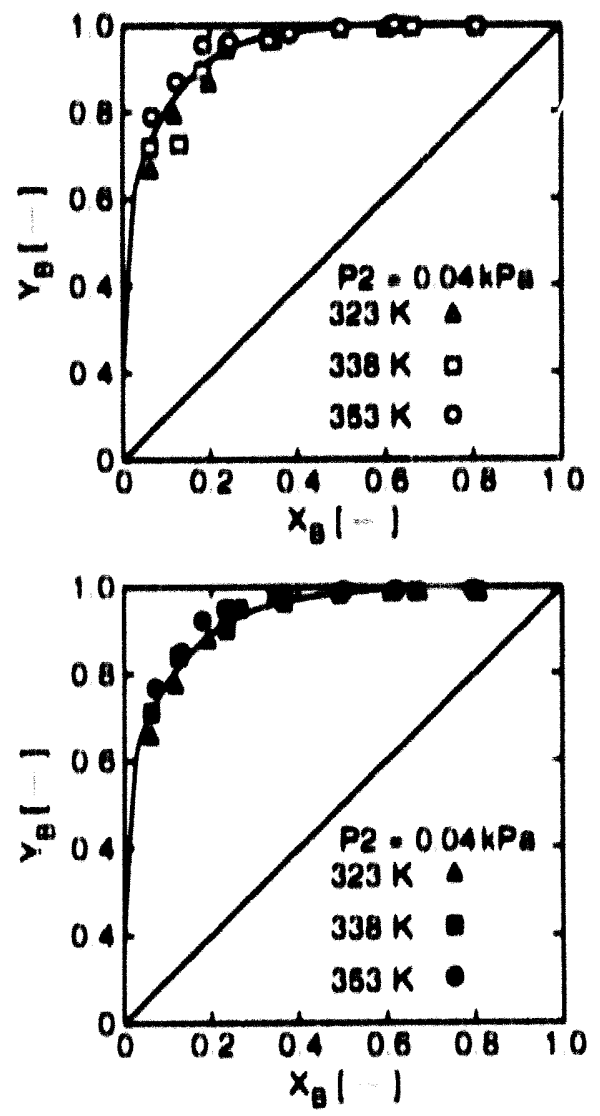

AD 0606

Figure 39. Relanon between mole fraction of hutanol in feed solulion and that in permetale solutions. 
Table 9. Permenhility of phenol through commercial membranes.

\begin{tabular}{|c|c|c|c|c|}
\hline Membrune & Poronily & $\begin{array}{l}\text { Pore dianileter } \\
\text { (IIIII) }\end{array}$ & $\begin{array}{c}\text { Thiskness } \\
\text { (IIII) }\end{array}$ & $\left.(10)^{p} \mathrm{~cm} / \mathrm{sec}\right)$ \\
\hline PVP & 0.90 & 11.06 & $2(x)$ & 2.22 \\
\hline $\mathbf{P E}$ & 0.50 & 0.118 & 2911 & 0.178 \\
\hline $\mathbf{P P}$ & $0.3 k$ & 11.112 & 25.1 & 1.112 \\
\hline PTFE & 11.57 & 11.1 & (N) & 10.47 \\
\hline
\end{tabular}

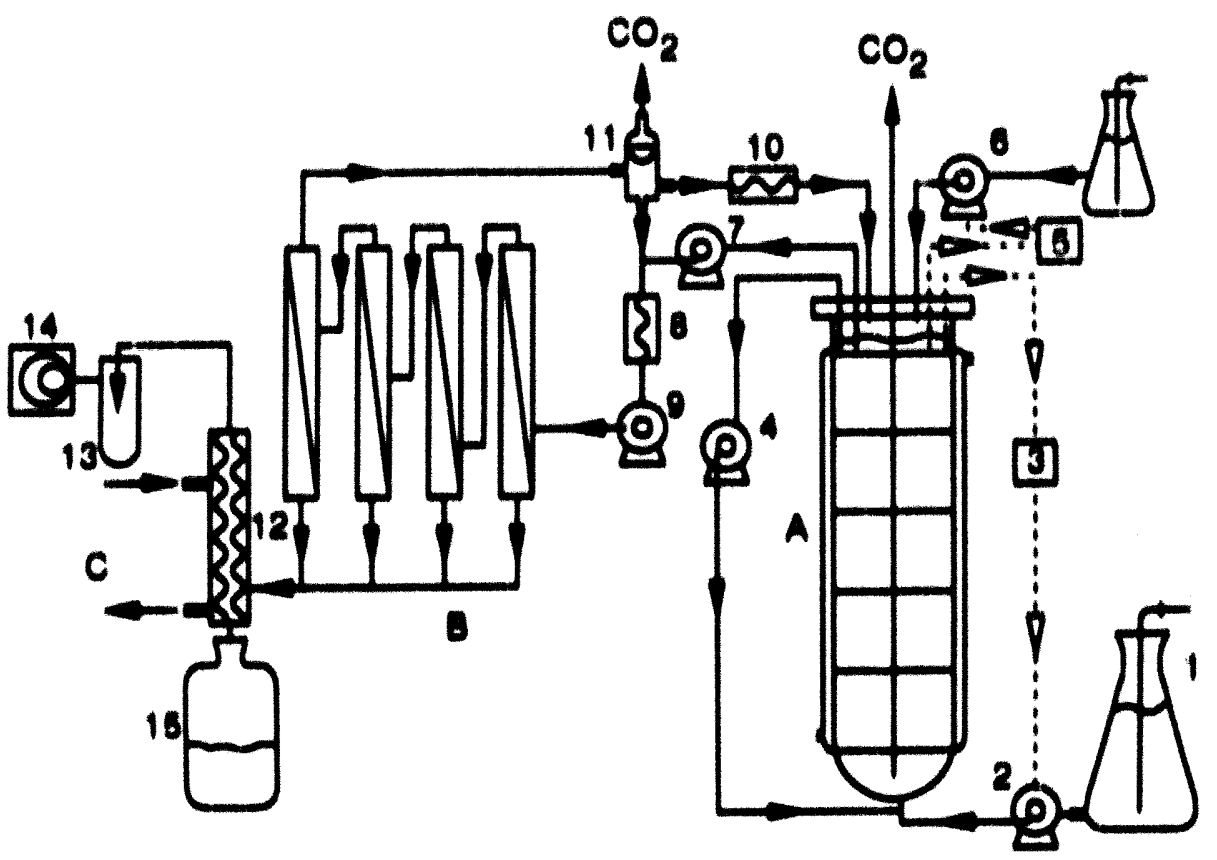

Sehemalic deasriplion of ine coupled oyetem
A $=$ immobilized yesel teactor
8 Membrane perveporation unil
C Product recovery uni

The concentreted sugat solution ie fed thom reservolt 1 by meens of the pertistelic pump? which is actuated by a level controller 3 The madium ineide ine reactor is circulated by means

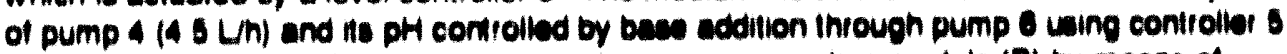
Fermanted modium is diven imo the mumbrane pervaporallon module (B) by moane of

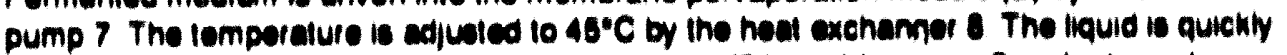
circulated over the uperream aide of the membrane $(9 \mathrm{Lmmin})$ by ump 8 and relurned gravitalionally $10 \mathrm{tho}$ resector enter cooling $1030^{\circ} \mathrm{C}$ by the heal or nanger 10 A floaning preseute reliet dovice 11 inataled in the oullet of ine membiane cliculating loop enabled inis medium return by preventing preseure bulldup and allowing the rolease of $\mathrm{CO}_{2}$ The downatream side of the mombrane is connected to the produet lecovery unit (C)

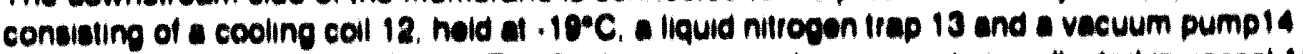
maintaning the vacuum a $30 \mathrm{mb}$ The inal concenirated pervaporate is collected in veseal 18

Figure 40. Schemalic dexcription of the coupled system. 
By-product removal using pervaporation. applied io acelone - butanol cllanol (ABE, pro. duction in Guidised bed heorecters may make this fermentalion process comomically viahle relative lo Iraditional lechnologies" The hio.

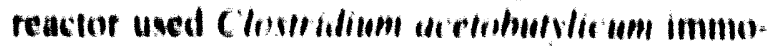
bilized onto honcshar with concentrated whey perneate, as the feedalick. Eflluenl from the hio. reactor was cycled through the pervaporalion chamber for hy aproduct removal and then cycled hack in the hioreactor (nee Figure 41 ). Silicone lubing with a wall thickness of $10.4 \mathrm{~mm}$ was used as the membranes in a pervaporallon shamber. localed downalream of the hioreaciot. Oxygen. free gas sweeping was used lo remove ABt from the membrane surface. ABE were condenned at -3 " $\mathrm{C}$

Grool el al: "semamined five methods for buta: nol removal and determined that pervaporation and liyuid-liyuid exiracition demonatrated greater potenitial than stripping. adsorpition, ot membrance solvent extraction. These findings are specific for one proxen bul can be uned lo demonutrale feani. hilily of removal strategien for similar fementa: llon lechnoloyies.

Cho and Shuler" developed a mullimembrane hioreactor incorporaliny pervaporalion and mem: brase wivent exiraction that consined of immo: bilied yeas sandwiched belween a hydrophobic membrane above and a hydrophilic membrane below isee ligute 42). The hydrophobic mem. hrane allowed for orygen iransport lo the cells and $\mathrm{CO}_{2}$ removal from the yolem. While the nutrient solution entered the cell layer throuph the hydrophilic membrane. ethanol extled the cell layer through the same membrane, Iraveled through the nuirient wolution stream and through anoilee hydrophohic membrane imon a solvent solution siream lor prosluct recovery This pro. cess required no exlemul energy hul was driven by the free enerky of the system.

Electrodialysis has been shown io he effective in the removal of L. lactale. 4.99 .96 .97 .94 acelic

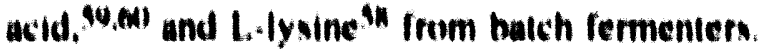
This process involves the removal of the disano: cialed end product from solulion uning electrodial. yols. This has been demonsirnied to reduce end product inhibition in batch fermentallons. The electrodialysis system consisted of platinum plates that served as anode and calhode wilh a current of 0.2-10.0 amperen. During electrodialy. ws. The fermentation broth ipll requlated at o.0 with $2 \mathrm{~N} \mathrm{NaOH}$ ) and anolyie (1) I $\left.\mathrm{N} \mathrm{H}_{2} \mathrm{SO}_{4}\right)$ were circulared through the syolem where the end prod. uct was coninuously exiracied hy the electrodia: lyzer and maintained at levels that decreased end proxfuci inhibition. (one drawback is thal cells con. caciling the dialywis membrane were killed This was avoided hy installing a microfilitalion module upatream of the elecirodialycer" (aee Plyure + t)

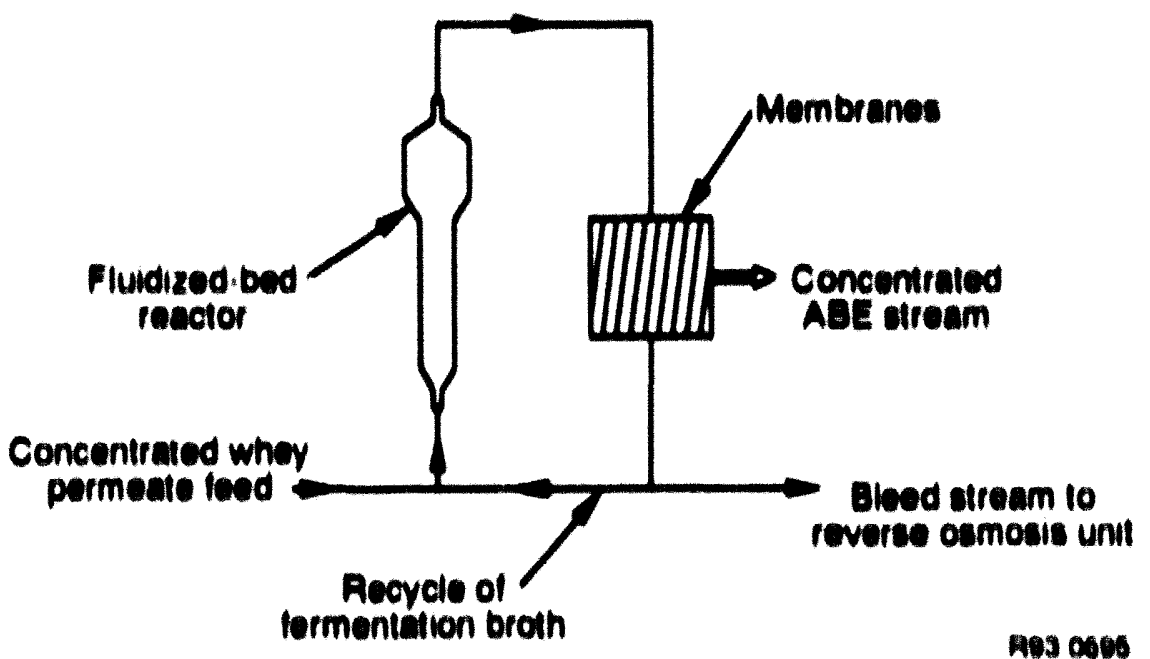

Floure 41. Schematic diagram of integrated continuous fermentalion/product removal for ABt: production. 


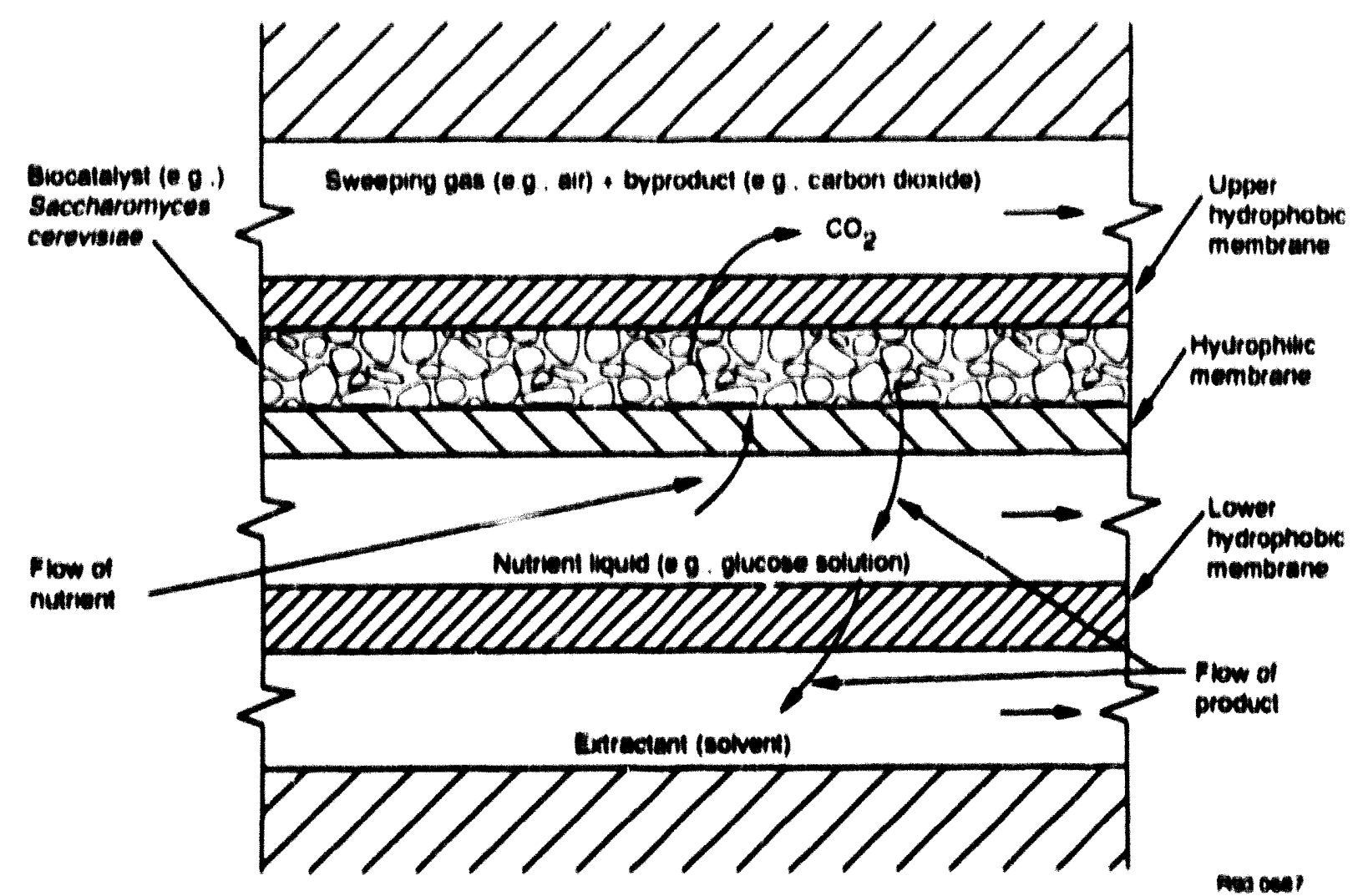

Figure 42. Example of mulilayer membrane hioreactor.

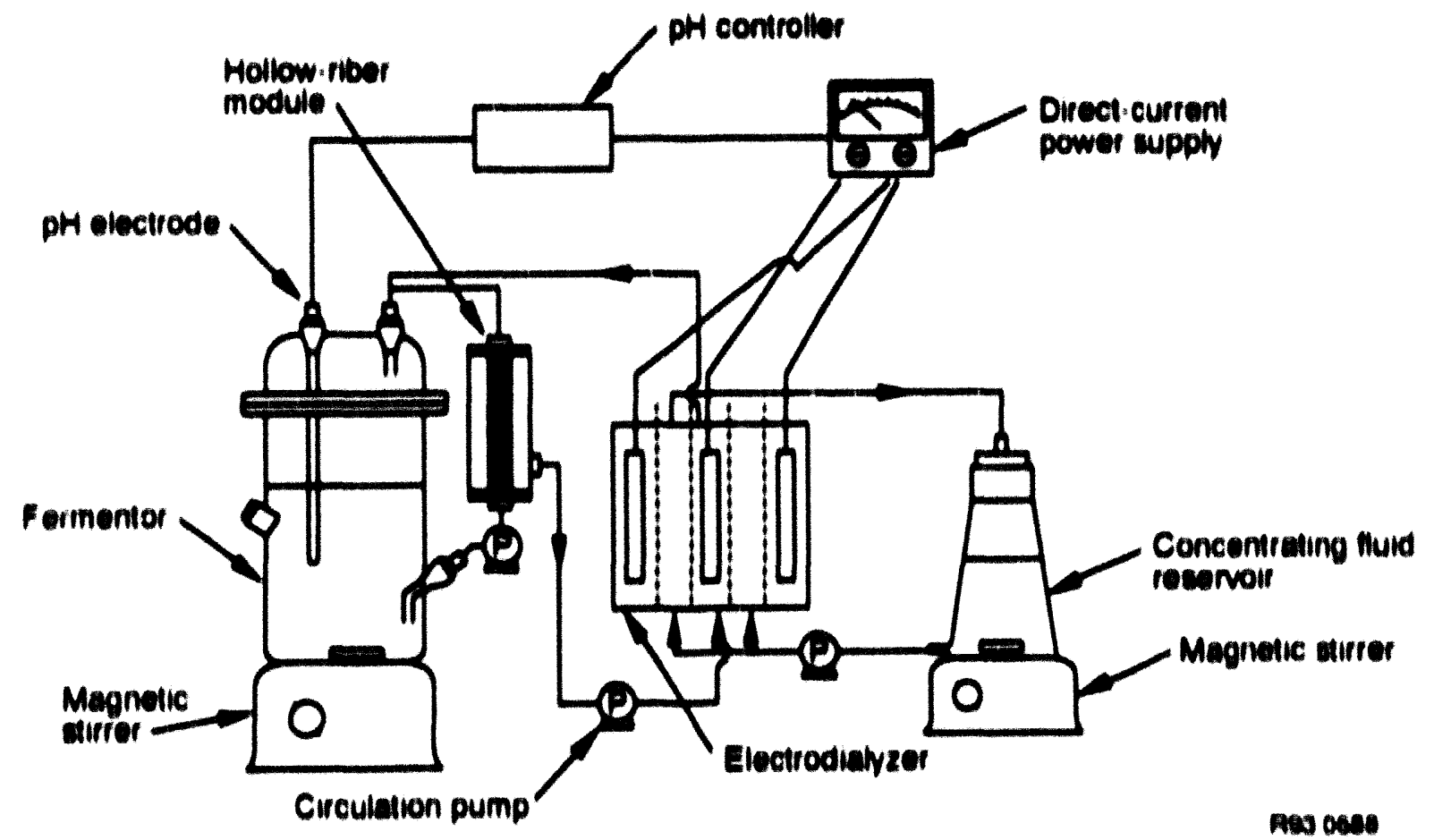

Figure 43. Sichemalic diayram of oynem for ED.F wilh an MF module 


\section{ELECTROCHEMICAL AND ELECTROLYTIC BIOREACTORS}

Miyawaki and Yanoth defined an clectroxhem. ical biofeacior as a "reacior in which an oxidore ductase reaction is conjugated with an electrochemical reaction at the electrode." The hioreactor consirucied by Miyawaki and Yanon"l consisted of a rolating graphile fod and disc onlos which phenazine melhosulfale (PMS) was adsorbed. The rod and disc were operaled inside $2(X) \mathrm{mL}$ of a $(0.1 \mathrm{M}$ phosphate buffer with oxyen removed by bubbling high purily nilrogen gas through the liquid. The hioreaciof was connected to a conventional three electrode system con. irolled hy a potenilastat. Cyclic voliammeiry measurements were used lo determine the elec: Irochemical oxidalion of NADH (see Figure 44) and were oblained using function generalor to produce a polential sweep wignal. This bioreaciof allowed for the regeneration of NAD* 10 NADH hy using the encyme nywem GoPDH with adworbed PMS i we Figure 4s) lo act as a medialor reducing the cendency of high overpolential in NAD* repeneralion for the reactions in Figure th.
This hioreaclor design has polential for use wilh immobilised ensymes for hiosensors, hiohydro. metallurgy, and hiochemical transformations.

Yunker and Radovich ${ }^{\text {2 }}$ developed an electro. lylic fermentation process for enhancing the urowith and increasing cell density of Thiolusil. lius ferrousiduns hy regeneraling ferrous ions ued by the cell us an energy source. The lertous lons are regeneruled hy reducing the ferric lons at the cuthode hy passing a current through the fer. mentation medium. This method increased bacte. rial densily in the hioreactor hy minimizing the inhibitory effecin on cell growth hy ferric lons as well un minimizing limilations caused hy sub. strate depletion. Current from 230 1 1,000) ma inrough the hioreaclor resulied in increased growith and cell densily as measured hy cell pro. rein. Electrolyzed cells also demonsirated a shorter generalion lime compared lo conirol cells. Techniques such as this can aswist in obluining high cell densilies of orgunisms where obther methods have proved inudequale.

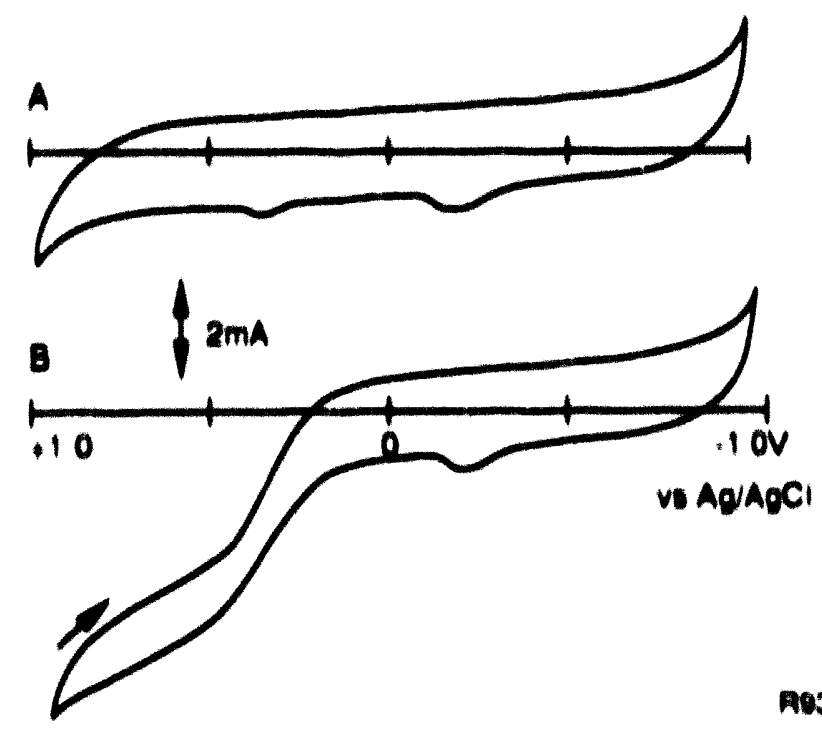

903 0060

Figure 44. Cyclic vollammogram of electrochemical oxidation of NADH in an olecirochemical horeacior. 


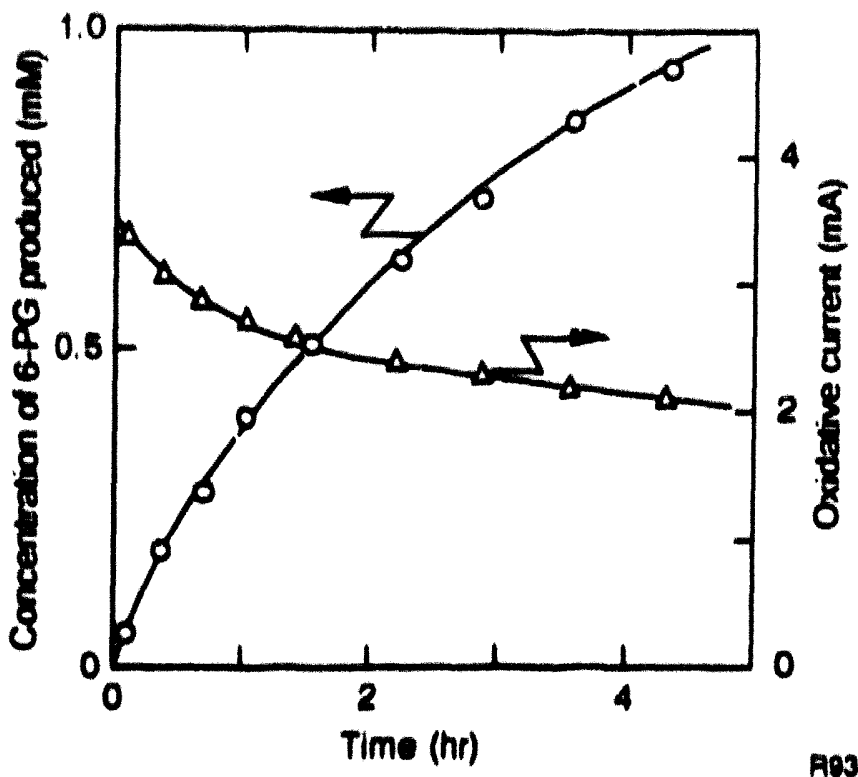

A93 0001

Floure 48. CinPDH reaction conjugated with constant potential.

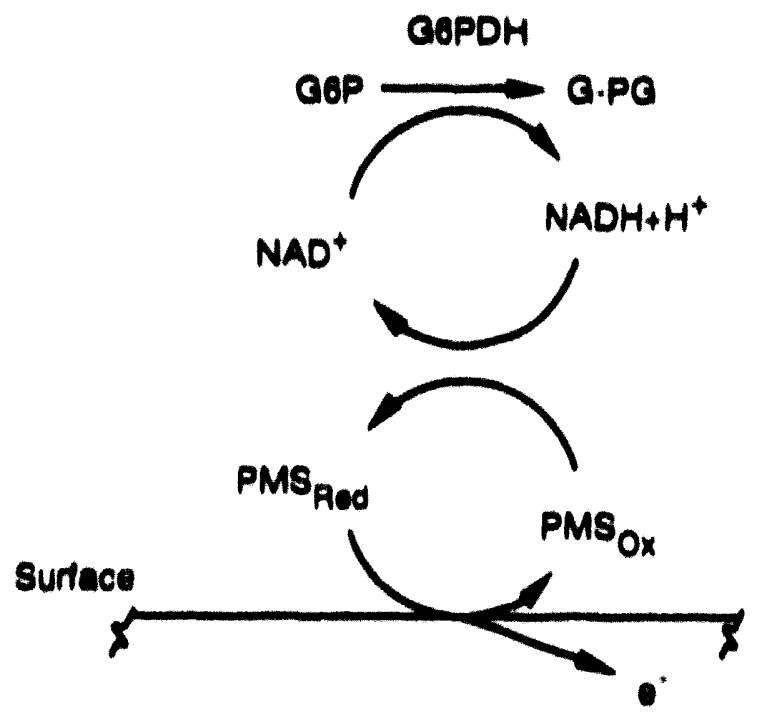

R00 0007

Fleure 46. NAD regeneralion syslem by G6PDH in an elecirochemical bioreacior. 


\section{FUTURE AREAS OF STUDY}

Bioreactor designs and bioprocessing strategies reported here should provide a bases for continued developments and improvements of bioprocesses in future work. Specific areas of rescarch that may provide the most potential in improving the economic potential of biotechnology include advanced by-product separation procedures, simplified bioreactor designs capable of economically increasing gas and liquid mass transfer, improved cell and enzyme immobilization techniques, and electrochemical bioprocesses.
The economic potential of individual bioprocessen will also increase if they are designed 10 serve multiple purposes such as bioremediation and hy-product production. An example would be methane bioconversion to methanol, single cell protein or both, all incorporated in one bioprocess. In this way the cost of a bioprocess designed for bioremediation could be offset by the simultaneous bioconversion of a particular waste to a marketable product. 


\section{REFERENCES}

I. K. T. Klasson. M. D. Ackerson, E. C. Clausen, and J. L. Gaddy, "Mass-Transporn in Bioreaciors for Coal Synthesis Gas Fermentation," Fucl, 122(14, 1992, p.125.

2. K. T. Klasson. M. D. Ackerson, E. C. Clausen, and J. L. Gaddy. "Biological Conversion of Synthesis Gas Into Fuels," International Journal of Hydrogen Energy. V17. N4, 1992, pp. 281-288.

3. H. Brauer, "Growth of Fungi and Bacteria in the Reciprocating Jet Bioreactor," Binprocess Engineering. 6, 1991, pp. 1-15.

4. H. Brauer and A. P. Annachhatre, "Waste-Water Nitrification Kinetics Using Reciprocuting Jet Bioreactor," Bioprocess Engineering, V7, N6 (MAR), 1992. pp. 277-286.

5. W. Grueger and H. Brauer, Verfahrenstechnische Untersuchung der Abwasserreinigung im Hubstruhl. reaktor. VDI-Forschungsheft 643. VDI-Verlag GmbH. Dusseldorf, 1987.

6. Y. Shi, D. D. Y. Ryu, and S. H. Park, "Performance of Mammalian Cell Culture Bioreactor with a New Impeller Design," Biotechnology and Bioengineering, 40, 1992, pp. 260-270.

7. M. Reiter, F. Weigang, W. Ernst, and H. W. D. Katinger, "High Density Microcurrier Culture with a New Device which allows Oxygenation and Perfusion of Microcarrier Cultures," Cyotechmology, 3. 1990, pp. 39-42.

8. T. Ahmed and M. J. Semmens, "Use of Sealed End Hollow Fibers for Bubbleless Membrune Aeration: Experimental Studies," Journal of Membrane Science, 69, 1992, pp. 1-10.

9. O. Hirasa, H. Ichijo, and A. Yamauchi, "Oxygen Transfer from Silicone Hollow Fiber Membrune Io Water," Journal of Fermentation and Bioengineering, 71, 1991, pp. 2(16-207.

10. S. Beeton, H. R. Millward, B. J. Bellhouse, A. M. Nicholson, N. Jenkins, and C. J. Knowles, "Gas Transfer Characteristics of a Novel Membrane Bioreactor, Biotechnology and Bionengineering. V.38. NI0, 1991, pp. 1.233-1.238.

11. W. T. Wu, J. Y. Wu, and J. Z. Jong. "Mass Transfer in an Airlift Reactor with a Net Draft Tube," Bio. rechnolog! Progress, 8. 1992. pp. 465-468.

12. H. S. Jee, N. Nishio, and S. Nagai, " $\mathrm{CH}_{4}$ Production from $\mathrm{H}_{2}$ and $\mathrm{CO}_{2}$ by Methanohacterium thermo. autorrophicum Cells Fixed on Hollow Fibers," Biotechnology Letrers, I0, 1988, pp. 24.3-248.

13. T. Yano, K. Aoki, and S. Nagai, "Kinetics of $\mathrm{CH}_{4}$ Production from $\mathrm{H}_{2}$ and $\mathrm{CO}_{2}$ in a Hollow Fiber Reactor by Plug Flow Reaction Model," Journal of Fermentation and Bioenginecering. 71, 1991, pp. 203-205.

14. W. A. Apel, P. R. Dugan, and M. R. Wiebe. "Influence of Kaolin on Methune Oxidation hy Methyle. monas methanica in Gas Phase Bioreactors," Fuel, 71, 1992, pp, 80.5-808.

15. W. A. Apel, P. R. Dugan, and M. R. Wiebe. "Use of Methanotrophic Bacteria in Gas Phase Bioreuctors to Abate Methane in Coal Mine Almospheres," Fucl, 70, 1991, pp. 1,(0)1-1,(X)3.

16. M. A. Applegate and G. Stephanopoulos, "Development of a Single-Pass Ceramic Matrix Bioreactor for Large-Scale Mammalian Cell Culture," Biotechnology and Bionengineering. 40. 1992. pp. $1.056-1,068$. 
17. C. M. Nelson, M. R. Schuppenhauer, and D. S. Clark, "High-Pressure, High-Temperature Bioreactor for Comparing Effects of Hyperbaric and Hydrostatic Pressure on Bacterial Growth," Applied and Environmental Microbiology, 58, 1992, pp. 1,789-1,793.

18. M. Torrijos, Evaluation des techniques non conventionnelles d'intensification des transfers d'oxygène en fermentation, Thèse Docteur Ingénier I.N.S.A., Toulouse, France, 1987.

19. P. Adlercreutz and B. Mattiasson, "Oxygen Supply to Immobilized Cells," European Journal of Applied Microbiology and Biotechnology, 16, 1982, pp. 165-170.

20. C. Khosla and J. Bailey, Technical Support Package on: More Genetic Engineering with Cloned Hemoglobin Genes," NASA Tech Brief Vol. 16, No. 11, Item \#94 from JPL New Technology Report NPO-18156-7669, 1992.

21. J. L. Rols and G. GOMA, "Enhancement of Oxygen-Transfer Rates in Fermentation Using OxygenVectors," Biotechnology Advances, V7, 1989, pp. 1-14.

22. A. T. King, B. J. Mulligan, and K. C. Lowe, "Perfluorochemicals and Cell Culture," Biotechnology, 7, 1989, pp. 1,037-1,042.

23. D. Damiano and S. S. Wang, "Novel Use of a Perfluorocarbon for Supplying Oxygen to Aerobic Submerged Cultures," Biotechnology Letters, 7, 1985, pp. 81-86.

24. L. K. Ju, J. F. Lee, and W. B. Armiger, "Enhancing Oxygen-Transfer in Bioreactors by Perfluorocarbon Emulsions," Biotechnology Progress, V7, N4, 1991, pp. 323-329.

25. Ceschin, C., M.C. Malet-Martino, G. Michel and A. Lattes. 1985. C.R. Acad. Sc. Paris, Ser.III 18, pp. 669-672.

26. R. H. Douglass, J. M. Armstrong, and W.M. Korreck Design of a Packed Column Bioreactor for onSite Treatment of Air Stripper Off Gas On-Site Bioreclamation (1991) pp. 209-225, eds. R. F. Hinchee and R. F. Olfenbuttel, Publisher Butterwood-Heinemann.

27. T. O. Williams and F. C. Miller, "Biofilters and Facility Operations," BioCycle, 1992, pp. 75-79.

28. R. S. Tiwaree, K. S. Cho, M. Hirai, and M. Shoda, "Biological Deodorization of Dimethyl Sulfide Using Different Fabrics as the Carriers of Microorganisms," Applied Biochemistry and Biotechnology, 32,1992 , pp. 135-148.

29. S. K. Lee and M. Shoda, "Biological Deoderization Using Activated Carbon Fabric as a Carrier of Microorganisms," Journal of Fermentation and Bioengineering, 68, 437, 1989.

30. G. E. Speitel and J. M. Leonard, "A Sequencing Biofilm Reactor for the Treatment of Chlorinated Solvents Using Methanotrophs," Water Environment Research, 64, 1992, pp. 712-719.

31. V. P. Lewis and S. T. Yang, "Continuous Propionic Acid Fermentation by Immobilized Propionibacterium acidipropionici in a Novel Packed-Bed Bioreactor," Biotechnology and Bioengineering, 40, 1992, pp. 465-474.

32. N. Nishio, E. Kayawake, and S. Nagai, "Rapid Methane Production from Formate or Acetate in Fixed Bed Bioreactors," Journal of Fermentation Technology, 63, 1985, pp. 205-209. 
33. C. J. Yee, Y. Hsu, and W. K. Shieh, "Effects of Microcarrier Pore Characteristics on Methanogenic Fluidized Bed Performance," Water Research 26, 1992, pp. 1,119-1,125.

34. T. J. Harrington, J. L. Gainer, and D. J. Kirwan, "Ceramic Membrane Microfilter as an Immobilized Enzyme Reactor," Enzyme Microbial Technology, 14, 1992, pp. 813-818.

35. B. R. Pieters, G. Bardeletti, and P. R. Coulet, "Glucoamylase Immobilization on a Magnetic Microparticle for the Continuous Hydrolysis of Maltodextrin in a Fluidized Bed Reactor," Applied Biochemistry and Biotechnology, 32, 1992, pp. 37-53.

36. L. Backer, S. Devleminck, R. Willaert, and G. Baron, "Reaction and Diffusion in a Gel Membrane Reactor Containing Immobilized Cells," Biotechnology and Bioengineering, 40, 1992, pp. 322-328.

37. Y. K. Lee and C. S. Low, "Effect of Photobioreactor Inclination on the Biomass Productivity of an Outdoor Algal Culture," Biotechnology and Bioengineering, 38, 1991, pp. 995-1,000.

38. H. Takano, H. Takeyama, N. Nakamura, K. Sode, J. G. Burgess, E. Manabe, M. Hirano, and T. Matsunaga, " $\mathrm{CO}_{2}$ Removal by High-Density Culture of a Marine Cyanobacterium Synechococcus sp. Using an Improved Photobioreactor Employing Light-Diffusing Optical Fibers," Applied Biochemistry and Biotechnology 34, 1992, pp. 449-458.

39. M. Famiglietti, A. Hochkoppler, E. Wehrli, and P. L. Luisi, "Photosynthetic Activity of Cyanobacteria in Water-in-Oil Microemulsions," Biotechnology and Bioengineering, 40, 1992, pp. 173-178.

40. M. M. T. Kahn, M. R. Adiga, and J. P. Bhatt, "Large Scale Photobiological Solar Hydrogen Generation Using Halobacterium Halobium $\mathrm{MMT}_{22}$ and Silicon Cell," Journal of Hydrogen Energy, 17, 1992, pp. 93-95.

41. J. A. Field, M. J. H. Leyendeckers, R. Sierra-Alvarez, G. Lettinga, and L. A. A. Habets, "The Methanogenic Toxicity of Bark Tannins and the Anaerobic Biodegradability of Water Soluble Bark Matter," Water Science and Technology, 20, 1, 1988, pp. 219-240.

42. A. Cohen, "Effects of Some Industrial Chemirals on Anaerobic Activity Measured by Sequential Automated Methanometry (SAM)," Water Science and Technology, 25, 1992, pp. 11-20.

43. R. Thatipamala, S. Rohani, and G. A. Hill, "Effects of High Product and Substrate Inhibitions on the Kinetics and Biomass and Product Yields during Ethanol Batch Fermentation," Biotechnology and Bioengineering, 40, 1992, pp. 289-297.

44. G. F. Payne, W. Q. Sun, and A. Sohrabi, "Tyrosinase Reaction/Chitosan Adsorption for Selectively Removing Phenols from Aqueous Mixtures," Biotechnology and Bioengineering, 40, 1992 , pp. $1,011-1,018$.

45. J. W. Groot, R.G. J. M. Vanderlans, and K. C. A. M. Luyben, "Technologies for Butanol Recovery Integrated with Fermentations," Process Biochemistry 27, 2, 1992, pp. 61-75.

46. N. B. Milestone and D. M. Bibby, Journal of Chemical Technology and Biotechnology, 31, 1981, p. 1.

47. G. F. Andrews and J. P. Fonta, "A Novel Adsorbing Bioreactor," Biotechnology' and Bioengineering Symposium, No. 17, 1986, pp. 317-333. 


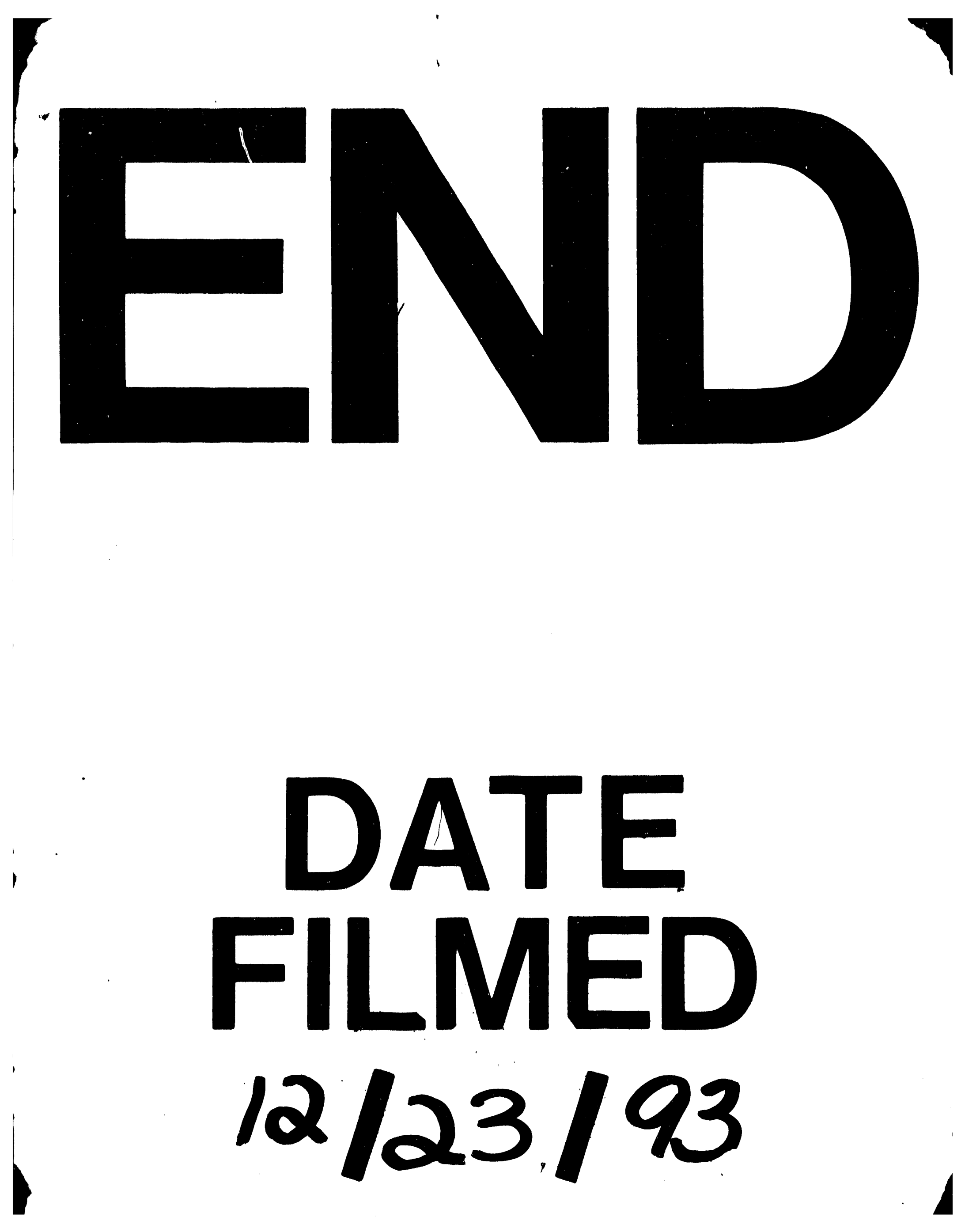


